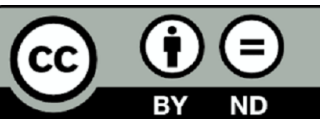

Michał Tomasz Wójciuk

Lublin-Warszawa

\title{
Zjawiska atmosferyczne, elementy meteorologiczne i klęski żywiołowe na Litwie w latach 1697-1763 w wybranych źródłach narracyjnych
}

\begin{abstract}
Zarys treści
Artykuł omawia problematykę zjawisk meteorologicznych i stanowiących ich konsekwencję zjawisk hydrologicznych oraz klęsk żywiołowych na terytorium Wielkiego Księstwa Litewskiego w latach 1697-1763 przez pryzmat źródeł narracyjnych. Przedstawiona została problematyka życia codziennego $\mathrm{w}$ aspekcie zjawisk pogodowych, a także sposoby ich nazewnictwa. Oprócz tego omówiono klęski żywiołowe dotykające Litwę w omawianej epoce: powodzie, głód, pożary, inwazje szarańczy, epidemie chorób zakaźnych. Zwrócono uwagę na postrzeganie niecodziennych zjawisk naturalnych i wiążące się z tym implikacje mentalnościowe. W źródłach odnotowywano wszelkie warunki „niecodzienne” stanowiące przykład „osobliwości” bądź też uznane za anomalie. Przebadane wzmianki dotyczą przede wszystkim spostrzeżeń zarejestrowanych w czasie podróży lub też stanowią doniesienia o warunkach umożliwiających bądź utrudniających przemieszczanie się czy też spędzanie czasu wolnego. Pewna część odnalezionych wzmianek odnosi się również bezpośrednio do problematyki gospodarczej.
\end{abstract}

Słowa klucze: zjawiska atmosferyczne, meteorologia, klęski żywiołowe, życie codzienne, Litwa Keywords: Atmospheric phenomena, meteorology, natural disasters, everyday life, Lithuania

Sytuacja pogodowa na Litwie w I połowie XVIII w. ${ }^{1}$ nie była do tej pory przedmiotem szczegółowych badań naukowych ${ }^{2}$. Natomiast tematyka zarówno

\footnotetext{
${ }^{1}$ Temat artykułu jest związany z realizowanym przeze mnie projektem badawczym pt. Człowiek wobec zjawisk naturalnych, fenomenów przyrodniczych i klęsk żywiołowych $w$ Rzeczypospolitej $w$ latach 1697-1763. Cel pracy to przedstawienie postaw człowieka wobec zjawisk naturalnych, a także uchwycenie kontekstu kulturowego, mentalnego, duchowego oraz emocjonalnego $\mathrm{w}$ aspekcie indywidualnej i społecznej percepcji zjawisk przyrodniczych oraz klęsk żywiołowych; przedmiotem badań objąłem zgodnie z koncepcją Władysława Semkowicza (Zagadnienie klimatu w czasach historycznych, „Przegląd Geograficzny” 1922 [1923], t. 3, s. 22) zjawi-
} 
klęsk żywiołowych ${ }^{3}$, jak również zjawisk przyrodniczych w czasach wczesnonowożytnych ${ }^{4}$ znalazła szerokie odzwierciedlenie w historiografii. Mając świado-

ska: meteorologiczne, telluryczne, astronomiczne, hydrologiczne, florystyczne, zoologiczne, antropogeograficzne.

2 Zagadnieniem interesował się Franciszek Jukniewicz, w swoim eseju wspomniał zjawiska na Litwie - wylewy wiosenne i powodzie: 1699, 1701, 1714, 1716, 1736, 1740, gradobicia: 1699, 1703, 1713, 1729, 1731, szarańcza: 1711, 1736, 1748, nieurodzaje: 1706, 1709, 1715, 1716, 1718, głód: $1697,1702,1708,1710,1715,1718$, epidemie: 1707-1711, 1717, 1730, autor wyliczył też urodzajne lata: $1711,1713,1734,1736$. F. Jukniewicz, Zjawiska meteorologiczne i stan urodzajów oraz pomory w Polsce w latach 1697-1750, „Sprawozdania Towarzystwa Naukowego we Lwowie”, R. 17, 1937 [1939], z. 1, s. 63-70.

${ }^{3}$ Szczegółowe badania nad zjawiskami meteorologicznymi występującymi na ziemiach Polski w epoce nowożytnej (w tym również nad klęskami żywiołowymi) zainicjował w dwudziestoleciu międzywojennym prof. Franciszek Bujak, kierownik Zakładu Historii Społecznej i Gospodarczej Wydziału Humanistycznego Uniwersytetu Jana Kazimierza we Lwowie (problematyka ta znalazła się również w kręgu zainteresowań mediewistów). Owocem studiów badaczy dziejów wczesnonowożytnych były opublikowane Kroniki klęsk elementarnych pióra historyków gospodarki: Antoniego Walawendera (Kronika klęsk elementarnych $w$ Polsce $i w$ krajach sąsiednich $w$ latach 1450-1586, t. 1: Zjawiska meteorologiczne i pomory (z wykresami), Lwów 1932) oraz Stanisławy Namaczyńskiej (Kronika klęsk elementarnych $w$ Polsce $i w$ krajach sąsiednich $w$ latach 1648-1696, t. 1: Zjawiska meteorologiczne i pomory, Lwów 1937). Współcześnie zagadnieniem katastrof przyrodniczych w omawianej epoce interesowali się Stanisław Hoszowski (Klęski elementarne w Polsce w latach 1587-1648, w: Prace z dziejów Polski feudalnej ofiarowane Romanowi Grodeckiemu w 70 rocznicę urodzin, red. Z. Budkowa i in., Warszawa 1960, s. 453-465), Wojciech Sołtys (Klęski elementarne $w$ ziemi sanockiej $w$ XVII w. i ich wplyw na życie mieszkańców, „Materiały Muzeum Budownictwa Ludowego w Sanoku" 1984, nr 28, s. 56-75), Jerzy Motylewicz (Straty i zniszczenia wojenne oraz klęski elementarne $w$ miastach ziemi przemyskiej i sanockiej $w$ pierwszej połowie XVIII wieku, „Studia Przemyskie” 1993, t. 1, s. 71-84), Joanna Partyka (Szlachecka silva rerum jako źródło do badań etnograficznych, „Etnografia Polska” 1988, t. 32, z. 2, s. 67-91), Tadeusz Srogosz (Staropolskie postrzeganie klęsk elementarnych, w: Staropolski ogląd świata: materiały z konferencji, Wrocław 23-24 października 2004 r., red. B. Rok, F. Wolański, Wrocław 2004, s. 151-158), Jacek Bazak (Klęski elementarne w życiu Jarosławia i okolic $w$ XVII i pierwszej połowie XVIII wieku, „Rocznik Stowarzyszenia Miłośników Jarosławia” 2002-2004, t. 15, s. 47-70), Andrzej Karpiński (Biedota miejska wobec zaraz i innych klęsk żywiołowych $w$ Warszawie w latach 1526-1655, „Rocznik Warszawski” 1981, t. 16, s. 81-121; W walce z niewidzialnym wrogiem. Epidemie chorób zakaźnych w Rzeczypospolitej w XVI-XVIII wieku i ich następstwa demograficzne, społeczno-ekonomiczne i polityczne, Warszawa 2000), Mirosław Gilarski (Łowce - parafie, rozwój gospodarczy oraz najazdy nieprzyjacielskie i klęski żywiołowe do 1772 roku, „Rocznik Historyczno-Archiwalny” 2000, t. 14, s. 21-61), Agata Roćko (Rzeczpospolita czasów saskich w pamiętniku Krzysztofa Zawiszy - świat wojen, żywiołów, niepokojów, „Napis” 2001, seria VII, s. 313-321), Cezary Kuklo (Demografia Rzeczypospolitej przedrozbiorowej, Warszawa 2009, s. 249-257), Maurycy Zajęcki (Instrumenty prawne ochrony przeciwpożarowej w miastach Polski przedrozbiorowej, Poznań 2014). Na uwagę zasługują dwie prace zbiorowe: jeden z tomów Między barokiem a oświeceniem pod red. Krystyny Stasiewicz i Stanisława Achremczyka (Między barokiem a oświeceniem. Wojny i niepokoje czasów saskich, red. K. Stasiewicz, S. Achremczyk, Olsztyn 2004), a zwłaszcza artykuły: Joanny Partyki (Gazetki seryjne i silvae rerum jako źródło wiedzy o niepokojach czasów saskich, s. 116121), Bogdana Roka (Duszpasterstwo czasów trwogi, wojny i zarazy. Z dziejów Kościoła katolickiego w czasach saskich, s. 107-115) oraz publikacja pod red. Tomasza Głowińskiego i Elżbiety Kościk 
mość braku możliwości omówienia całego wieloaspektowego zasobu źródłowego, świadomie ograniczyłem się tylko do niektórych źródeł. W moich rozważaniach posłużyłem się pamiętnikami, diariuszami, kronikami i listami, których autorami byli reprezentanci: magnaterii ${ }^{5}$, szlachty ${ }^{6}$, duchowieństwa (zakonnego i diecezjalnego $)^{7}$, mieszczaństwa (patrycjatu) ${ }^{8}$. Uwzględniłem również diariusze z podróży obcokrajowców pióra stolnika Piotra Andrejewicza Tołstoja (1697-1699) i Wilhelma

(Od powietrza, głodu, ognia i wojny... Klęski elementarne na przestrzeni wieków, red. T. Głowiński, E. Kościk, Wrocław 2013), a przede wszystkim artykuły: Piotra Miodunki (Staropolskie ksiegi metrykalne jako źródło do badania klęsk elementarnych, s. 41-57), Teresy Bogacz (Dawne klęski elementarne na Ślasku w przekazie artystycznym, s. 59-68), Piotra Badyny (Faunistyczne przyczyny klęsk elementarnych $w$ oczach wybranych pisarzy XVII i XVIII stulecia, s. 69-83). W latach 2005-2008 pod przewodnictwem kierownika Zakładu Historii Gospodarczej, Demografii i Statystyki Uniwersytetu Wrocławskiego, prof. Elżbiety Kościk był prowadzony projekt badawczy Klęski elementarne na ziemiach polskich do końca XVIII w. W 2013 r. pod jej redakcją ukazała się praca zbiorowa pt. Gdy nadciagała wielka woda. Klęski powodzi na ziemiach polskich (Wrocław). Artykuły zebrane w pracy w niewielkim stopniu dotykają zagadnień interesującej nas epoki, można jedynie przytoczyć opracowanie Rościsława Żerelika (Powodzie w powiecie średzkim od XVIII $w$. do 1945 roku, w: Gdy nadciagała wielka woda..., s. 73-82).

${ }^{4}$ Do tej problematyki nawiązał Józef Gierowski (Między saskim absolutyzmem a złota wolnościa. Z dziejów wewnętrznych Rzeczypospolitej w latach 1712-1715, Wrocław 1953, s. 9-16). Kontekstem środowiska przyrodniczego w życiu człowieka interesowali się Zbigniew Kuchowicz (Człowiek polskiego baroku, Łódź 1992, s. 11-21, 200-207) i Stanisław Achremczyk (Człowiek doby baroku a środowisko, w: Życie codzienne na dawnych ziemiach pruskich. Człowiek a środowisko, red. H. Królikowska, Olsztyn 1999, s. 32-39). Zjawiska przyrodnicze znalazły się również w polu zainteresowań historyków podejmujących problem mentalności i kultury doby staropolskiej. Zob.: Bogdan Rok (Kalendarze polskie czasów saskich, Wrocław 1985, s. 99-101), Kazimierz Maliszewski (Obraz świata i Rzeczypospolitej w polskich gazetach rękopiśmiennych z okresu późnego baroku. Studium $z$ dziejów kształtowania się i rozpowszechniania sarmackich stereotypów wiedzy i informacji o Theatrum Mundi, Toruń 1990, s. 167-179; W kręu staropolskich wyobrażeń o świecie, Lublin 2006, s. 231-288). Tematykę zjawisk pogodowych na obszarach Rzeczypospolitej w dobie monarchii Wettinów podejmowali wspomniany już Franciszek Jukniewicz oraz Piotr Oliński (Warunki pogodowe w Toruniu i okolicach $w$ 1. połowie XVIII wieku w świetle źródeł narracyjnych, „Rocznik Toruński” 2002, t. 29, s. 49-85) i Dariusz Bąkowski-Kois (Zarządcy dóbr Elżbiety Sieniawskiej. Studium z historii mentalności 1704-1726, Kraków 2005, s. 123-127).

${ }^{5}$ Kanclerz wielki litewski Karol Stanisław Radziwiłł (1669-1719), wojewoda wileński i hetman wielki litewski Michał Kazimierz Radziwiłł „Rybeńko” (1702-1762), chorąży wielki litewski Hieronim Florian Radziwiłł (1715-1760), wojewoda wileński i hetman wielki litewski Michał Serwacy Wiśniowiecki (1680-1744), wojewoda trocki, Tadeusz Franciszek Ogiński (1712-1783), wojewoda miński Krzysztof Stanisław Zawisza (1666-1721).

${ }^{6}$ Administrator dóbr słuckich Stanisław Niezabitowski (1641-1717), stolnik brzeski Marcin Matuszewicz (1714-1773), podstoli podlaski i major JKM Felicjan Piaskowski, podstarości piński i starosta obrowski Franciszek Szyrma (ok. 1665 - przed 1757), podstarości brzeski Karol Wieszczycki, Jerzy Erdman.

${ }^{7}$ Biskup diocezareński i prepozyt trocki Józef Julian Sapieha (1708-1754), bazylianin o. Jan Oleszewski, dominikanin o. Wojciech Bagiński.

${ }^{8}$ Mieszczanin witebski Michał Pancerny, mieszczanin witebski Stefan Hawriłowicz Awierke (Awierko), burmistrz Witebska Gabriel Kuriłowicz Awierke (Awierko). 
Schlemüllera (1752). Jeśli chodzi o wykorzystane przeze mnie gazety drukowane: „Poczta Królewiecka” ukazywała się nakładem drukarni Jana Dawida Cenkiera (zm. 1727); „Kuryer Polski” był od 1729 r. wydawany przez oo. pijarów, a następnie (od 1737 r.) przez oo. jezuitów; podobnie jak „Kurier Litewski” (redaktorzy - jezuici: o. Franciszek Paprocki SJ (1723-1805), o. Aleksander Januszkiewicz SJ).

Terminologia meteorologiczna zastosowana $\mathrm{w}$ niniejszym artykule została przeze mnie wykorzystana w nawiązaniu do koncepcji znaczeń przyjętych w Słowniku meteorologicznym (Warszawa 2003). Pod określeniem „elementy meteorologiczne" rozumiem zbiór danych fizycznych charakteryzujących stan atmosfery ${ }^{9}$. Zjawiska atmosferyczne (meteory) to zjawiska występujące w atmosferze ziemskiej i na powierzchni planety, wyróżnia się kilka ich grup: elektrometeory (burze, błyskawice, pioruny, grzmoty, zorza polarna, ognie św. Elma), fotometeory (zjawiska optyczne w atmosferze: halo, wieniec, iryzacja chmur, gloria, tęcza i in.), hydrometeory (opady atmosferyczne: deszcz, mżawka, śnieg, grad i in., cząstki zawieszone lub unoszone, m.in.: mgła, zamieć śnieżna i in., osady atmosferyczne: rosa, szron, sadź/ szadź, gołoledź) oraz litometeory ${ }^{10}$. Materiał badawczy zawiera również relacje odnoszące się do klęsk żywiołowych ${ }^{11}$ czy też klęsk elementarnych. Oba wyrażenia są późniejsze. W omawianym czasie nie spotykamy w źródłach pisanych jednego precyzyjnego wyrażenia, które obejmowałoby swoim znaczeniem wszystkie katastrofy będące skutkiem czynników przyrodniczych. Wspominając je, używano określeń: „klęski”, „plagi”12, calamitates $^{13}$, magna clades $^{14}$ $\mathrm{i}$ in. Słowa te miały szerokie znaczenie. Odnoszono je do wszelkich zjawisk - nie

${ }^{9}$ Są to: temperatura powietrza, wilgotność powietrza, opady atmosferyczne, wiatr, zachmurzenie, usłonecznienie, widzialność. Słownik meteorologiczny, red. T. Niedźwiedź, Warszawa 2003, E73, s. 84.

${ }^{10}$ Ibidem, M95, s. 187, E61, s. 82-83, F100, s. 99, H60, s. 119, L45, s. 175.

${ }^{11}$ Wyrażenie „klęska żywiołowa” zastosowałem z uwagi na powszechne funkcjonowanie we współczesnym języku polskim oraz w literaturze. Trzeba jednak pamiętać, że w XVIII w. tragiczne w skutkach wydarzenia, stanowiące konsekwencję uwarunkowań przyrodniczych, odpowiadają znaczeniowo współczesnej definicji „katastrofy naturalnej” zgodnie z Ustawą z 18 kwietnia 2002 r. o stanie klęski żywiołowej (Dz.U. 2002, Nr 62, poz. 558, Art. 3).

${ }^{12}$ M.A. Troc, Nowy dykcyonarz to iest mownik polsko-niemiecko-francuski z przydatkiem przysłow potocznych, przestrog gramatycznych, lekarskich, matematycznych, fortyfikacyjnych, żeglaskich, łowczych i inszym naukom przyzwoitych wyrazow, tom trzeci, Leipzig 1779, s. 588, 1437; I. Włodek, Slownik polski dawny Czyli Zebranie słow dawnych zaniedbanych Polskich z ich tłömaczeniem, w: idem, O naukach wyzwolonych w powszechnosci, i szczegulnosci ksiegi dwie, Rzym 1780, s. 63 (po s. 415); M.S.B. Linde, Słownik języka polskiego, t. 2, cz. 2, Warszawa 1811, s. 723; Słownik staropolski, red. nacz. S. Urbańczyk, t. 6, Wrocław-Warszawa-Kraków-Gdańsk 1970-1973, s. 148; Słownik polszczyzny XVI wieku, red. nacz. M.R. Mayenowa, t. 7, Wrocław-Warszawa-KrakówGdańsk 1970-1973, s. 381, t. 24, Warszawa 1996, s. 317; Słownik języka Jana Chryzostoma Paska, red. nacz. H. Koneczna, t. 2, Wrocław-Warszawa-Kraków-Gdańsk 1973, s. 118.

${ }^{13}$ G. Rzączyński, Historia naturalis curiosa Regni Poloniae, Magni Ducatus Lituaniae, annexarumq; provinciarum, in tractatus XX, Sandomiriae 1721, s. 368.

${ }^{14}$ Wyrażenie użyte w nawiązaniu do mrozów podczas zimy $1709 \mathrm{r}$. Biblioteka im. Zielińskich Towarzystwa Naukowego Płockiego w Płocku [dalej: BTNP], rkps 113, k. 95. 
tylko naturalnych, ale też związanych z działalnością człowieka - które przybierały znamiona kataklizmów przez swą nietypową długotrwałość i intensywność. Zagrażały życiu ludzi i zwierząt oraz mieniu i plonom na określonym terytorium bądź obejmowały zasięgiem oddziaływania cały obszar państwa ${ }^{15}$. Nawiązując do wykładni biblijnej, traktowano je jako „bicz boży”, „karanie boskie”. Uciekano się przed nimi do wstawiennictwa Stwórcy, czego ślad odnajdujemy w popularnym hymnie suplikacyjnym Święty Boże, Święty Mocny... (Trishagion) ${ }^{16}$. Jego pierwsze znane publiczne odśpiewanie miało miejsce w $451 \mathrm{r}$. podczas soboru chalcedońskiego, a synod trullański (692 r.) zalecał jego śpiewanie w czasie wszelkich kataklizmów ${ }^{17}$. Hymn jest obecny w liturgii katolickiej, także w celebrowanych dzisiaj nabożeństwach (m.in. procesja w Uroczystość Najświętszego Ciała i Krwi Pańskiej odbywana we czwartek 60 dni po Wielkanocy).

Cel pracy stanowi omówienie zjawisk pogodowych i klęsk żywiołowych, które znalazły odzwierciedlenie w źródłach narracyjnych, oraz próba ukazania codziennej konfrontacji człowieka $\mathrm{z}$ siłami natury. Moim zamierzeniem nie jest formowanie wniosków $\mathrm{z}$ dziedziny klimatologii, tezy takie winny być owocem badań zespołu interdyscyplinarnego ${ }^{18}$.

${ }^{15}$ Dla o. Gabriela Rzączyńskiego „klęski” (calamitates) to przede wszystkim wielki głód i epidemie chorób zakaźnych (głównie dżuma), ale wymienia tu również kołtun (G. Rzączyński, Historia naturalis curiosa..., s. 368-380; idem, Auctuarium historiae naturalis curiosae Regni Poloniae Magni Ducatus Lithuaniae, annexarumque provinciarum, Gedani 1745, s. 466-471). Krzysztof Zawisza odnotowując katastrofy, które miały miejsce w latach 1690-1715, nazwał je „klęskami”, w spisie Notacya różnych klęsk i przygód pamięci godnych uwzględnił plagi owadów, epidemie chorób zakaźnych i ludzi, głód, a także zaćmienia słońca, grabieże wojskowe, i straty własnych zwierząt (Pamiętniki Krzysztofa Zawiszy, wojewody mińskiego. (1666-1721), wyd. J. Bartoszewicz, Warszawa 1862, s. 360-365). W lipcu 1741 r. Michał Kazimierz Radziwiłł w swoim diariuszu odnotował fakt odprawiania w kościele ołyckim modlitw błagających o Boże wybawienie: „od głodu, powietrza, wojny, ognia i gradów" (Archiwum Główne Akt Dawnych [dalej: AGAD], Archiwum Radziwiłłów [dalej: AR], dz. VI, sygn. II-80a, s. 1135). Sześć lat wcześniej, 22 lipca 1736 r. M.K. Radziwiłł zapisał, że w kościele kolegiackim pw. Męczeństwa św. Jana Chrzciciela w Warszawie było odprawione czterdziestogodzinne nabożeństwo, „błagając Majestat Boski ażeby wodami i powodziami nie karał, jakoż ludzie nie pamiętają takich powodzi” (ibidem, s. 780). Pod koniec czerwca $1751 \mathrm{r}$. w diecezji wileńskiej z powodu nieustannych deszczy odbywały się w kościołach publiczne suplikacje „na uproszenie oddalenia tey plagi” ( $Z$ Wilna d. 26. Junji, „Kuryer Polski” 1751, nr 772). W lipcu 1755 r. „plagami” nazwano pożary i pomór bydła (Z Wilna dnia 14 Lipca, „Kuryer Polski” 1755, nr 105). Rok później, w ostatniej dekadzie czerwca 1756 r. podczas wizytacji biskupa płockiego w dekanacie ciechanowskim modlono się o przebłaganie od deszczy, gradów, piorunów i nawałnic (Z Lekowa z Dekanatu Ciechanowskiego dnia 29. Czerwca, „Kuryer Polski” 1756, nr 155).

${ }^{16}$ B. Chmielowski, Nowe Ateny albo akademia wszelkiey scyencyi petna, na rozne tytuły iak na classes podzielona, mądrym dla memoryału, idiotom dla Nauki, politykom dla Práktyki, melancholikom dla rozrywki, cz. 3, Lwów 1755, s. 452.

${ }^{17}$ B. Nadolski, Leksykon liturgii, Poznań 2006, s. 1631.

${ }^{18}$ Klimatologia historyczna korzysta z doświadczeń różnych dziedzin naukowych, opierając się na źródłach: geologicznych, glacjologicznych, biologicznych i historycznych. Omówienie nauko- 
Weryfikację i analizę zjawisk pogodowych występujących na obszarze Wielkiego Księstwa Litewskiego w epoce nieusystematyzowanych pomiarów instrumentalnych utrudnia w pierwszym rzędzie brak regularnych zapisków. Nie są znane $\mathrm{z}$ terenu wczesnonowożytnej Litwy prace naukowe czy paranaukowe opisujące stan pogody i temperatury, jakie zostały sporządzone i ogłoszone drukiem dla obserwacji w Warszawie, Toruniu, Gdańsku czy znajdującym się wówczas poza granicami kraju Wrocławiu ${ }^{19}$. Jeśli chodzi o w miarę regularne notatki meteorologiczne z ziem litewskich, dysponujemy jedynie przekazami memuarystycznymi, które wyszły spod pióra Jana Antoniego Chrapowickiego (dotyczą II połowy XVII w. ${ }^{20}$ i Stanisława Niezabitowskiego (niektóre spostrzeżenia odnoszą się do

wych podstaw badań paleoklimatycznych zob. D. Limanówka, Rekonstrukcja warunków klimatycznych Krakowa w pierwszej połowie XVI wieku, Warszawa 2001, s. 9 (tabela 1.2.1.). W ostatnim czasie problematyka klimatu w okresie historycznym jest analizowana w drodze projektów interdyscyplinarnych (czego wcześniej nie praktykowano), wspólnie przez historyków oraz badaczy związanych z naukami o Ziemi (klimatolodzy, geofizycy, dendrochronolodzy). W latach 19992002 pod kierunkiem prof. Gabriela Wójcika (Katedra Meteorologii i Klimatologii Wydziału Nauk o Ziemi UMK w Toruniu) był realizowany projekt badawczy Rekonstrukcja klimatu na ziemiach polskich w okresie XVI-XIX w. na podstawie źródeł historycznych, dendroklimatologicznych, geofizycznych oraz instrumentalnych (Projekt badawczy KBN nr 6 P04E 022 16). Podczas działań w ramach projektu współpracowali ze sobą badacze z Instytutu Geografii UMK i Instytutu Historii i Archiwistyki UMK (R. Przybylak, G. Wójcik, K. Marciniak, W. Chorążyczewski, W. Nowosad, P. Oliński, K. Syta, Zmienność warunków termiczno-opadowych $w$ Polsce $w$ okresie 1501-1840 w świetle danych historycznych, „Przegląd Geograficzny” 2004, t. 76, z. 1, s. 5). Spośród opracowań stanowiących dorobek badaczy wywodzących się z kręgu nauk o Ziemi należy wymienić prace Jerzego Michalczewskiego (Średnia temperatura dobowa w Warszawie w latach 1760-1763, „Przegląd Geofizyczny” 1988, t. 33, z. 4, s. 473-478), Janusza Filipiaka (Obserwacje i pomiary opadów atmosferycznych w Gdańsku w XVIII wieku, w: Wahania klimatu w różnych skalach przestrzennych i czasowych, red. K. Piotrowicz, R. Twardosz, Kraków 2007, s. 365-373) oraz Rajmunda Przybylaka i Aleksandry Pospieszyńskiej (Charakterystyka hydrometeorów $w$ Toruniu $w$ okresie 1760-1764, w: Rozwój zrównoważony regionów Polski, red. W. Wysota, Toruń 2011, s. 157-165; Temperatura powietrza w Toruniu w okresie 1760-1764, w: Klimat Polski na tle klimatu Europy. Warunki termiczne i opadowe, red. E. Bednorz, Poznań 2010, s. 53-66; Air Temperature in Wrockaw (Breslau) in the period 1710-1721 based on Measurements made by David von Grebner, „Acta Agrophysica. Meteorology and Climatology Research” 2010 t. 5, nr 184, s. 35-43).

${ }^{19}$ Dzieje regularnych obserwacji pogodowych na ziemiach polskich przedstawił i omówił Rajmund Przybylak (Instrumental Observations, w: The Polish Climate in the European Context An Historical Overview, red. R. Przybylak, J. Majorowicz, R. Brázdil, M. Kejna, Berlin-Heidelberg-New York 2010, s. 129-160).

${ }^{20}$ J.A. Chrapowicki, Diariusz, cz. 1: Lata 1656-1664, oprac. T. Wasilewski, Warszawa 1978, cz. 2: Lata 1665-1669, oprac. A. Rachuba, T. Wasilewski, Warszawa 1988, cz. 3: Lata 1669-1673, oprac. L.A. Wierzbicki, Warszawa 2009. Omówienie zapisek pogodowych występujących w oryginalnym diariuszu J.A. Chrapowickiego oraz w późniejszych kopiach jego pamiętnika przedstawili Wiesław Nowosad, Rajmund Przybylak, Kazimierz Marciniak i Krzysztof Syta (Diariusz Jana Antoniego Chrapowickiego jako źródło do badań klimatu $w$ Rzeczypospolitej $w$ drugiej połowie XVII wieku, „Klio” 2007, nr 9, s. 23-36). 
stosunków pogodowych w latach 1697-1701)21. Wszystkie wzmianki źródłowe z Litwy stanowią owoc obserwacji nieregularnych i przypadkowych, a także potocznych, niewynikających $\mathrm{z}$ usystematyzowanych pomiarów naukowych. Większość relacji jest enigmatyczna, co pozwala jedynie na odnotowanie czasu i miejsca wystąpienia zjawisk. $Z$ drugiej strony charakterystyczna dla pewnej części opisów jest amplifikacja.

Powszechnie wiadomo, że znaczny wpływ na postrzeganie zjawisk atmosferycznych omawianej epoki wywarł prowidencjalizm. Barokowa konceptualizacja świata była oparta na wykładni biblijnej, a światopogląd chrześcijański wypełniał wszystkie dziedziny codzienności. Formuły odnoszące się do Boga, a mające charakter postulatywny, deklaratywny bądź wyrażający akceptację woli Stwórcy, stanowiły zwyczajową konwencję przyjętą w narracji wszystkich omawianych źródeł. Wśród ich autorów najwięcej było rzymskich katolików, ale znajdujemy tu także unitów oraz po jednym przedstawicielu konfesji ewangelicko-reformowanej oraz prawosławia. Specyfika epoki to uznawanie ingerencji Boga w życie ziemskie za przyrodzony aksjomat. Niemniej jednak oprócz hermeneutyki chrześcijańskiej wpływ na eksplikację zjawisk przyrodniczych miały także stereotypy tkwiące korzeniami w wierzeniach pogańskich (rudymentarne formy tradycyjnych systemów religijnych były żywe w kulturze ludowej jeszcze w XX w., a nawet funkcjonują obecnie). Równie przemożne znaczenie w odbiorze środowiska naturalnego przypadło $\mathrm{w}$ udziale popularnej astrologii.

Psycholog Piotr Próchniak stwierdził, że pogoda jawi się „ukrytym wymiarem zachowania osoby", stanowiąc jeden z najistotniejszych komponentów funkcjonowania emocjonalnego, poznawczego oraz behawioralnego jednostki ludzkiej ${ }^{22}$. Ale powszechnie wiadome jest oddziaływanie czynników meteorologicznych nie tylko na psychikę, ale również na sferę somatyczną człowieka ${ }^{23}$. Znamy reakcje organizmu na „normalne” bądź skrajne temperatury, stopień wilgotności, prędkość wiatru czy intensywność promieniowania słonecznego.

O truizm ociera się stwierdzenie, że człowiek I połowy XVIII w. był dużo bardziej uzależniony od warunków przyrodniczych niż społeczeństwo XXI stulecia. Egzystencja oparta na gospodarce rolniczej wymuszała większe zainteresowanie warunkami meteorologicznymi, a także szerzej - kontekstem przyrodniczym. Nie ulega wątpliwości, że szczególnie wrażliwi na sytuację meteorologiczną byli

${ }^{21}$ S. Niezabitowski, Dzienniki 1695-1700, oprac. A. Sajkowski, Poznań 1998.

22 P. Próchniak, Człowiek wobec zagrożeń pogodowych: konfrontacja i prewencja, Toruń 2014, s. 139.

${ }^{23}$ Zob.: J. Grączewski, Wpływ pogody na zdrowie człowieka (uwagi lekarza o biometeorologii), Warszawa 1972, s. 37-131; P. Trojan, Bioklimatologia ekologiczna, Warszawa 1985, s. 141-145; Biometeorologia człowieka, red. J. Jankowiak, Warszawa 1976; T. Kozłowska-Szczęsna, K. Błażejczyk, B. Krawczyk, Bioklimatologia człowieka. Metody i ich zastosowanie w badaniach bioklimatu Polski, Warszawa 1997; T. Kozłowska-Szczęsna, B. Krawczyk, M. Kuchcik, Wpływ środowiska atmosferycznego na zdrowie i samopoczucie człowieka, Warszawa 2004, s. 13-42. 
chłopi, czego ślad pozostał w bogatych wyobrażeniach ludowych ${ }^{24}$ oraz licznych przysłowiach $^{25}$.

Sytuacja pogodowa wpływała również na codzienne funkcjonowanie przedstawicieli mieszczaństwa, którego byt opierał się na gospodarce towarowo-pieniężnej, handlu, różnych gałęziach rzemiosła czy działalności usługowej. Zjawiska atmosferyczne warunkowały także powszedniość szlachty i magnaterii, podstawą ich pozycji było wszak użytkowanie ziemi. Co ciekawe, interesująca nas problematyka nie zajmuje jednak w ich zapiskach dużo miejsca ${ }^{26}$. Niewiele pisano o sytuacjach oczywistych, najbardziej frapujące były wszelkie odstępstwa od normy i kataklizmy. Warunki pogodowe odnotowywano też w momencie, gdy bezpośrednio ingerowały w codzienność w pozytywny bądź negatywny sposób. Przeanalizowane wzmianki dotyczą przede wszystkim spostrzeżeń zarejestrowanych w czasie podróży lub też stanowią doniesienia o warunkach umożliwiających bądź utrudniających przemieszczanie się czy też spędzanie czasu wolnego. Pewna część odnalezionych zapisków odnosi się również bezpośrednio do problematyki gospodarczej.

Na działanie warunków pogodowych człowiek był narażony podczas podróży. Zimową porą szczególnie ceniono przejezdną trasę, określając ją jako „sanna droga” ${ }^{27}$.

${ }^{24}$ Por.: K. Moszyński, Kultura ludowa Słowian, cz. 2: Kultura duchowa, Kraków 1934, s. 44-58; Słownik stereotypów i symboli ludowych, red. J. Bartmiński, t. 1: Kosmos, cz. 3: Meteorologia, Lublin 2012.

${ }^{25}$ Por. Nowa księga przysłów i wyrażeń przysłowiowych polskich, red. J. Krzyżanowski, t. 1, Warszawa 1969 , s. 421-422, t. 2, Warszawa 1970, s. 593-544, 931-935, 989, t. 3, Warszawa 1972, s. 463-464, $515,651-658$.

${ }^{26}$ Przykładowo w liczącym 2327 stron diariuszu Michała Kazimierza Radziwiłła (obejmującym lata 1703-1761) odnalazłem tylko 160 wzmianek (Korona i Litwa) dotyczących tematyki meteorologicznej, w diariuszu jego ojca Karola Stanisława Radziwiłła (1697-1713) - 22 wzmianki (Korona i Litwa), w pamiętniku Marcina Matuszewicza w latach 1714-1763 zostało odnotowanych 45 wzmianek (Korona i Litwa), w diariuszu Stanisława Niezabitowskiego (1697-1701) - 88 wzmianek (Litwa). Krzysztof Zawisza w swoim pamiętniku 12 razy wspomniał o warunkach pogodowych z terytorium Litwy, a Franciszek Szyrma podał 13 wzmianek odnoszących się głównie do powiatu pińskiego. Porównując, warto zauważyć, że mieszczanin toruński Dawid Brauer odnotował w swym pamiętniku obejmującym lata 1713-1750 aż 909 wzmianek pogodowych z Torunia okolic, a inny torunianin, Johannes Richtsteig w latach 1704-1730 zarejestrował 51 wzmianek (P. Oliński, op. cit., s. 58-59). Wójt Żywca, Andrzej Komoniecki z kolei w swojej kronice odnotował 172 wzmianki o zjawiskach meteorologicznych w latach 1697-1728 z Żywca i okolic (obliczenia własne, na podstawie: Chronografia albo Dziejopis żywiecki, wyd. S. Grodziski, I. Dwornicka, Żywiec 1987, s. 260-570). „Kuryer Polski” w latach 1730-1759 opublikował tylko 50 wzmianek dotyczących warunków meteorologicznych na terytorium litewskim. Należy zauważyć, że w latach 1760-1763 w „Kuryerze Polskim”, „Wiadomościach Uprzywileiowanych Warszawskich” (wydawanych od 1761 r.) i „Kuryerze Warszawskim” (1762-1763) nie pojawiło się żadne doniesienie o zjawiskach pogodowych na Litwie.

${ }^{27} Z$ Wilna d. 27. Januarii, „Kuryer Polski” 1737, nr 6; Z Brześcia d. 1. Febr., „Kuryer Polski” 1740, nr 161; Z Wilna d. 19. Febr., „Kuryer Polski” 1741, nr 221; M. Matuszewicz, Diariusz życia mego..., oprac. B. Królikowski, komentarz Z. Zielińska, t. 2, Warszawa 1986, s. 189 (1762). 
Krzysztof Zawisza, który 27 marca 1715 r. dotarł do Bakszt (powiat oszmiański), zaznaczył, że podróżował saniami „niezbyt złą drogą, bo były jeszcze śniegi i przymrozki” ${ }^{28}$. „Kuryer Polski” w 1730 r. odnotował, że w rejonie Witebska w ostatniej dekadzie grudnia „mrozy y śniegi sprawiły dobrą sanną drogę"29. Zadowolenie budziła ilość śniegu wystarczająca do podróżowania saniami, obawiano się zawianych dróg uniemożliwiających sprawny transport, co skutkować mogło niejednokrotnie również zabłądzeniem ${ }^{30}$. Opisujący podróż z Kaczanowicz do Wolnej, 3 stycznia 1700 r. Stanisław Niezabitowski zanotował: „złej nader zażywając drogi dla wielkiego nieprzetartego śniegu"31. Felicjan Piaskowski przypominał, że zmorą jego wyjazdu na Litwę z Wołynia w 1729 r. były „śniegi i niesłychanie złe drogi", ale mimo tych przeszkód udało mu się dojechać do Wisznic (powiat brzeski) wieczorem w sobotę zapustną ${ }^{32}$. Duże śniegi znacznie opóźniały przejazd kawalkady magnackiej prowadzącej ciężkie wozy ${ }^{33}$. Śnieżne zaspy utrudniały bądź uniemożliwiały polowania. Krzysztof Zawisza odnotował nieudaną obławę na niedźwiedzia w okolicy Białej (województwo nowogródzkie) 14 listopada 1698 r., o której fiasku zadecydowały: późna pora, „dzień mroźny i śnieg niemały”34. Dziesięć miesięcy wcześniej „śnieg głęboki” uratował mu podczas polowania życie. 27 stycznia 1698 r. pod Turcem (powiat oszmiański) odbyła się obława na dwa niedźwiedzie. Zawisza ranił jedno ze zwierząt, ale rozsierdzony niedźwiedź prawdopodobnie rozszarpałby swojego napastnika, gdyby myśliwy nie schronił się w głębokim śniegu. Dalszy pościg za zwierzęciem nie przyniósł rezultatu z powodu zapadającego zmierzchu i braku możliwości przedzierania się konnych myśliwych i psów niezamarzniętymi bagnami ${ }^{35}$.

Opad śniegu pokrzyżował prace komisji generalnej wohińskiej, w 1753 r. rozstrzygającej spór graniczny między ekonomią brzeską a dobrami podstolego drohickiego Mikołaja Kuczyńskiego. Wskutek niespodziewanej zmiany warunków pogodowych opóźnione zostało sypanie kopców granicznych ${ }^{36}$.

Szczególnie uprzykrzonym zjawiskiem podczas podróży bądź polowania były burza śnieżna, śnieg $\mathrm{z}$ wiatrem lub też wiatr rozwiewający zaspy śnieżne, zawiewający drogę, co ograniczało widoczność. W źródłach znalazły się różne

\footnotetext{
${ }^{28}$ Pamiętniki Krzysztofa Zawiszy..., s. 163.

${ }^{29}$ Z Witebska d. 29. Dec., „Kuryer Polski” 1730, nr 52, s. 215.

${ }^{30}$ Z Witebska d. 7. Febr., „Kuryer Polski” 1731, nr 62, s. 165.

${ }^{31}$ S. Niezabitowski, op. cit., s. 258.

${ }^{32}$ Pamiętnik Felicyana Junoszy-Piaskowskiego podstolego podlaskiego, majora J.K. Mości począwszy od roku 1690, Lwów 1865, s. 115.

${ }^{33}$ Biblioteka Państwowej Akademii Nauk - Państwowej Akademii Umiejętności w Krakowie [dalej: BPAN-PAUKr], sygn. 977, k. 108 (9 III 1701, Stołowicze, nad rzeką Szczarą, w powiecie nowogródzkim).

${ }^{34}$ Pamiętniki Krzysztofa Zawiszy..., s. 62.

${ }^{35}$ Ibidem, s. 55.

${ }^{36}$ M. Matuszewicz, op. cit., t. 1, s. 371.
} 
nazwy wspomnianej sytuacji: „miecielica śnieżna”37, „sumieć”38, „śnieg wielki z wiatrem”39, „śnieżnica” ${ }^{40}$, „śnieżyca”41, „zamieć”42, „zawierucha”43. Marcin Matuszewicz wspomniał w pamiętniku niefortunną wyprawę swojego brata Wacława pod koniec 1743 r. lub na początku 1744 r. do Mińska na sesję Trybunału. Najtrudniejszy okazał się odcinek z Koledycz do Różany, który Wacław zamierzał przebyć zamarzniętymi bagnami ciągnącymi się na kilkukilometrowym obszarze. Zboczywszy z drogi, grupa podróżnych wjechała w niezamarzniętą część błot. W kryzysowej sytuacji zbiegł przewodnik obawiający się zapewne wzięcia odpowiedzialności za niewłaściwe prowadzenie. Po wyjechaniu z oparzelisk podróżni spotkali się z kolejną przeciwnością, gdyż „zawierucha z nawalnym śniegiem nastąpiła”. Niesprzyjające czynniki doprowadziły do zupełnego zasypania drogi, a w konsekwencji błądzenia kawalkady przez dzień w ostępach leśnych wśród „wielkich śniegów”. Następnej nocy dał o sobie znać „mróz ekstraordynaryjny”, co rodziło uzasadniony lęk o życie swoje i koni. Podróżni grzali się przy ogniu, pijąc roztopiony śnieg. Błądząc kolejny dzień, grupa dobrnęła wieczorem do nieznanej wsi, po dziennym odpoczynku ruszyła $\mathrm{w}$ dalszą drogę ${ }^{44}$. Podobnie podczas burzy śnieżnej zabłądził Michał K. Radziwiłł, 23 marca 1748 r. polujący na Polesiu za Sienkowiczami. Myśliwych zaskoczyła „wielka zawierucha”, która uniemożliwiła odnalezienie trzech postrzelonych łosi i dzika. W czasie poszukiwań zwierzyny zginął jeden pies, a myśliwi „strasznie błądzili”, połamali sanie i z trudnością o godz. 3 dotarli do wsi Lubani. Tu zatrzymali się na nocleg, czekając na nowe sanie $\mathrm{z}$ Łachwy ${ }^{45}$.

Zainteresowanie i zdziwienie budził opad śniegu, nieadekwatny do pory roku, w której miał miejsce. 2 maja 1697 r. Stanisław Niezabitowski podróżujący z Jatry do Sielca odnotował: „W drodze śnieg duży padał”46. W piątek i sobotę 11 i 12 maja 1731 r. w Wilnie padał tak gęsty śnieg z deszczem, „że się prawie zimowa pokazała pora”, a „Zielone Świątki tu się w białe odmieniły”. W niedzielę 13 maja zaczęło się już ocieplać ${ }^{47}$. Pięć lat później, 14 maja 1736 r. w okolicy Nieświeża „Wielka słota napadła śnieżyca $z$ wiatrem”. Mróz był przyczyną zgonów

\footnotetext{
${ }^{37}$ S. Niezabitowski, op. cit., s. 141 (1 II 1697, Sielec-Jatra).

${ }^{38}$ Pamiętniki Krzysztofa Zawiszy..., s. 50 (1 III 1697); S. Niezabitowski, op. cit., s. 183 (9 II 1698, okolice Starojelnej).

${ }^{39}$ S. Niezabitowski, op. cit., s. 258 (2 I 1700, okolice Rejówki).

${ }^{40}$ Ibidem, s. 262 (5 II 1700, Sielec-Jatra).

${ }^{41}$ Ibidem, s. 215 (22 XI 1698, Jatra-Mikulicze-Horodziszcze).

${ }^{42}$ Ibidem, s. 141 (31 I 1697, okolice Lidy).

${ }^{43}$ Pamiętniki Krzysztofa Zawiszy..., s. 62 (10 XI 1698, Rohotna); AGAD, AR, dz. VI, sygn. II-80a, s. 1035 (3 II 1740, Nieśwież-Hruszew); M. Matuszewicz, op. cit., t. 1, s. 814 (1757).

${ }^{44}$ M. Matuszewicz, op. cit., t. 1, s. 217-218.

${ }^{45}$ AGAD, AR, dz. VI, sygn. II-80a, s. 1571-1572.

${ }^{46}$ S. Niezabitowski, op. cit., s. 150.

${ }^{47}$ Z Wilna d. 13. May, „Kuryer Polski” 1731, nr 74, s. 319.
} 
ludzi i śmierci zwierząt, odnaleziono m.in. martwego pastucha i chłopa, który zmarł na wozie pod Turcem, nieżywy był również jego koń. W miejskiej trzodzie nieświeskiej zdechło wówczas 30 owiec. Goszczący u M.K. Radziwiłła w Koreliczach wojewoda wileński i hetman wielki litewski Michał Serwacy Wiśniowiecki niesprzyjające warunki pogodowe odczuł na własnej skórze, jak napisał jego szwagier: „od podagry miał nagabanie” 48 . Rok później Radziwiłł odnotował w swoim diariuszu sytuację pogodową, jakiej był świadkiem w Świerżnie i okolicy Nieświeża w przeciągu czterech dni: 6-9 kwietnia 1737 r. 6 kwietnia „niesłychany śnieg spadł". Przeciągający się przez te dni mróz i burza śnieżna były przyczyną zamarznięć bocianów i czapli. Ptaki dawały się żywcem łapać. Autor relacji dwukrotnie podkreślił niezwykłość sytuacji meteorologicznej i jej konsekwencje dla zwierząt, akcentując mające miejsce ekstremum („dość rzecz osobliwsza”, „rzecz bardzo osobliwsza" ${ }^{49}$. Wydarzeniem budzącym konsternację, podobnie jak w czasach dzisiejszych, były opady śniegu w okresie jesiennym. 22 września 1757 r. w Nieświeżu „śnieg spadł po kostki wieczorem, a cały dzień był mróz, zima dość prędko na początku jesieni zawitała" ${ }^{0}$. Michała K. Radziwiłła dziwiły również „wielkie śniegi” podczas odwilży 16 stycznia 1751, kiedy jechał z Jałówki do Krynek (województwo mińskie) ${ }^{51}$.

W przebadanych źródłach odnajdujemy doniesienia o najcięższych zimach epoki. Mroźna była zima przełomu lat 1699 i 1700. Stanisław Niezabitowski wspomniał szczególnie mroźne dni 22-23 grudnia 1699 r., które choć wyjątkowo zimne, były jednak pogodne ${ }^{52}$. Bazylianin o. Jan Oleszewski pisał o tym okresie: „zamrozki wielkie y ciężkie słoty, y niepogody woysku barzo dokuczaią" ${ }^{53}$. Katastrofalna w skutkach okazała się zima przełomu lat 1708 i 1709. Przebywający pod koniec 1708 r. w Pińsku hetman polny litewski Michał Serwacy Wiśniowiecki napisał zdawkowo: „Mrozy haniebnie wielkie” ${ }^{4}$. Szlachcic piński Franciszek Szyrma odnotował, że najcięższymi miesiącami tej zimy były styczeń i marzec. Niespotykane mrozy doprowadziły do licznych zgonów ludzi, wyniszczały zwierzęta i rośliny ${ }^{55}$. Karol Stanisław Radziwiłł wspomniał krytyczną odwilż 12-16 lutego 1709 r. w rejonie Białej (powiat brzeski), kiedy „wody wielkie poznosiły groble i mosty, tak w Cycyborku [Cicibor lub Ciciborek, dziś Cicibór Duży

\footnotetext{
${ }^{48}$ AGAD, AR, dz. VI, sygn. II-80a, s. 758-759.

${ }^{49}$ Ibidem, s. 825-826.

${ }^{50}$ Ibidem, s. 2010.

${ }^{51}$ Ibidem, s. 1771-1772 (16 I 1751, okolice Krynek).

${ }^{52}$ S. Niezabitowski, op. cit., s. 256 (22 XII 1699, Słuck).

${ }^{53}$ Abrys domowey nieszczęsliwosci y Wnętrznej Niesnaski, Woyny, Korony Polskiey y Wielkiego Xięstwa Litewskiego Pro Informatione Potomnym nastepujacym czasom Przez iedna Zakonna Osobe swiatu pokazany y z Załoscia wyrażony Anno 1721, wyd. F.K. Kluczycki, Kraków 1899, s. 10.

${ }^{54}$ M.S. Wiśniowiecki, Dla pamięci co się którego roku działo, w: Podole, Wołyń, Ukraina. Obrazy miejsc i czasów przez Aleksandra Przezdzieckiego, t. 1, Wilno 1841, s. 104.

${ }^{55}$ BTNP, rkps 113, k. 95.
} 
nad rzeką Klukówką - M.T.W.] jako i w Rozkoszy”. Zgodnie z relacją mrozy powróciły 18 lutego ${ }^{56}$.

Jako echo wspomnień rodzinnych doświadczenia zimy 1709 r. znalazły miejsce w notatce Michała K. Radziwiłła, który nawiązał do przebywania w Tylży jako siedmiolatek u boku swojej matki Anny z Sanguszków Radziwiłłowej w „samą najtęższą zimę". Tego samego roku przybyli do Białej ${ }^{57}$. Ciężka była zima 1740 r., przywodzący ją na myśl Marcin Matuszewicz napisał: „barzo mroźna i długa”. Pamiętnikarz wspominał znaczną ilość śniegu, odnotował przypadki zamarznięć ludzi i zwierząt. Twierdził, że od siarczystego mrozu pękała ziemia ${ }^{58}$. Ekstremalne temperatury, a następnie odwilż spowodowały, że zniszczeniu uległy akta grodzkie brzeskie ${ }^{59}$. Biskup diocezareński i prepozyt trocki Józef Julian Sapieha, który 6 stycznia 1740 r. przyjechał do Wilna, napisał, że dotarł tu „podczas tak tęgich mrozów, że ledwo podobne a memoria hominum pamiętają, z których okazij ledwo nie wszystkie drzewa fruktowe w połowie a osobliwie w Litwie wymarzły, tak zaś tęgie były, że trudno było przy ogniu co zagrzać, który zdał się był tracić niejako vim calefactivam. Wielką moc ludzi w całej Europie z tej okazij pomarzło"60. Niska temperatura utrzymywała się bardzo długo. W niektórych rejonach Litwy chłód uprzykrzał się jeszcze wiosną. W konsekwencji nieurodzaju pojawiło się niebezpieczeństwo głodu wśród ludzi, a także pomoru bydła. „Kuryer Polski” relacjonował sytuację w rejonie Witebska w połowie kwietnia 1740 r.: „Zima długo wytrzymuie, także dla niedostarczaiącego karmu bydło znacznie upadać musi, co u ludzi ubogich wielka konsternacya et summa afflictio" ${ }^{61}$. Odbywający podróż do Cetry na Żmudzi 11 maja 1740 r. Michał K. Radziwiłł napisał: „nieszczęście wielkie, że dotąd ciepła nie było" ${ }^{2}$. Na Wileńszczyźnie chłód i przymrozki dawały się we znaki w październiku 1740 r., „Kuryer Polski” donosił, że „[...] rożni przeiedzaiący czynią relacye, że śniegi po niektorych mieyscach w koláno zapadły" ${ }^{63}$.

Obfitująca w ekstremalnie niskie temperatury była zima przełomu lat 1762 i 1763, ale doniesienia o uprzykrzających się przymrozkach odnajdujemy już z lata, z lipca $1762 \mathrm{r}$. W dniach 15 i 17 lipca tego roku w Tułowie w województwie witebskim mróz spustoszył warzywa ogrodowe, groch i grykę $e^{64}$. W Nowogródku i okolicy między 4 a 8 października 1762 r. panowały letnie upały. Jednak w drugim tygodniu października pogoda uległa diametralnej zmianie. Pojawił się

\footnotetext{
${ }^{56}$ BPAN-PAUKr, sygn. 977, k. 211.

${ }^{57}$ AGAD, AR, dz. VI, sygn. II-80a, s. 3.

${ }^{58}$ M. Matuszewicz, op. cit., t. 1, s. 153.

${ }^{59}$ Ibidem, s. 157.

${ }^{60}$ Biblioteka Narodowa [dalej: BN], Biblioteka Ordynacji Zamojskiej [dalej: BOZ], sygn. 941, s. 311.

${ }^{61}$ Z Witepska [!] d. 14. April, ,Kuryer Polski” 1740, nr 173.

${ }^{62}$ AGAD, AR, dz. VI, sygn. II-80a, s. 1054.

${ }^{63}$ Z Wilna d. 9. Octobr, „Kuryer Polski” 1740, nr 202.

${ }^{64} Z$ Wilna dnia 30. Lipca, „Kurier Litewski” 1762, nr 31, k. 1.
} 
wiatr północny, a razem z nim deszcze, śnieg i mróz, który „barzo umartwił”65. Najzimniejszym dniem zimy odnotowanym w Wilnie był 27 grudnia $1762 \mathrm{r}$. Jak donosił „Kurier Litewski”, temperatura powietrza wyniosła wówczas 20,5 stopni na „termometrze paryskim”. Użyta nomenklatura wskazuje, że do pomiaru wykorzystywano zapewne skalę Réaumura, wobec czego temperatura powietrza według współcześnie stosowanej skali osiągnęła wartość $-25,6^{\circ} \mathrm{C}$. Podobną temperaturę (stopień wyższą) odnotowano w Wilnie 11 marca 1763 r., redaktor „Kuriera Litewskiego" napisał: „tęgie zaczeły tu panować i z wiatrem północnym mrozy”66. Matuszewicz wspominał pobyt w Nowogródku w pałacu Radziwiłłów, który ciężko było ogrzać z powodu przestronnych pomieszczeń, a drwa na opał kosztowały aż 800 tynfów $^{67}$ : „wieleśmy zimna nacierpieli się"68. Zimno uprzykrzało się nawet wiosną 1763 r., w trzeciej dekadzie maja napisano: „Powietrze u Nas dla swego zimna i wiatrów północnych zda się raczey ku ieśieni, niż ku latu zbliżać"69.

Spadek temperatury poważnie zakłócał wegetację roślin ${ }^{70}$. W źródłach prasowych, jak również pamiętnikarskich, odnotowywano niekiedy daty utrzymujących się przymrozków („zamrozków”) lub też rejestrowano fakty bardzo niskich temperatur w dni pory roku charakteryzującej się zazwyczaj ciepłem lub umiarkowanym chłodem $^{71}$. Dla Wileńszczyzny pamiętne były przymrozki ciągnące się od maja do czerwca 1742 r. Utrzymujące się niskie temperatury uniemożliwiły rozwój roślin, co było konsekwencją wzrostu cen. Mrozy powstrzymały także siew roślin jarych. Ciepła pogoda została odnotowana dopiero w drugim tygodniu czerwca, ale drożyzna utrzymała się $e^{72}$.

Bezpośrednimi konsekwencjami niskich temperatur dla zdrowia ludzkiego, o których pisano, były infekcje gardła, przeziębienia, kaszel, katar, odmrożenia, ogólnie złe samopoczucie. Źle znosił Michał K. Radziwiłł „mrozy wielkie” panujące w Kamieńcu (województwo brzeskolitewskie) w dniach 8-10 stycznia $1751 \mathrm{r}$. Według jego relacji z każdym dniem zimno stawało się coraz bardziej dojmujące. Nie mogąc znieść dyskomfortu, przeniósł się razem z żoną z pałacu do oficyny

${ }^{65}$ Z Nowogródka 10. Pazdźiernika, „Kurier Litewski” 1762, nr 43.

${ }^{66}$ Z Wilna 12. Marca, „Kurier Litewski” 1763, nr 11, Supplement do gazet wileńskich.

${ }^{67}$ W 1763 r. 1 tynf stanowił 38 gr (W. Adamczyk, Ceny w Lublinie od XVI do końca XVIII wieku, Lwów 1935, s. 25); 1 kopę (60 sztuk) jaj można było kupić wówczas w Lublinie za 60 gr (ibidem, s. 77); 1 garniec piwa (3,77 litra) kosztował tam 33 gr 69 szóstaków (ibidem, s. 80), a cena pary butów wynosiła od 76 do 138 gr (ibidem, s. 87).

${ }^{68}$ M. Matuszewicz, op. cit., t. 1, s. 290.

${ }^{69}$ Z Wilna D. 28. Maja, „Kurier Litewski” 1763, nr 22, Supplement do gazet wileńskich.

${ }^{70}$ BTNP, sygn. 113, k. 104v (22 V 1718, Zarzecze); Z Kámieńca d. 3. Sept., „Kuryer Polski” 1741, nr 249.

${ }^{71}$ S. Niezabitowski, op. cit., s. 150 (4 V 1697, okolice Sielca), s. 275 (17 V 1700, Wilno); Z Witebská d. 4. Oct., „Kuryer Polski” 1731, nr 97, s. 415.

${ }^{72}$ Z Wilna d. 5. Maii, „Kuryer Polski” 1742, nr 284; Z Wilna d. 19. Maii, „Kuryer Polski” 1742, nr 287; Z Wilna d. 9. Junii, „Kuryer Polski” 1742, nr 289. 
gubernatorskiej, gdyż „drewniany pałac nie jest jeszcze na takie mrozy opatrzony"73. 12 marca 1739 r. mróz, jaki pojawił się gwałtownie po odwilży, był przyczyną infekcji gardła Michała K. Radziwiłła, której nabawił się w okolicy Siniowa 4 mile od Nieświeża ${ }^{74}$. Marcin Matuszewicz wspominał, że z powodu mrozów w drugiej połowie września $1753 \mathrm{r}$. w Rasnej dostał gorączki, nie mógł mówić z powodu

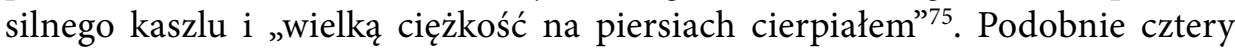
lata później, w połowie ostatniej dekady grudnia 1757 r. „wielkie mrozy” były przyczyną powszechnych przeziębień, „gorączki katarowej” trwającej trzy dni ${ }^{76}$.

Niska temperatura stała się też przyczyną śmierci starosty stokliskiego Jerzego Józefa Matuszewicza, ojca pamiętnikarza Marcina. 2 lutego 1754 r. podczas wielkiego mrozu Jerzy Matuszewicz odmroził sobie duży palec u lewej stopy podczas nabożeństwa w kościele oo. Marianów w Rasnej. Zaniedbane odmrożenie stało się przyczyną gangreny prowadzącej do śmierci (zmarł 12 III 1754) ${ }^{77}$. Michał K. Radziwiłł odczuwał dolegliwości złamanej ręki podczas „tęgiego zimna” w Nieświeżu w dniach 11-16 listopada $1758 \mathrm{r}^{78}$ Nie chcąc wystawiać się na chłód, uczestniczył we mszy św. w zakrystii kościoła oo. Jezuitów, podobnie rok później, 20 grudnia 1759 r. podczas wizyty w Nieświeżu księcia Kurlandii i Semigalii, królewicza Karola Chrystiana, aby uniknąć mrozów, słuchano mszy św. w zakrystii jezuickiej ${ }^{79}$. Tydzień później (27 XII) również z powodu mrozu Radziwiłł uczestniczył w nabożeństwie $\mathrm{w}$ nieświeskim kościele zamkowym ${ }^{80}$.

W miarę możliwości starano się unikać ekstremalnie niskich temperatur. 29 września 1698 r. przebywający w Usnaszu na Grodzieńszczyźnie Krzysztof Zawisza odesłał swoje dzieci do Rohotnej (powiat słonimski) z powodu mrozów i braku zapewnienia materiału opałowego ${ }^{81}$. Zimno i niepogoda 16 czerwca $1739 \mathrm{r}$. były przyczyną pozostania w pałacu w Koreliczach Michała K. Radziwiłła ${ }^{82}$. Jego brat Hieronim Florian, chcący uczcić wigilię Bożego Narodzenia w 1750 r. polowaniem pod Delatyczami (powiat nowogródzki), przyznał się do sromotnej rejterady z pola, czego przyczyną był siarczysty mróz: „Obchodząc Wilię Bożego Narodzenia trybem u myśliwych zwykłym, jeździłem w pole, lecz nam wszystkim gdy się na zamarźnienie [!] od tęgiego mrozu zaniosło, sam do sprofanowania reguł myśliwskich uciekaniem z pola byłem powodem zajęczynę jedną chartami zamęczywszy" ${ }^{\text {"83 }}$.

\footnotetext{
${ }^{73}$ AGAD, AR, dz. VI, sygn. II-80a, s. 1771.

${ }^{74}$ Ibidem, s. 976.

${ }^{75}$ M. Matuszewicz, op. cit., t. 1, s. 367.

${ }^{76}$ Ibidem, s. 855 .

77 Ibidem, s. 375.

${ }^{78}$ AGAD, AR, dz. VI, sygn. II-80a, s. 2198.

${ }^{79}$ Ibidem, s. 2251.

${ }^{80}$ Ibidem, s. 2252.

${ }^{81}$ Pamiętniki Krzysztofa Zawiszy..., s. 61.

${ }^{82}$ AGAD, AR, dz. VI, sygn. II-80a, s. 993.

${ }^{83}$ Ibidem, sygn. II-81, k. 232v.
} 
W omawianych źródłach odnajdujemy wiele przykładów dotyczących procesów hydrologicznych zachodzących pod wpływem niskiej temperatury. Zjawiska lodowe na rzekach i zamarzanie bagien ułatwiały podróż bądź też znacznie ją utrudniały. Zamarznięte rzeki przyczyniały się do szybszego pokonywania odległości i oszczędności czasu ${ }^{84}$. O możliwości bezpiecznego przejazdu przez skute lodem wody informowały gazety ${ }^{85}$. Podobnie, jeśli chodzi o zamarznięte bagna. 18 grudnia 1741 r. Michał K. Radziwiłł odnotował zamarznięcie Hryczyńskiego Błota, ogromnej połaci bagien na Polesiu rozciągającej się na pograniczu powiatów pińskiego, mozyrskiego i Księstwa Słuckiego: „takie mrozy, że harmaty po Hryczynie prowadzić można" ${ }^{\prime 6}$.

Duże mrozy umożliwiały niekiedy przemieszczanie się po zamarzniętych miejscach nawet wiosną. Michał K. Radziwiłł donosił 11 maja 1740 r., że przebył zamarznięte błota pod nieznanym bliżej Zaduniem na Żmudzi, jedną milę od Cetry ${ }^{87}$. Wiele doniesień o przemieszczaniu się po zamarzniętych rzekach, jeziorach czy bagnach pochodzi z czasu działań wojennych, m.in. po podwójnej elekcji Stanisława Leszczyńskiego i Augusta III w latach 1734-1735, kiedy warunki ułatwiały operującym oddziałom pokonywanie w stosunkowo krótkim czasie niemożliwych do przebycia latem czy wiosną zabagnionych obszarów, rzek czy zbiorników wodnych ${ }^{88}$. Niejednokrotnie przeprawa przez zamarzniętą wodę wiązała się z dużym ryzykiem, np. podczas odwilży, jednak mimo niebezpieczeństwa i dostrzegalnej niewystarczającej grubości lodu decydowano się na przejazd, żeby uniknąć drogi okrężnej ${ }^{89}$. Czasem czekano na „podmarznięcie” rzeki, aby móc kontynuować podróż. Pod koniec pierwszego tygodnia marca 1737 r. Michał K. Radziwiłł podróżował po Pińszczyźnie. Uprzykrzał się bardzo słaby stan dróg. 6 marca kawalkada „niebezpiecznie” przebyła rzekę Jasiołdę, następnie przejechała 4 mile, by zatrzymać się w Porochońsku, gdzie czekano, żeby rzeka Bobryk podmarzła („czy nie podmarznie”). Następnego dnia karawanie udało się przejechać

${ }^{84}$ S. Niezabitowski, op. cit., s. 140 (19 I 1697, Sucha-Lida), s. 141 (31 I 1697, okolice Sielca); Путешествіе стольника П.А. Толстаго 1697-1699, „Русскій Архивъ” 1888, nr 8, s. 399 (29 I 1699, okolice Orszy); AGAD, AR, dz. VI, sygn. II-80a, s. 1050 (15 IV 1740, Płotnica-Chotynicze), s. 1455 (18 III 1747, podróż po powiecie pińskim, dojeżdża do Łachwy), s. 1456 (19 III 1747, Hryczyńskie Błoto), s. 1821 (5 XII 1751, Hryczyńskie Błoto).

${ }^{85}$ Z Witebska d. 29. Dec., „Kuryer Polski” 1730, nr 52, s. 215.

${ }^{86}$ AGAD, AR, dz. VI, sygn. II-80a, s. 1157.

${ }^{87}$ Ibidem, s. 1054.

${ }^{88}$ K. Bartoszewicz, Tadeusz Ogiński wojewoda trocki i jego pamiętnik (odbitka z „Przegladu Historycznego"), Warszawa 1913, s. 26; AGAD, AR dz. VI, sygn. II-80a, s. 680: 6 I 1735 (przejście Niemna pod Wasilewiczami), s. 681-682 (13 I 1735, przejście Niemna pod Dokudowem), s. 689 (13 II 1735, Niemen).

${ }^{89}$ BPAN-PAUKr, sygn. 977, k. 163 (4 IV 1705, Niemen pod Mikołajowem); AGAD, AR, dz. VI, sygn. II-80a, s. 974 (27 II 1739, okolice Łachwy, powiat piński), s. 1357 (17 III 1745, Dniestr pod Kopysią; 19 III 1745, Berezynie; 22 III 1745, Piaseczna nad Niemnem), s. 1411 (15 II 1746, Wola nad Szczarą); sygn. II-81, k. 227v (5 XII 1750, Bielica nad Niemnem). 
przez Bobryk „barzo słaby”90. Niekiedy też wyrąbywano lód na rzece, umożliwiając przeprawę promem, jak odnotował Michał K. Radziwiłł pod datą 18 marca 1743 r., kiedy koło Wieliczkowicz w powiecie brzeskim „przecięli” lód na Bugu, żeby ułatwić przepłynięcie ${ }^{91}$. W tym samym diariuszu odnajdujemy także inne sposoby pokonywania „niepewnych” lodów rzecznych. Niekiedy przejeżdżano rzekę w poprzek nawet kilka razy bądź przemieszczano się po lodzie brzegowym wzdłuż koryta. 20 marca 1748 r., jak pisał Radziwiłł: „Ujechawszy mil trzy po lodach kilka razy w poprzek miejscami w dłuż [!] Horynia, popasujem w Uhłach stamtąd mil cztery ujechawszy po lodach i przez Prypeć stanęliśmy szczęśliwie w Łachwie" 92 . Cztery lata później, 10 marca 1752 r. opisał niebezpieczny przejazd lodem brzegowym rzeki Wietlicy (prawy dopływ Prypeci, przy granicy powiatów pińskiego i mozyrskiego). Po noclegu w Orłach Wielkich wysłał przodem „Z wielkim niebezpieczeństwem po słabym ledzie [!]” wozy i karety „wzdłuż czwierć [!] mili rzeki”, sam zaś razem z żoną i dziećmi ruszył następnego dnia, „w tym azardzie życia niech nas Bóg na saneczkach prowadzi szczęśliwie" 93.

Podróżowanie zamarzniętą wodą mogło zakończyć się tragicznie. Michał K. Radziwiłł w swoim diariuszu opisał sześć przypadków - których był naocznym świadkiem - załamania się lodu pod przejeżdżającą kawalkadą bądź jedną osobą. Dwa razy w życiu (10 II 1735 i 20 XII 1741 r.), jak pisał, sam cudem uniknął utonięcia ${ }^{94}$. Za drugim razem stracił w rzece różne osobiste rzeczy, w tym dokumenty, z wielką ulgą wspominał ocalenie pamiętnika. $Z$ niefortunnego zdarzenia wyszły cało również bliżej nieokreślone osoby ze świty radziwiłłowskiej.

Podczas przejeżdżania przez Niemen pod Mikołajewem 31 marca $1731 \mathrm{r}$. szczęśliwie uchronił się przed śmiercią cudzoziemiec ze świty Radziwiłła, nieznany z imienia Mariati ${ }^{95}$. Ponad 10 lat później, 17 lutego 1743 r. Michał K. Radziwiłł odprowadzał po obiedzie w Nieświeżu do Stołpców goszczącego w dobrach radziwiłłowskich podskarbiego wielkiego litewskiego Jana Michała Sołłohuba. Gdy razem z towarzyszącym orszakiem pieszo przechodzili przez Niemen, załamał się lód pod Sołłohubem, który wpadł w wodę „po pas”, Radziwiłł osobiście udzielił mu pomocy: „ledwom najbliżej będąc wyciągną" ${ }^{\prime}$. Kawalkada radziwiłłowska miała ciężki przejazd po „barzo niebezpiecznym ledzie [!]” 30 grudnia 1744 r. 4 mile przed Orłami na Polesiu. W niebezpieczeństwie znaleźli się oficerowie regimentu dragońskiego M.K. Radziwiłła: por. Łojko i chor. Radowicki. Obaj uniknęli śmierci,

\footnotetext{
${ }^{90}$ AGAD, AR, dz. VI, sygn. II-80a, s. 822.

${ }^{91}$ Ibidem, s. 1235.

92 Ibidem, s. 1571.

${ }^{93}$ Ibidem, s. 1836.

${ }^{94}$ Ibidem, s. 687-688 (10 II 1735, przejazd przez Solczę, pow. lidzki), s. 1157 (20 XII 1741, pod Dawidgródkiem).

${ }^{95}$ Ibidem, s. 423.

${ }^{96}$ Ibidem, s. 1229.
} 
ale utonęły ich konie. Autor relacji wspomniał, że poszkodowanych było więcej: „inszych siła ludzi i koni co się tylko zkompali [!] i byli w wielkim niebespieczeństwie [!]"97. Szczęśliwy finał miał również dramatyczny przejazd przez zamarzniętą Wietlicę 16 grudnia $1752 \mathrm{r}$. Kareta płk. Woynarowskiego załamała się na lodzie, a jadący w niej kpt. Vieval cudem ocalił życie, choć najadł się strachu; wyskoczył w krytycznej sytuacji z zapadającego się w wodzie i kawałach lodu pojazdu i został wyciągnięty. Utonął jeden z koni dyszlowych. Po wypadku Radziwiłł zaniechał dalszej przeprawy, „nie chcąc azardować przejazdu”"

Podróż utrudniała lub całkiem udaremniała dryfująca po rzekach kra w okresach odwilży bądź wiosennych roztopów ${ }^{99}$. Na początku roku, 1 stycznia 1756 r. wielka kra na Niewiaży i Wilii uniemożliwiała przeprawę zdążającemu na własny ślub do Kowna Marcinowi Matuszewiczowi ${ }^{100}$. Uciążliwe dla podróżujących okazało się zjawisko lodu brzegowego odnotowane na Kowieńszczyźnie podczas mroźnej zimy w 1761 r. Marcin Matuszewicz wspominał: „Barzo wtenczas grube lody były, bo zima była tęga. Leżały tedy po brzegach Niemna, Wilii i Niewiaży kilkosążniowe szerokie, a na dwa łokcie ${ }^{101}$ grube bryły lodu, alias kry, gdyż nagle ciepła uderzyły $i$ te rzeki portowe połomały" 102 . Omijanie wypiętrzonych lodowych brył znacznie opóźniło drogę przejeżdżającemu przez Kowieńszczyznę pamiętnikarzowi.

Z kontekstu relacji niejednokrotnie można wydobyć nastrój niezadowolenia wynikający z niewygody podróżowania twardą, zrytą koleinami drogą, która nie została jeszcze przykryta śniegiem, będącą efektem pierwszych późnojesiennych czy już zimowych mrozów, rezultatem nadejścia niskich temperatur tuż po odwilży bądź też konsekwencją gołoledzi. Zmarznięta wyboista nawierzchnia stanowiła częstą przyczynę awarii pojazdów kołowych, a także różnych wypadków skutkujących utratą zdrowia czy rozmaitymi kontuzjami zarówno zwierząt, jak i ludzi. Nazywano ją „grudą"103, „ostrą drogą ${ }^{104}$, „ostrą grudą"105, „zimną drogą"106, „Zimnikiem”107.

97 Ibidem, s. 1343.

${ }^{98}$ Ibidem, s. 1886.

${ }^{99}$ M. Matuszewicz, op. cit., t. 1, s. 41 (XII 1731), s. 98 (1735, Wilia pod Żodziszkami); AGAD, AR, dz. VI, sygn. II-80a, s. 1688 (30 XI 1749, Kohorski Las); sygn. II-81, k. 220v (6 XI 1750).

${ }^{100}$ M. Matuszewicz, op. cit., t. 1, s. 604.

${ }^{101}$ Łokieć krakowski do $1764 \mathrm{r}$. - 58,6 cm; łokieć warszawski w II połowie XVII w. $-59,5 \mathrm{~cm}$, a od konstytucji 1764 r., kiedy stał się powszechnie stosowaną miarą $-59,55 \mathrm{~cm}$; łokieć litewski był większy od warszawskiego, wynosił $65,5 \mathrm{~cm}$; sążeń miał 3 łokcie małe bądź 2 łokcie duże. E. Stamm, Miary długości w dawnej Polsce, Warszawa 1935, s. 17, 20, 23.

102 M. Matuszewicz, op. cit., t. 2, s. 144.

103 S. Niezabitowski, op. cit., s. 172 (9 XI 1697, Jatra-Snowa), s. 229 (31 III 1699, Nieśwież-Hołynka), s. 254 (27 XI 1699, Słuck-Rejówka).

104 Ibidem, s. 172 (10 XI 1697), s. 215 (24 XI 1698), s. 222 (4 II 1699, Bielewicze-Sawicze).

${ }^{105}$ Ibidem, s. 254 (30 XI 1699, Mir-Jatra).

${ }^{106}$ Ibidem, s. 259 (12 I 1700, Sielec-Lida), s. 262 (4 II 1700, Berezna-Pieski).

107 Ibidem, s. 263 (13 II 1700, okolice Słucka). 
20 października 1762 r., po zakończonych w Birżach misjach prowadzonych przez oo. misjonarzy (zaczęły się 12 września), znany kaznodzieja, dominikanin o. Wawrzyniec Owłoczymski, goszczony przez strażnika wiłkomierskiego i starostę birżańskiego Franciszka Antoniego Komorowskiego, nie chciał dłużej zostawać w Birżach, gdyż „droga przed zimowa groziła się grudą i łomaniną”, a czekała go jeszcze daleka podróż. Następnego dnia, 21 października po śniadaniu odjechał w kierunku Wilna ${ }^{108} .22$ listopada 1726 r. Michał K. Radziwiłł po kolacji u swojej matki Anny z Sanguszków Radziwiłłowej zamierzał szybko dojechać do Korelicz, lecz pomysłowi nie sprzyjała pogoda, gdyż „śnieg spadł wielki”. Jechał całą noc saniami zaprzężonymi w trzy konie: „z dziesięć razy wywróciliśmy się, konie nam dla złej drogi ustali pod samym Mirem, [sanie] rozlecieli się dosyć, że do Mira kawałki sanek w rękę wziąwszy piechotą przyszli prosto do kościoła" ${ }^{109}$. Marcin Matuszewicz wspominał niefortunne i bolesne zdarzenie, jakie miało miejsce w 1736 r. Pamiętnikarz jechał z Kowna do Stokliszek, za Rumszyszkami miał niebezpieczny wypadek - koń poniósł na nierównościach drogi, „na wybojach jeszcze niedobrze śniegiem przykrytych”. Matuszewicz pisał, że z powodu upadku stracił przytomność: „Śniegu jeszcze było mało, takem się tedy na lewy bok padłszy mocno stłukłem, żem zaraz bez mowy został i bez pamięci leżał [...]"110. Ponad 20 lat później dramatycznemu wypadkowi uległa również jego żona Anna ze Szczytów $1^{\circ}$ v. Chechłowska $2^{\circ}$ v. Matuszewiczowa, będąca wówczas w ciąży. 27 marca 1758 r., drugiego dnia świąt wielkanocnych, wyjechała z dworu w Rasnej do kościoła, „a po rezolucji gruda naówczas była”. Podczas jazdy po zamarzniętej drodze jeden z koni „zaczął swywolić”. Gwałtowna, przykra i uciążliwa jazda po twardych wybojach stała się bezpośrednią przyczyną rozpoczęcia przedterminowej akcji porodowej i narodzin wcześniaka Adama Eustachego ${ }^{111}$.

Warunki w atmosferze ziemskiej sprzyjają niekiedy powstawaniu na niebie widowiskowych zjawisk optycznych, takich jak zjawisko halo, do których należą: pierścienie, łuki, słupy oraz plamy świetlne, słońca poboczne. Stanowią one rezultat odbicia promieni słonecznych od kryształków lodu w troposferze, zjawiskom towarzyszy także refrakcja, czyli załamanie światła we wnętrzu kryształków bądź inferencja (sposób odbicia). Wygląd zjawisk zależy od kształtu kryształów ${ }^{112}$.

108 „Kurier Litewski” 1762, nr 43, Przydatek Do Gazet Wileńskich. Krótkie Donieśienie o Missyi w Mieśćie Birżach Dobrach J.O. Xiążęćia Jmśći Karola Radziwiłła Wojewody Wileńskiego w Powiećie Upitckim za staraniem i nakładem tegoż J.O. Xćia Jmśći przez JJchmść Xięży Missyonarzów Zakonu Kaznodźieyskiego w Roku teraznieyszym 1762. odprawioney.

${ }^{109}$ AGAD, AR, dz. VI, sygn. II-80a, s. 219.

${ }_{110}$ M. Matuszewicz, op. cit., t. 1, s. 112.

${ }^{111}$ Ibidem, t. 2, s. 20-21.

112 A.B. Dobrowolski, Historja naturalna lodu, Warszawa 1923, s. 847-905; E. Stenz, O zjawiskach halo (cześć I), „Wiadomości Meteorologiczne” 1922, nr 2, s. 16-17; idem, O obserwacjach zjawisk halo, „Wiadomości Meteorologiczne” 1922, nr 4/5, s. 37-39; idem, Korespondencja Państwowego Instytutu Meteorologicznego. Ciekawe skojarzenie zjawisk halo, „Wiadomości Meteorologiczne” 
Ich występowanie jest typowe dla chmur Cirrostratus (warstwowo-pierzastych) i Cirrus (pierzastych) tworzących się od 5 do $13 \mathrm{~km}$ nad ziemią ${ }^{113}$. Zdaniem niemieckiego klimatologa Hansa Häckela kryształki lodu powodujące zjawisko słupów świetlnych powstają w temperaturze od ok. -4 do $-9{ }^{\circ} \mathrm{C}$ w warunkach dużej wilgotności, a kryształki sprzyjające powstaniu kręgu parhelicznego w temperaturze $-10^{\circ} \mathrm{C}^{114}$. Geofizyk Edward Stenz obserwował słupy świetlne w Zakopanem 23 stycznia $1933 \mathrm{r}$. przy temperaturze $-15^{\circ} \mathrm{C}$ i wilgotności $90 \%{ }^{115}$. Według klimatologów powstawaniu zjawisk halo sprzyjają też temperatury od -36 do $-56{ }^{\circ} \mathrm{C}^{116}$. Zjawiska te występują we wszystkich porach roku. Niewielka ilość relacji może być wytłumaczona trudnościami patrzenia na Słońce gołym okiem. Wymaga podkreślenia, że zjawiska pełnego pierścienia halo oraz słońc pobocznych są częstsze niż np. powszechnie znane zjawisko tęczy. Przy sprzyjających warunkach atmosferycznych mogą powstawać nawet codziennie ${ }^{117}$. Nie zawsze jednak są na tyle intensywne, by zwrócić uwagę, dlatego też należy sądzić, że zjawiska halo odzwierciedlone w źródłach musiały być bardzo wyraźne.

Opisy zjawisk $\mathrm{w}$ omawianych materiałach świadczą o próbie racjonalnego ich wytłumaczenia. Nie odbiegały one od informacji zawartych w ówczesnych traktatach naukowych bądź kompendiach wiedzy ${ }^{118}$, uznawano je powszechnie za „reperkusyjne” odbicie promieni słonecznych na chmurach.

Z pamiętnika Krzysztofa Zawiszy znany jest opis obserwacji dziwnych dla autora zjawisk odnotowanych pod rokiem 1721: „komety w Polsce i Litwie widziane były"119. Analiza tekstu skłania ku stwierdzeniu, że Zawisza opisał we

1924, nr 3/4, s. 58-59; idem, Ziemia. Fizyka globu, mórz i atmosfery, Warszawa 1936, s. 225-235; idem, Zjawiska optyczne w atmosferze, Łódź 1950, s. 25-33; R. Greenler, Tęcze, glorie i halo czyli niezwykłe zjawiska optyczne w atmosferze, przeł. M. Krzyżanowska, Warszawa 1998, s. 33-113; Słownik meteorologiczny..., s. 114; H. Häckel, Pogoda i klimat, przeł. M. Skalska, Warszawa 2009, s. 74-85.

${ }^{113}$ Według Doroty Matuszko ich powstawaniu mogą towarzyszyć także niekiedy chmury Altocumulus (średnie kłębiaste) oraz Stratus (niskie warstwowe). D. Matuszko, Chmury i pogoda, Kraków 2009, s. 45 (tabela 6. Meteory właściwe rodzajom chmur).

${ }^{114}$ H Häckel, op. cit., s. 79.

${ }^{115}$ E. Stenz, Zjawiska optyczne..., s. 39.

${ }^{116}$ D. Matuszko, op. cit., s. 12.

117 Stwierdzenie na podstawie własnych obserwacji. Podobne wnioski przedstawił Robert Greenler (op. cit., s. 47).

118 G. Rzączyński, Historia naturalis curiosa..., s. 420-421; idem, Auctuarium..., s. 497; W. Bystrzonowski, Informacja matematyczna rozumie ciekawego Polaka świat cały, niebo, y ziemię, y co na nich jest $w$ trudnych kwestyach y praktyce, jemuż ułatwiajace, Lublin 1743 (Informacya astronomiczna. O niebieskich luminarzach, y ich niebiosach, Informacya II, O słońcu, [punkt] XXI); B. Chmielowski, Nowe Ateny..., cz. 1, Lwów 1754, s. 165; K. Wyrwicz, Geografia czasow teraznieyszych albo opisanie naturalne y polityczne Krolestw, Państw, Stanow wszelakich, ich rzadu, praw, rzemiost, handlu, przemystu, przymiotow, obyczaiow \& c. ku pozytkowi narodowey młodzi wydana, t. 1, Warszawa 1768, s. 35.

119 Pamiętniki Krzysztofa Zawiszy..., s. 358. 
fragmencie trzy różne relacje o zjawiskach przyrodniczych, przy czym dwa z nich znał „ze słyszenia” i nie potrafił podać dokładnej daty obserwacji, natomiast ostatnie widział osobiście. Dwa pierwsze opisy dotyczą zorzy polarnej i omówię je w dalszej części. Ostatnia relacja jest owocem osobistej obserwacji pamiętnikarza, znamy miejsce wydarzenia i datę. 2 marca w powiecie brasławskim od południa do wieczora Zawisza widział trzy słońca. Prawdziwe Słońce znajdowało się w środku, zaś „z obu stron” dostrzegł dwa „nie reperkusyjne [!]” rzekome „słońca”. Pamiętnikarz stwierdził, że zjawiska były „nie reperkusyjne [!]”, gdyż wizualnie sprawiały wrażenie jednakowej jasności jak Słońce. Uznał więc, że zaobserwowane boczne „słońca” nie mogą stanowić „,reperkusji”, czyli odbicia promieni. Z powodu intensywnego blasku musiały być - zdaniem Zawiszy - podobnie jak Słońce źródłem światła. Od dwóch bocznych „słońc” odchodziły „promieniste figury [...] na boki i w dół”. Opis wskazuje na to, że Zawisza widział bardzo intensywne zjawisko słońc pobocznych $\mathrm{z}$ fragmentem łuku parhelicznego, a być może także z częścią pierścienia halo. Pamiętnikarz nadał swojej relacji tajemniczą atmosferę, o czym świadczy zdanie kończące relację, wyrażające niepokój spowodowany brakiem umiejętności właściwego odczytania intrygującego prognostyku i wynikającej stąd niepewności przyszłych czasów.

Relacje o obserwacjach słońc pobocznych odnajdujemy w kronikach witebskich. 26 marca 1704 r. „trzy słońca widziane były rano: które po prawey stronie było, te wprzód zginęło, a co po lewey stronie, to nie prentko [!]”120. Pięć lat później dwa intensywne zjawiska słońc pobocznych dostrzeżono w czasie niespełna dwóch tygodni. Mianowicie 7 stycznia 1709 r. „widziane były trzy słońca na zachodzie”, a także 19 stycznia „widziane były dwa słupy na połudzień, a słońce było we szrodku"121. Marcin Matuszewicz, który zaobserwował zjawisko słońca pobocznego w 1744 r. koło Gródka, podczas powrotu z Kowna z sejmiku gromnicznego, pokusił się o szacunkowe określenie odległości między słońcem właściwym a pobocznym („na kroków circiter 30 według oka naszego odległe") ${ }^{122}$.

Wśród doniesień o innych fotometeorach odnalazłem tylko jedną wzmiankę o obserwacji tęczy. Relację odnotował w swoim pamiętniku Marcin Matuszewicz, który w 1743 r. jadąc nocą z Wysokiego do Rasnej, widział około północy tęczę na niebie. Prawdopodobnie niezwykła pora obserwacji (noc) spowodowała tak wielkie zdziwienie pamiętnikarza, że nie omieszkał o tym wspomnieć, zaznaczył

${ }^{120}$ Витебская летопис составленная мещанами: Михаилом Панцырнымб (896-1709), Иваномъ Чарновскимъ (1601-1757), Гавріилом и Стефаномь Аверками (1578-1768), w: Сборникъ летописей относящзися къ исторіи южной и западной Руси, изданный Коммиссіею для разбора дневнихъ актовъ, состоящей при Кіевскомъ, Подольскомъ и вольнскомъ Генераль-Губернаторе, Кіевъ 1888, s. 224.

${ }^{121}$ Ibidem, s. 229.

${ }^{122}$ M. Matuszewicz, op. cit., t. 1, s. 219. 
przy tym, że „Noc nawet nie była barzo jasna” ${ }^{23}$. Brak dokładnej daty obserwacji świadczy, że opis nie powstał „na bieżąco", ale wygląd zjawiska został odtworzony po dłuższym czasie. Zjawisko wystąpienia tęczy nocą powstaje na takich samych zasadach jak w dzień, polega na odbiciu, załamaniu i rozszczepieniu na barwy widma światła w kroplach wody znajdujących się w atmosferze ziemskiej po przeciwnej stronie nieba niż Słońce lub Księżyc ${ }^{124}$.

Zjawisko przejściowego, kilkudniowego topnienia śniegu i lodu, stanowiącego zazwyczaj rezultat adwekcji ciepłego powietrza, w źródłach było nazywane „odwilżą"125, „odlidą"126, „odmiękczą"127, „rezolucją"128, „rozcieczą" ${ }^{29}$, „rozcieczami”"130 „roztoczą"131, „roztokami” ${ }^{132}$, „rostokami”"133, „zelżeniem”"134. Należy zwrócić jednak uwagę, że „rezolucją” określano również powrót mrozów. Tendencją relacji jest narzekanie na warunki jazdy podczas odwilży. W diariuszu Stanisława Niezabitowskiego znalazł się opis odwilży w dniach 9-19 stycznia 1699 r. w północno-wschodniej części województwa nowogródzkiego ${ }^{135}$. Przekaz ten jest wyjątkowy, zawiera bowiem codzienną rejestrację zjawisk pogodowych w perspektywie aż dziesięciodniowej (dzień po dniu), najdłuższej ze znanych źródeł litewskich z omawianej epoki. We wspomnianym opisie odwilży, który nie stanowi co prawda zapisu obserwacji z jednego miejsca, ale z kilku różnych, Niezabitowski dzień po dniu przedstawił bolączki i frustracje wynikające z intensywnych opadów deszczu, przejazdów topniejącymi śniegami, zmarzniętą drogą, gołoledzią oraz błotami, w których „mało konie i wozy się nie potopiły”. Warunki pogodowe wymuszały przemieszczanie się $\mathrm{w}$ stosunkowo krótkim czasie zarówno pojazdami kołowymi, jak również saniami.

Marcin Matuszewicz zamierzał wykorzystać odwilż po zapustach $1762 \mathrm{r}$. (ostatni dzień przed Wielkim Postem przypadł wówczas 23 lutego), by zwabić skonfliktowanego ze sobą magnata i być może rozpocząć proces pojednawczy. Jak wspominał: „podówczas była rezolucja drogi”, która spowodowała, że na brodzie pod Wołkowyczami nastąpił przybór wody. Korzystając z niemożności przejazdu

${ }^{123}$ Ibidem, s. 213.

${ }^{124}$ Por. Słownik meteorologiczny..., T108, s. 339.

125 AGAD, AR, dz. VI, sygn. II-81, k. 227v (5 XII 1750); Z Wilna 26. Marca, „Kurier Litewski” 1763, nr 13, Supplement do gazet wileńskich.

${ }^{126}$ AGAD, AR, sygn. II-80a, s. 1771.

127 S. Niezabitowski, op. cit., s. 140 (17 I 1697, Jatra-Starojelna), s. 222 (30 I 1699, Słuck).

${ }^{128} Z$ Z Wilna d. 27. Januarii, „Kuryer Polski” 1737, nr 6; M. Matuszewicz, op. cit., t. 2, s. 18.

${ }^{129}$ S. Niezabitowski, op. cit., s. 146 (24 III 1697, Nowogródek-Jatra).

${ }^{130}$ M. Matuszewicz, op. cit., t. 1, s. 638 (po 19 III 1756, Bobcin-Białystok).

${ }^{131}$ K. Bartoszewicz, op. cit., s. 30.

132 M. Matuszewicz, op. cit., t. 1, s. 99, 755 (1757, podróż do Nieświeża).

${ }^{133}$ Pamiętniki Krzysztofa Zawiszy..., s. 50 (14 III 1697).

${ }^{134}$ BTNP, rkps 113, k. 107v.

${ }^{135}$ S. Niezabitowski, op. cit., s. 220-221. 
przez bród kanclerza wielkiego litewskiego Michała Fryderyka Czartoryskiego wracającego z Białegostoku z zapustów, Matuszewicz zamierzał nakłonić magnata do objechania brodu i przemieszczania się przez należące do siebie dobra rasieńskie, co mogło być pretekstem gościny u pamiętnikarza, ale zanim jeszcze kanclerz nadjechał, „mróz wielki nastąpił”, który wzmocnił bród, umożliwiając bezpieczny przejazd kawalkady Czartoryskiego ${ }^{136}$. Z odwilżą wiążą się również niepowodzenia myśliwskie. Franciszek Szyrma wspominał obławę z psami 15 lutego 1707 r., w której uczestniczył w swojej rodzinnej Pińszczyźnie z Dominikiem Terleckim i nieznanym z imienia Brzeskim, ale że „śnieg zginął zaraz”, tropienie zwierzyny stało się niemożliwe ${ }^{137}$. Podobnie Michał K. Radziwiłł polujący na północnych rubieżach powiatu mozyrskiego 25 lutego 1750 r. powrócił do Moroczy po zupełnym fiasku obławy, która nie zastała drapieżnika w mateczniku, „bo śnieg zginoł [!] i woda podeszła, niedźwiedzia ruszyła" 138 .

W omawianym materiale znajdujemy informacje o nadzwyczajnie ciepłych zimach. Posesjonat piński Franciszek Szyrma pisał, że zima w 1721 r. okazała się „niecnotliwa”. Tegoroczne lato w powiecie pińskim było późne i mokre, co spowodowało opóźnienie żniw i sianie oziminy do 6 września (święto św. Michała według kalendarza juliańskiego). Opady śniegu czy mrozy nie wystąpiły aż do marca. $Z$ powodu ogromnych rozlewisk nie można było pozyskać drzewa z lasów ani siana dla zwierząt. Warunki pogodowe stały się dotkliwie odczuwalne dla ludzi ze względu na utrudnienia przewozowe i temperatury przyczyniające się do utrzymywania się stanu permanentnej wilgotności: „barzo się naprzykrzyła gołoledzią i zelżeniem, że nam nie przyszło ni razu sankami jeździć"139. Nietypowa była również zima w 1737 r. w powiecie brzeskim. W pierwszym tygodniu lutego Karol Wieszczycki pisał do Anny Radziwiłłowej z Brześcia: „Śniegów tu absolutnie nie masz, i drogi, ani sannej ani wozowej, bo się na brodach łamie” 140 . Z 1759 r. pochodzi doniesienie o „niestatecznej” zimie z okolic Witebska. Gwałtowne zmiany temperatury i warunków pogodowych, „wichry” i deszcze były przyczyną zalegania towarów, których transport uniemożliwiały „niesposobne” drogi, oprócz tego nastąpiło „zagęszczenie” się różnych chorób ${ }^{141}$.

Okresy intensywnych opadów deszczu to jedne z najczęstszych zjawisk spotykanych w źródłach. Do najbardziej deszczowych (opad trwający dłużej niż dwa tygodnie) należały m.in. lipiec 1718 r. (Wilno) ${ }^{142}$, czerwiec - wrzesień $1731 \mathrm{r}$.

\footnotetext{
${ }^{136}$ M. Matuszewicz, op. cit., t. 2, s. 192.

137 BTNP, rkps 113, k. 92.

${ }^{138}$ AGAD, AR, dz. VI, sygn. II-80a, s. 1702.

139 BTNP, rkps 113, k. 107v.

${ }^{140}$ K. Wieszczycki do A. Radziwiłłowej, 6 II 1737, z Brześcia, AGAD, AR, dz. V, sygn. 17362/I, s. 103.

${ }^{141}$ Z Witebska d. 11. Februarii, „Kuryer Polski” 1759, nr 9.

142 „Poczta Królewiecka” 1718, nr 2, s. 16.
} 
(Grodno, Wilno, Witebsk) ${ }^{143}$, maj - czerwiec 1751 r. (Wilno, Nieśwież) $)^{144}$ i ostatnia dekada sierpnia - pierwsza dekada października 1758 r. (Nieśwież) ${ }^{145}$. Przychodzący po okresach upałów i susz deszcz był odbierany jako błogosławieństwo boskie, upragniona i oczekiwana odpowiedź na nabożeństwa suplikacyjne ${ }^{146}$. Znaczny opad deszczu sprzyjał spławności rzek („defluitacji”) i co się z tym wiązało - możliwościom eksportowym ${ }^{147}$. W skrajnie odmiennych warunkach deszcz stawał się przyczyną szkód w płodach rolnych, a w konsekwencji drożyzny ${ }^{148}$, utrudniał bądź uniemożliwiał prace polowe ${ }^{149}$. Utrzymująca się wilgotna i deszczowa pogoda prowadziła do rozwijania się chorób wśród ludzi i zwierząa ${ }^{150}$. Konsekwencją intensywnych opadów deszczu był podniesiony stan wód prowadzący do wylewów i powodzi ${ }^{151}$. Obfite deszcze niszczyły i tak nie najlepsze drogi ${ }^{152}$, utrudniały, opóźniały bądź uniemożliwiały podróż ${ }^{153}$, zakłócały codzienne zajęcia i rozrywkę ${ }^{154}$. Ingerowały również w rozmaite czynności przeprowadzane na dworze. Omawiane źródła mówią np. o zakłóceniu przez deszcz toku pracy komisji granicznych ${ }^{155}$, a także o uniemożliwieniu odprawienia nabożeństw religijnych na zewnątrz świątyń ${ }^{156}$.

$\mathrm{Z}$ omawianym zjawiskiem wiąże się również „słota”, rozumiana jako długotrwały stan aury cechujący się intensywnym mniej lub bardziej natężonym

${ }^{143}$ Z Witebska d. 30. May, „Kuryer Polski” 1731, nr 78, s. 339; Z Wilna d. 15. Iuly, „Kuryer Polski” 1731, nr 83, s. 357; Z Witebska d. 8. Aug., „Kuryer Polski” 1731, nr 88, s. 371; Z Grodna d. 16. 7bris, „Kuryer Polski” 1731, nr 92, s. 395; Z Wilna d. 12. 7bris, „Kuryer Polski” 1731, nr 93, s. 400.

${ }^{144} Z$ Wilna d. 12. Junji, „Kuryer Polski” 1751, nr 770; Z Wilna d. 26. Junji, „Kuryer Polski” 1751, nr 772; AGAD, AR, dz. VI, sygn. II-80a, s. 1790.

${ }^{145}$ AGAD, AR, dz. VI, sygn. II-80a, s. 2170-2171, 2177.

${ }^{146}$ Z Wilna D. 27. Maja, „Kurier Litewski” 1763, nr 22; S. Niezabitowski, op. cit., s. 149 (29 IV 1697, Jatra).

${ }^{147} Z$ Grodna d. 16. 7bris, „Kuryer Polski” 1731, nr 92, s. 395.

${ }^{148} Z$ Wilna d. 12. 7bris, „Kuryer Polski” 1731, nr 93, s. 400; Z Wilna d. 19. Aug., „Kuryer Polski” 1741, nr 247.

149 „Poczta Królewiecka” 1718, nr 2, s. 16 (24 VII 1718); Z Wilna d. 15. Iuly, „Kuryer Polski” 1731, nr 83, s. 357; Z Witebska d. 8. Aug., „Kuryer Polski” 1731, nr 88, s. 371; Z Wilna d. 13. Sept., „Kuryer Polski” 1733, nr 196, s. 49; Z Wilna d. 12. Junji, „Kuryer Polski” 1751, nr 770; S. Niezabitowski, op. cit., s. 242 (10 VIII 1699, Słuck); Pamiętniki Krzysztofa Zawiszy..., s. 69 (16 VIII 1699, Rohotna).

150 „Poczta Królewiecka” 1719, nr 37, s. 296 (20 VIII 1719); Z Wilna d. 26. Junji, „Kuryer Polski” 1751, nr 772; Z Brześcia dnia. 26. Listopada, „Kuryer Polski” 1755, nr 124; AGAD, AR. dz. VI, sygn. II-80a, s. 2171 (22 IX 1758).

${ }^{151} Z$ Witebska d. 30. May, „Kuryer Polski” 1731, nr 78, s. 339.

${ }^{152}$ S. Niezabitowski, op. cit., s. 188 (23 III 1698, Malewo-Bielewicze).

153 Ibidem, s. 163 (31 VII 1697, Świsłocz-Iwaszkiewicze), s. 171 (1 XI 1697, Jatra-Sielec), s. 196 (13 VI 1698, Sielec-Pieski), s. 241 (25 VII 1699, Wilno-Błotna).

154 BPAN-PAUKr, sygn. 977, k. 114 (29 VIII 1701, Kuzawka); AGAD, AR, dz. VI, sygn. II-80a, s. 1922 (11 VIII 1753, Nieśwież); s. 1924 ( 27 VIII 1753).

155 Z Brześcia Litewskiego d. 21. Oct., „Kuryer Polski” 1731, nr 96, s. 412.

${ }^{156}$ AGAD, AR, dz. VI, sygn. II-80a, s. 2177 (8 X 1758, Nieśwież). 
deszczem ${ }^{157}$ (np. „pluchoty jesienne”) ${ }^{158}$, a także opadami deszczu ze śniegiem ${ }^{159}$. Nazywając utrzymujące się deszczowe warunki, stosowano również często określenie „niepogoda” ${ }^{160}$ bez sprecyzowania, o jakiej sytuacji atmosferycznej mowa. Tendencja ta jest widoczna w źródłach ${ }^{161}$. Intensywne deszcze w kwietniu $1745 \mathrm{r}$. stały się przyczyną tego, że 25 kwietnia Michał K. Radziwiłł zdecydował się na odłożenie uroczystego wjazdu do Wilna na sesję Trybunału. Wjazd miał się odbyć następnego dnia i być manifestacją siły wobec stronnictwa Czartoryskich, ale „dla wielkiej niepogody" Radziwiłł czekał w swoim pałacu w Niemieży na poprawienie aury („,azali się niewypogodzi”), przyjmując przybywających z wizytami przedstawicieli elit dygnitarsko-urzędniczych i okolicznej szlachty. Wjazd zorganizowany z wielką pompą odbył się 29 kwietnia $^{162}$.

Wylewy rzek i powodzie stanowiły skutek wiosennych roztopów, zatorów lodowych bądź śryżowych koryt rzecznych oraz intensywnych deszczy, w konsekwencji prowadzących do zalania pól uprawnych, zniszczenia plonów, zagłady domostw i gospodarstw ${ }^{163}$. Były one typowe dla wiosny i jesieni, czasem lata, ale zdarzały się również zimą. Zepsuciu ulegały drogi, duże wody znosiły mosty i niszczyły brody i groble. Tereny z szeroko rozlaną wodą były siedliskiem bakterii i przyczyniały się do plag insektów. Bezpośrednim następstwem powodzi stawały się wzrastające ceny płodów rolnych oraz siana. Intensywność zjawiska na określonym terenie

157 Pamiętniki Krzysztofa Zawiszy..., s. 159 (31 VIII 1713, Bakszty), s. 162 (przełom IX i X 1714, okolice Słonima); AGAD, AR, dz. VI, sygn. II-80a, s. 1012 (27 IX 1739, Nieśwież), s. 1604 (20 IX 1748, Szczytno-Sielec); Wilhelma Schlemüllera Dyarysz podróży polskiej na sejm grodzieński Roku Pańskiego 1752 odbytej z rękopisu Archiwum Królewieckiego na widok publiczny przez Wacława Gizberta-Studnickiego archiwariusza miasta Wilna wydany dla użytku rodaków z łacińskiego na język polski przetłumaczył x. kanonik J. Rosołowski, „Litwa i Ruś. Miesięcznik ilustrowany, poświęcony kulturze, dziejom, krajoznawstwu i ludoznawstwu”, IV 1912, t. 2, z. 1, s. 27 (21 X 1752, okolice Kalwarii).

${ }^{158}$ M. Matuszewicz, op. cit., t. 2, s. 123 (1760).

${ }^{159}$ Pamiętniki Krzysztofa Zawiszy..., s. 155 (23-30 X 1711, Nowojelna - okolice Ochonowem - wieś Pogiry).

${ }^{160}$ W. Kupiszewski, Słownictwo meteorologiczne $w$ gwarach $i$ historii języka polskiego, WrocławWarszawa-Kraków 1969, s. 39, 119.

${ }^{161}$ Z Słonima dnia 29 Lutego, „Kuryer Polski” 1756, nr 138; Z Wilna dnia 27. Augusta, „Kuryer Polski” 1759, nr 38, Addytament do gazet; $Z$ Wilna d. 16 Pazdźiernika, „Kurier Litewski” 1761, nr 42; AGAD, AR, dz. VI, sygn. II-80a, s. 477 (Korelicze, 16 II 1732), s. 439 (14 VII 1731, BiałaMir-Korelicze), s. 987 (21 V 1739, Biała p. Nieświeżem), s. 993 (16 VI 1739, Korelicze), s. 1241 (20 IV 1743, Korelicze i okolice), s. 1316 (30 VI 1744, okolice Brześcia), s. 1360-1361 (24-29 IV 1745, Niemieża-Wilno), s. 1790 (8 VI 1751, Nieśwież), s. 1837 (17 III 1752, Łachwa), s. 1841 (9 IV 1752, Nieśwież), s. 1923 (21 VIII 1753, Korelicze), s. 2018 (18 IX 1755), s. 2019 (25 IX 1755), s. 2051 ( 29 V 1756), s. 2062 (13 VIII 1756, Nieśwież), s. 2063 (15 VIII, 20 VIII 1756, Nieśwież), s. 2093 (1 V 1757, Nieśwież), s. 2225 (26 III 1759, Korelicze), s. 2230 (17 V 1759, Nieśwież), s. 2231 (18 V 1759, Nieśwież), s. 2314 (18 VII 1761, Nieśwież-Biała).

162 AGAD, AR, dz. VI, sygn. II-80a, s. 1360-1361.

${ }^{163}$ Витебская тетопис..., s. 223 (1700, Witebsk); Z Witebska d. 30. May, „Kuryer Polski” 1731, nr 78 , s. 33. 
mogła skutkować klęską głodu zarówno ludzi, jak i zwierząt, a co za tym idzie wysoką częstotliwością pomorów. Franciszek Jukniewicz stwierdził, że wiosenne powodzie na Litwie miały miejsce w latach: $1699,1701,1714,1716,1736,1740^{164}$.

Podczas wylania Dniepru w kwietniu 1731 r. pływano czółnem do samej furty i drzwi kościoła oo. Bernardynów w Mohylowie ${ }^{165}$. „Kuryer Polski” wspominał wylanie Dźwiny w kwietniu 1732 r., redaktor zauważył, że wysoki stan wód znacznie ułatwił żeglugę, jednak w tymże roku do Rygi popłynęło zaledwie kilkadziesiąt statków, gdy w innych latach z płodami rolnymi żeglowało ich corocznie kilkaset. Tłumaczono to przeszłorocznym nieurodzajem. Prognozy dotyczące obecnych zbiorów również nie były optymistyczne z uwagi na "mrozy y wiatry zimne” 166 . Franciszek Szyrma pozostawił sugestywny opis powodzi w powiecie pińskim w 1728 r.: „Powódź wielka odjęła grunta. Żyta koszono z mietkią straszenną. Ogrody wymokły z nasion ogrodnych. Jarzyny także w polach. Czółnami [jak] po stawie jeżdżono. Całe lato mokre, we dźdźach [!] ustawicznych. Ryby zginęły po wodach w całym Zarzeczu. Ptastwo ponikło. Ogołocił Pan Bóg szlachtę i chłopów, tak dalece żeśmy nie mieli czego jeść. Cebulę, kapustę przykupić musiałem. Łąki niekoszone niektóre co woda zalała"167. Dominikanin o. Wojciech Bagiński wspominał, że w Wilnie 1761 r. miała miejsca „powódź wielka”, woda zalewała spichlerze i domy. Szkody oceniono na milion złotych polskich ${ }^{168}$.

W źródłach spotykamy również szereg uwag dotyczących niedogodności podróży wynikających z wylewów, bolączką były nieprzejezdne trasy i opóźnienia wynikające z jazdy okrężną, często nieznaną drogą, trudności związane z przeprawą przez rozlewiska itp. ${ }^{169}$ Karol Wieszczycki, po przeprowadzonej wizytacji radziwiłłowskich dóbr nadbużańskich w powiecie brzeskim w okolicy Sławatycz, 30 czerwca 1736 r. pisał do Anny z Sanguszków Radziwiłłowej o narzekaniach osadników holenderskich, że „,woda ekstraordynaryjnie wielka pozatapiała pastwiska”, w związku z czym prosili o zgodę na przeprowadzenie transakcji handlowej, której dochód przeznaczony zostałby na codzienne potrzeby ${ }^{170}$.

\footnotetext{
${ }^{164}$ F. Jukniewicz, op. cit., s. 66.

165 Z Biátey Ruśi d. 1. May, „Kuryer Polski” 1731, nr 73, s. 314.

${ }^{166} Z$ Witebska d. 30. April., „Kuryer Polski” 1732, nr 126, s. 137.

167 BTNP, rkps 113, k. 116.

${ }^{168}$ Rękopism x. Bagińskiego dominikana Prowincyi Litewskiéj (1747-1784 r.) wydany przez E. Tyszkiewicza, Wilno 1854, s. 33.

169 Путешествіе..., „Русскїй Архивъ” 1888, nr 2, s. 174 (6 IV 1697, okolice Żdanowicz); Pamiętniki Krzysztofa Zawiszy..., s. 67 (27 III 1697, Kurkle); S. Niezabitowski, op. cit., s. 241 (25 VII 1699, Wilno-Błotna), s. 269 (4 IV 1700, Klepczany), s. 270 (21 IV 1700, Iwieniec-Wołożyn); BPAN-PAUKr, sygn. 977, k. 163 (6 IV 1705, okolice Mira); AGAD, AR, dz. VI, sygn. II-80a, s. 1360 (21 IV 1745, nad Niemnem w okolicy Mikołajewa), s. 1838 (27 III 1752, okolice nad Niemnem), s. 1956 (23 IV 1754, okolice Iwia, rejon nadniemeński).

${ }^{170}$ K. Wieszczycki do A. Radziwiłłowej, 30 VI 1736, z Jabłecznej, AGAD, AR, dz. V, sygn. 17362/I, s. 73-74.
} 
Klęską żywiołową budzącą powszechną trwogę, wymienianą w znanym hymnie suplikacyjnym obok zarazy, pożaru i wojny, był głód. W omawianych źródłach znalazły odzwierciedlenie największe głody obejmujące swoim zasięgiem znaczne obszary Wielkiego Księstwa. Franciszek Jukniewicz wymienił lata głodu na Litwie: $1697,1702,1708,1710,1715,1718^{171}$. W źródłach została odnotowana też klęska głodu w latach 1736-1737.

O głodzie, który dotknął województwo wileńskie i Żmudź w czasie działań wojennych w 1710 r., pisali bazylianin o. Jan Oleszewski i Krzysztof Zawisza. Deficyt żywności spowodowały rekwizycje wojskowe, dezolacja oraz grabieże majątków i gospodarstw. Powszechny kryzys stał się konsekwencją degeneracji społecznych. Miały miejsce przypadki kanibalizmu, jak przytoczony przez bazylianina Oleszewskiego mord dokonany przez chłopa we wsi Chołchle w powiecie oszmiańskim, kiedy martwym ciałem ofiary żywiła się żona i dzieci zabójcy. Niedojedzone szczątki ludzkie odnalezione w domu mordercy stały się przyczyną spalenia jego i żony na stosie na podstawie wyroku sądowego ${ }^{172}$. Znane są $\mathrm{z}$ tego okresu nagminne przypadki zjadania padliny zdechłych zwierząt, a nawet zwłok ludzkich, które w znacznej ilości poniewierały się przy drogach oraz „po niespodzianych miejscach"173. Powszechnie jedzono zwierzęta domowe, a Zawisza wspomniał o zjadaniu dzieci przez matki „na kilku miejscach”, nie podał jednak przykładów z ziem litewskich ${ }^{174}$. Obrazy śmierci głodowych i ludzi zamarzłych byle gdzie podczas zimowych mrozów dopełniały bieda i utrata nadziei. Powszechne były napady na podróżnych, zdradzieckie podcinanie pęcin końskich, co uniemożliwiało dalszą jazdę. Unieruchomione zwierzęta porywano i zjadano. W opisie Oleszewskiego pozostało wspomnienie posępnych wsi i miasteczek z korowodami włóczących się gromad zabiedzonych nieszczęśników „srodze od głodu zbolałych, spuchłych y ięczących [...], noszących obrazy śmierci na sobie" 175 .

Autor obszernej relacji wspominał, że w Wilnie zwłoki tragicznie zmarłych były wywożone za bramy miasta i zakopywane w zbiorowych mogiłach ${ }^{176}$. Zawisza twierdził, że w Wilnie umierało wówczas więcej niż 100 osób dziennie, wywodzących się głównie $\mathrm{z}$ warstw najuboższych ${ }^{177}$. Potworna nędza i ogrom nieszczęść były przyczyną fali uchodźstwa całych osiedli ludzkich głównie na Wołyń i ziemie ukrainne. Oleszewski zwrócił uwagę, że na Żmudzi wsie i miasteczka „w pustynię się poobracały" ${ }^{\prime 78}$. O powszechnym wówczas uchodźstwie z północnych terenów

\footnotetext{
${ }^{171}$ F. Jukniewicz, op. cit., s. 67.

172 Abrys..., s. 79.

173 Ibidem.

174 Pamiętniki Krzysztofa Zawiszy..., s. 364.

${ }^{175}$ Abrys..., s. 79.

176 Ibidem.

177 Pamiętniki Krzysztofa Zawiszy..., s. 364.

${ }^{178}$ Abrys..., s. 79.
} 
Wielkiego Księstwa wspomniał również terrigena piński Franciszek Szyrma: „ludzie, jak woda płynęli stamtąd w kraj piński ${ }^{179}$.

Fala głodu dotknęła ziemie litewskie, ale też tereny całej Rzeczypospolitej w latach 1736 i 1737, co zapoczątkowała klęska powodzi w różnych rejonach państwa $^{180}$. Karol Wieszczycki wizytujący radziwiłłowskie nadbużańskie Sławatycze, 18 kwietnia 1736 r. pisał do Anny z Sanguszków Radziwiłłowej: „Poddaństwo tu bardzo mizerni, i z głodu wielu opuchło, dlaczego kazałem im dawać proporcjonalne żyta na chleb" ${ }^{181}$. W liście zawarł również prośbę o zgodę na wydawanie chłopom zboża "na chleb i na zasiew”182. Rok później, 28 lutego 1737 r. pisał o powszechnym braku pożywienia wśród ludności najuboższej: „jedni z głodu puchną, drudzy umierają, inni plewami i [o]młotem żyją" ${ }^{183}$.

Głód nie zawsze przybierał rozmiary klęski ogólnokrajowej. Częstym zjawiskiem był niedobór żywności na przednówku, wczesną wiosną w okresie oczekiwania na nowe plony, gdy spożytkowano zbiory z przeszłego roku. W kwietniu 1742 r. w województwie połockim "głód wielki” spowodował falę rozbojów ${ }^{184}$. W 1757 r. w powiecie brzeskim była „wiosna głodna”. Marcin Matuszewicz nie chcąc darmowo wydawać chłopom zboża, najmował ich do pracy przy zakładaniu ogrodu włoskiego; za otrzymane wynagrodzenie mogli nabyć zboże ${ }^{185}$.

Bolączką gospodarzy były okresy utrzymujących się wysokich temperatur. Przeciągające się ekstremalne upały stawały się przyczyną nieurodzajów i suszy. Gorącą i suchą porę letnią szkodzącą plonom dostrzegamy m.in. w latach 1719, $1720,1749,1751,1762^{186}$. W czerwcu 1762 r. z polecenia biskupa wileńskiego Ignacego Jakuba Massalskiego w kościołach wileńskich były celebrowane nabożeństwa "na odwrócenie pożarów, i suszy niepraktykowaney”"187. 17 czerwca $1762 \mathrm{r}$. zgodnie z obrządkiem grekokatolickim została odprawiona procesja Bożego Ciała, której intencją była prośba do Stwórcy o „zbytniey suszy oddalenie” ${ }^{188}$. Procesja, w czasie której czytano cztery ewangelie, wyszła z cerkwi św. Trójcy i przeszła po wszystkich kościołach. Podczas liturgii śpiewane były pieśni greckie i łacińskie.

\footnotetext{
179 BTNP, rkps 113, k. 96.

180 Por. AGAD, AR, dz. VI, sygn. II-80a, s. 780, 785 (dotyczy ziem koronnych).

${ }^{181}$ K. Wieszczycki do A. Radziwiłłowej, 18 IV 1736, ze Sławatycz, AGAD, AR, dz. V, sygn. 17362/I, s. 33.

182 Ibidem, s. 35.

${ }^{183} \mathrm{~K}$. Wieszczycki do A. Radziwiłłowej, 28 II 1737, z Wohinia, ibidem, s. 114.

${ }_{184} Z$ Połocka d. 11. April, „Kuryer Polski” 1742, nr 282.

${ }^{185}$ M. Matuszewicz, op. cit., t. 1, s. 819.

186 „Poczta Królewiecka” 1719, nr 28, s. 224 (18 VI 1719, Wilno); „Poczta Królewiecka” 1720, nr 31, s. 248 (30 VI 1720); Z Witebska d. 1. Aug., „Kuryer Polski” 1749, nr 674; Z Wilna d. 23. Aug., „Kuryer Polski” 1749, nr 676; Rękopism..., s. 22 (1751).

${ }^{187}$ Z Wilna dnia 12. Czerwca, „Kurier Litewski” 1762, nr 24, Supplement do gazet wileńskich, k. 1; Z Wilna 18 Czerwca, „Kurier Litewski” 1762, nr 25, k. 1v.

${ }^{188}$ Z Mińska 18. Czerwca, „Kurier Litewski” 1762, nr 26, k. 1v.
} 
Uczestniczyli w niej przedstawiciele wszystkich zakonów katolickich, a także cechy rzemieślnicze ze swymi chorągwiami. Niesiono słynący cudami obraz Najświętszej Maryi Panny. Chleb Eucharystyczny (Sanctissimum) trzymał jezuita. Nabożeństwo trwało do godz. $14^{189}$. Wysokie temperatury były w Wilnie już w maju tego roku. Marcin Matuszewicz wspominał 16 maja - dzień wjazdu biskupa wileńskiego Ignacego Jakuba Massalskiego na swoją stolicę: „Był barzo gorący ten dzień”. Uroczysty wjazd ordynariusza trwał od godz. 14 do 19. Według Matuszewicza warunki pogodowe stały się zgubne dla wojewody wileńskiego i hetmana wielkiego litewskiego Michała K. Radziwiłła, który „w tak gorący dzień i tak długo pieszo idąc, wszystek spotniały”, przeziębił się, wszedłszy do zimnego kościoła, co według pamiętnikarza stało się początkiem agonii ${ }^{190}$. Kilkudniowa choroba hetmana zakończyła się jego śmiercią rankiem 22 maja $^{191}$. Wiadomo, że Radziwiłł był bardzo schorowany, kilka miesięcy przed swoją śmiercią, po przebyciu ciężkich dolegliwości żołądkowych, napisał w swoim diariuszu: „trzeba się już Panu Zastempów [!] oddawać i czekać zmiłowania Jego" ${ }^{192}$. Możliwe, że ekstremalna temperatura wpłynęła na gwałtowne pogorszenie się stanu jego zdrowia. Do przyczyn śmierci hetmana nawiązał Matuszewicz w zredagowanym przez siebie Liście przyjaciela do przyjaciela, użytym w walce politycznej w 1763 r.: „upałem słońca strudzony, a potem wieczornym zimnem przejęty, zachorował i umarł”'193.

Wiadomo, że upały wpływają na samopoczucie. W sierpniu $1751 \mathrm{r}$. Michał K. Radziwiłł odnotował w diariuszu, że dzień 19 sierpnia był „Dla wielkiego gorąca, lubo pochmurny”. Warunki meteorologiczne spowodowały złe samopoczucie: „osłabiałem na fryzel [krostki - M.T.W.] i boję się róży [zapalenie skóry - M.T.W.] w nodze"194. Zrozumiałe jest, że podróżując w letnie upalne dni, pokonywano trasę chłodnym wieczorem i nocą, unikając skwaru ${ }^{195}$.

W czerwcu 1746 r. mała woda w Dźwinie w rejonie Witebska, spowodowana suszą, utrudniła spław przewożącym żołnierzy statkom moskiewskim. Część statków uległo zniszczeniu i 200 żołnierzy musiało maszerować lądem.

14 czerwca mieszkańcy Witebska byli świadkami dwugodzinnego przelotu wielkiego roju szarańczy ${ }^{196}$. Gromady szarańczy wędrownej (Locusta migratoria) ${ }^{197}$

\footnotetext{
${ }^{189}$ Ibidem.

${ }^{190}$ M. Matuszewicz, op. cit., t. 2, s. 205.

${ }^{191}$ Z Wilna dnia 22. Maja, „Kurier Litewski” 1762, nr 21, Supplement do gazet wileńskich.

192 AGAD, AR, dz. VI, sygn. II-80a, s. 2326.

${ }^{193}$ M. Matuszewicz, op. cit., t. 2, s. 330.

194 AGAD, AR, dz. VI, sygn. II-80a, s. 1805.

195 Ibidem, s. 1447 (13 VII 1746), s. 1859 (31 VII 1752, Ręczaje).

${ }^{196}$ Z Witebska d. 15. Jun., „Kuryer Polski” 1746, nr 500.

197 Ojczyzną tego gatunku szarańczowatych są stepy euroazjatyckie i afrykańskie. Osobniki osiągają wielkość 3,5-5,5 cm. Żywią się roślinnością. Samica składa co roku 100 jaj w ziemi, gdzie mogą przebywać nawet kilka lat. Skupiska jaj sprzyjają wylęganiu ogromnej liczby larw szarańczy $\mathrm{w}$ dogodnych warunkach i określonym miejscu. Wyczuwając zmiany pogodowe, podczas upałów
} 
nawiedzały ziemie polsko-litewskie w okresach suszy od średniowiecza (plaga owadów odnotowana została w źródłach w 1335 r.) $)^{198}$. W omawianej epoce inwazje szarańczy na terytoria litewskie miały miejsce w $1711^{199}, 1748^{200}$ i $1749 \mathrm{r}^{201}$ Przeloty owadów bez adnotacji źródłowej o wyrządzonych szkodach zostały zarejestrowane w 1741 (nad powiatem oszmiańskim) ${ }^{202}$ i 1746 r. (nad Witebskiem) ${ }^{203}$.

Określając ilość lecącej bądź żerującej na polach szarańczy, pisano: „niezliczona”204, „wielkie gromady”205, „niewypowiedziane mnóstwo” ${ }^{206}$, „wielkie mnóstwo"207, „moc wielka”208. Wyobrażenia o wielkości rojów, które bytowały na Litwie, dają opisy mówiące o czasie obserwacji chmar owadów, np. 14 czerwca 1746 r. lecący nad Witebskiem rój ciągnął się dwie godziny ${ }^{209}$. Szarańcza lecąca nad Mińskiem 14 sierpnia 1748 r. po południu zasłoniła słońce również na dwie godziny; ciekawe jest porównanie efektu dźwiękowego towarzyszącego przelotowi: „z hukiem niby wielkich młynów”. Autor relacji opisał masę owadów jak ciemną ścianę gradu zasłaniającą słońce, rozciągającą się między niebem a ziemią: „słońce záćmiła, bo jákby naywiększa gęstość gradu od ziemi ku Niebu przeyrzeć iey nie można było"210. Rój obserwowany nad Mińskiem stanowił zaledwie początek przelotu gigantycznych chmar owadów, które „iák nayciemnieysza chmura” przetaczały

i suszy osobniki osiągają fazę stadną, łączą się w gigantyczne roje i niezależnie od ilości pokarmu, jaki odnajdą, rozpoczynają wędrówkę powietrzną. Mogą przemieszczać się na odległość $3000 \mathrm{~km}$ (dziennie 100-200 km). Lot jest przerywany opadaniem roju na określone tereny, które zostają doszczętnie objedzone. Jeden osobnik zjada dziennie 2 g pożywienia. Milion owadów jest w stanie na raz pochłonąć tonę masy roślinnej. Nawet jeśli osobniki nie zjedzą wszystkiego w okolicy, to nadgryziona przez nie roślinność usycha. Roje szarańczy mogą osiągać gigantyczne rozmiary (nawet do 40 mld osobników). Jeden rój potrafi obsiąść nawet $1200 \mathrm{~km}^{2}$. W I ćwierci XX w. w Argentynie widziano chmarę owadów ciągnącą się na długości blisko $100 \mathrm{~km}$ i szeroką na ok. 20 km. Osobniki żyją 3 miesiące. H. Sander, Owady, Warszawa 1989, s. 235-236.

${ }^{198}$ M.H. Malewicz, Zjawiska przyrodnicze $w$ relacjach dziejopisarzy polskiego średniowiecza, Wrocław-Gdańsk 1980, s. 161 (aneks V); por. M.L. Wójcik, Chwile strachu i trwogi. Klęski żywiołowe, konflikty zbrojne i tumulty w średniowiecznym Wrocławiu, Racibórz 2008, s. 61.

199 Pamiętniki Krzysztofa Zawiszy..., s. 364.

${ }^{200}$ Z Brzescia Litewskiego d. 3. Aug., „Kuryer Polski” 1748, nr 613; Z Mińska d. 14. Aug., „Kuryer Polski” 1748, nr 614; Z Wilna d. 24. Aug., „Kuryer Polski” 1748, nr 615; AGAD, AR, dz. VI, sygn. II-80a, s. 1600-1601 (25 VIII, 27 VIII, 29 VIII 1748, Korelicze-Sobotniki-Mikołajewicze-Cetra).

${ }^{201}$ Z Wilna d. 19. April., „Kuryer Polski” 1749, nr 649; Z Wilna d. 7. Jun., „Kuryer Polski” 1749, nr 665; Z Rzeczycy d. 5. Jul., „Kuryer Polski” 1749, nr 671; AGAD, AR, dz. VI, sygn. II-81, k. 90v (13, 14 IX 1749, Biała i okolice, powiat brzeski), k. 94 (2, 3 X 1749, Biała i okolice).

${ }^{202}$ Z Wilna d. 10. Junij, „Kuryer Polski” 1741, nr 237.

${ }^{203} Z$ Witebska d. 15. Jun., „Kuryer Polski” 1746, nr 500.

${ }^{204}$ Z Wilna d. 10. Junij, „Kuryer Polski” 1741, nr 237.

${ }^{205} Z$ Wilna d. 24. Aug., „Kuryer Polski” 1748, nr 615.

${ }^{206}$ Z Mińska d. 14. Aug., „Kuryer Polski” 1748, nr 614.

${ }^{207}$ Z Wilna d. 7. Jun., „Kuryer Polski” 1749, nr 665.

${ }^{208}$ AGAD, AR, dz. VI, sygn. II-81, k. 94.

${ }^{209}$ Z Witebska d. 15. Jun., „Kuryer Polski” 1746, nr 500.

${ }^{210}$ Z Mińska d. 14. Aug., „Kuryer Polski” 1748, nr 614. 
się nad miastem przez następne pięć dni ${ }^{211}$. Zawisza wspominając plagę szarańczy w 1711 r., stwierdził: „Leciała jako mgła, że nieba znać nie było”212. Dominikanin o. Wojciech Bagiński pisząc o ilości szarańczy w 1748 r., powiedział: „Mnogość jéj tak była okropna, że zdjąwszy się z ziemi na powietrze, jasność słońca ćmiła”. Wspominał, że rój osiadający na ziemi zajmował przestrzeń ćwierć mili $(\text { ok. } 2 \mathrm{~km})^{213}$. Z kolei biskup diocezareński Józef J. Sapieha wspominając podróż z Wilna do Słonima 7 września 1748 r., pisał: „na siłu [!] miejscach widziałem pole okryte szarańczą, która w Polszcze i w Litwie tego roku grassowała"214.

Zwraca uwage nomenklatura militarna stosowana w odniesieniu do chmar owadów, przywodząca na myśl bezlitosne ogołacanie ze wszelkiego dobytku przez oddziały wojskowe. Zawisza pisał, że szarańcza „leciała pułkami”, co skojarzyło mu się z kolorami osobników z różnych grup. Owady miały kolory: zielone, czarne, szare i żółte ${ }^{215}$. Podobnie autor relacji z „Kuryera Polskiego”, opisując szarańczę grasującą w województwie brzeskolitewskim w lipcu i sierpniu 1748 r., zauważył, że leciała ona kilkoma „kolumnami” ze wschodu ku zachodowi i północy, a była zielona i czarna ${ }^{216}$. Michał K. Radziwiłł napisał, że podczas podróży pod koniec sierpnia 1748 r. w okolicy Mikołajewa widział „partię” szarańczy ${ }^{217}$.

Szarańcza objadała pola z wszelkiej roślinności. Krzysztof Zawisza, pisząc o inwazji owadów w 1711 r., twierdził, że plaga była jeszcze gorsza niż w 1690 r. $^{218}$ Szarańcza tam, gdzie wylądowała, „nic na polach nie zostawiła”. Owady zjadały ziarno zbóż, kłosy, a także słomę ${ }^{219}$. O tym, że szarańcza konsumowała nawet słomę, pisał również Bagiński, świadek plagi z $1748 \mathrm{r}^{220} \mathrm{Z}$ tego roku pochodzą też relacje o wyjadaniu do szczętu przez szarańczę wszelkiej roślinności polnej, traw, zbóż i liści na drzewach ${ }^{221}$. „Kuryer Polski” z 1749 r. donosił, że dobra starosty rzeczyckiego Albrechta Radziwiłła w województwie mińskim pustoszyły larwy szarańczy, chodząc $\mathrm{w}$ różne miejsca i wyjadając trawę „y zbożu gdzie nápadnie

\footnotetext{
${ }^{211} Z$ Wilna d. 24. Aug., „Kuryer Polski” 1748, nr 615.

${ }^{212}$ Pamiętniki Krzysztofa Zawiszy..., s. 364.

${ }^{213}$ Rękopism..., s. 9.

${ }^{214}$ BN, BOZ, sygn. 941, s. 493.

${ }^{215}$ Pamiętniki Krzysztofa Zawiszy..., s. 364.

${ }^{216}$ Z Brzescia Litewskiego d. 3. Aug., „Kuryer Polski” 1748, nr 613.

${ }^{217}$ AGAD, AR, dz. VI, sygn. II-80a, s. 1601.

${ }^{218}$ Plaga szarańczy w lipcu 1690 r. została odnotowana również w źródłach koronnych; wspominał ją proboszcz parafii Niedrzwica na Lubelszczyźnie, ks. Stanisław Albert Królikiewicz. BN, BOZ, sygn. 837, s. 184. W kronice klęsk żywiołowych, opracowanej przez Stanisławę Namaczyńską, brak informacji na temat inwazji szarańczy w tym roku na terenach Rzeczypospolitej (S. Namaczyńska, op. cit., s. 213).

${ }^{219}$ Pamiętniki Krzysztofa Zawiszy..., s. 364.

${ }^{220}$ Rękopism..., s. 9.

${ }^{221}$ Z Brzescia Litewskiego d. 3. Aug., „Kuryer Polski” 1748, nr 613; Z Mińska d. 14. Aug., „Kuryer Polski” 1748, nr 614; Z Wilna d. 24. Aug., „Kuryer Polski” 1748, nr 615.
} 
nie folguie"222. W tym samym roku, 3 października Hieronim F. Radziwiłł wyjeżdżając z Białej (powiat brzeski), widział chmary szarańczy: „znalazłem moc wielką szarańczy jajka w ziemię wpuszczającej, z której nowa pewnie będzie"223. Dominikanin o. Bagiński pisał, że gospodarze chcąc ochronić przynajmniej część plonów, zanim jeszcze rozwinęły się larwy szarańczy lub też rój dorosłych osobników nie obsiadł wszystkich pól, zbierali w pośpiechu niedojrzałe kłosy ${ }^{224}$.

Ogołociwszy okolicę z wszelkiej roślinności, roje szarańczy migrowały w kolejne rejony. Michał K. Radziwiłł zauważył w Sobotnikach (Subotnikach) w powiecie oszmiańskim w ostatniej dekadzie sierpnia 1748 r., że po spustoszeniu regionu chmary owadów przenosiły się w kierunku województwa trockiego ${ }^{225}$.

Gdy przechodziła pierwsza fala inwazji, podczas której znaczna część roślinności na polach została już spożytkowana, odnajdowano duże skupiska szarańczy w lasach. 27 sierpnia 1748 r. Michał K. Radziwiłł niedaleko Mikołajewa widział „wielką" liczbę owadów, które - jak twierdził - przebywały tu już od tygodnia, za co nie omieszkał podziękować Bogu ${ }^{226}$. Psy myśliwskie jego ojca, kanclerza wielkiego litewskiego Karola S. Radziwiłła, zamiast szukać tropów zwierząt, znalazły sobie osobliwą rozrywkę, ich właściciel uznał więc polowanie pod Terebelą w powiecie brzeskim 26 września 1711 r. za nieudane, „bez uciechy bo psy szarańczę goniły po kniei"227. Znam przykład wydania w 1749 r. polecenia podpalania lasów z zamiarem unicestwienia zgromadzonych $\mathrm{w}$ nich świeżo wylęgłych larw szarańczy w podwarszawskich dobrach (okolice Otwocka) marszałka wielkiego koronnego Franciszka Bielińskiego ${ }^{228}$. Na terenach litewskich nie zanotowano podobnego pomysłu, ale wśród informacji prasowych $\mathrm{z}$ tego samego roku czytamy enigmatyczne doniesienie: „około Mohylowa, gdzie wielkie mnostwo Szarańczy iuż młodey pokazało się, ktorey do wzrostu profuit panuiąca ciepłość náder sucha, á lubo puszcze wszędy powygorywały, przecie to insectum nie wyginęło"229.

Jak pisał o. Bagiński, próbowano odstraszać z pól szarańczę wystrzałami z armat i strzelb, napędzano na pola trzody świń, aby wyjadały owady, organizowano polewanie szarańczy wrzącą wodą. Jednak jak sam autor przyznawał, zabiegi te nie przynosiły spodziewanych efektów, gdyż nawet jeśli udało się poderwać jakąś część owadów do góry, za chwilę obsiadały one pole tuż obok ${ }^{230}$.

${ }^{222}$ Z Rzeczycy d. 5. Jul., ,Kuryer Polski” 1749, nr 671.

${ }^{223}$ AGAD, AR, dz. VI, sygn. II-81, k. 94.

${ }^{224}$ Rękopism..., s. 9.

${ }^{225}$ AGAD, AR, dz. VI, sygn. II-80a, s. 1600.

226 Ibidem, s. 1601.

${ }^{227}$ BPAN-PAUKr, sygn. 977, k. 244v.

${ }^{228}$ Z Warszawy d. 7. Maji, „Kuryer Polski” 1749, nr 660.

${ }^{229}$ Z Wilna d. 7. Jun., „Kuryer Polski” 1749, nr 665.

${ }^{230}$ Rękopism..., s. 9. 
Konsekwencją bytowania szarańczy były głód i drożyzna na płody rolne. Deficyt pożywienia dla zwierząt skutkował niejednokrotnie pomorem bydła i koni. „Kuryer Polski” w 1749 r. donosił o katastrofalnej sytuacji w centralnych i południowych rejonach Wielkiego Księstwa: „słomy y siana dostac nie można z racyi, że w przeszłym roku szarańcza trawę powyiadała, dla ktorey karystyi bydło y konie odchodzą" ${ }^{31}$. Michał K. Radziwiłł pisał 25 sierpnia 1748 r. z żalem i rezygnacją: „odbieram z Nieświeża z Mira i Korelicz, że szarańcza wielko [!] mnie szkodę zrobiła tak [się] Panu Bogu podobało"232.

Będącą ósmą z dziesięciu plag biblijnych inwazję szarańczy traktowano jako wyraz uzasadnionego gniewu Bożego. Sposób postrzegania klęski przez przedstawiciela magnaterii odzwierciedla konstatacja Hieronima F. Radziwiłła, wyrażona we wrześniu 1749 r.: „znaczno Boski Majestat słusznie zagniewany za zbrodnie nasze, za które gdyby Bóg był tak niechcący śmierci grzesznika, jak jest, słaba by dużo nadzieja w przebłaganiu on [!] była" ${ }^{233}$. W zdaniu zawarł akceptację kary boskiej, ale nie powstrzymał się od uwagi, że gdyby Stwórca faktycznie chciał wymierzyć sprawiedliwość, plaga byłaby znacznie większa.

Omawiane źródła zawierają relacje o elektrometeorach. Należą do nich wyładowania atmosferyczne (elektryczne), burze, którym towarzyszą pioruny powstające w chmurze typu Cumulonimbus, a także tworzące się między chmurami bądź pomiędzy chmurą a ziemią, dostrzegalne jako błyskawice ze zjawiskiem akustycznym (grzmotem). Charakterystyczny odgłos słyszany wraz z pojawieniem się błyskawicy jest konsekwencją wysokiej temperatury powodującej bardzo szybkie rozszerzenie się powietrza na długości kanału błyskawicy. Do grupy atmosferycznych zjawisk elektrycznych należy również zorza polarna.

Wyładowania elektryczne nazywano „burzą"234, „nawalnicą” i „szturmem” (rozumianym zarówno jako burza na lądzie, jak też na rzece) ${ }^{235}$. Pozostałe desygnaty stanowiące nazwy zjawisk związanych z burzą to oprócz używanych współcześnie („błyskawice”, „pioruny”, „grzmoty”) również „błyskanie”, „łyskawica”.

Nie zachowało się wiele opisów wyładowań atmosferycznych z terenów litewskich $\mathrm{z}$ interesującej nas epoki (znacznie więcej zebrałem relacji z Korony). $\mathrm{W}$ przebadanych materiałach najwięcej jest wzmianek o tym, że w jakimś określonym miejscu występowały burza, pioruny i grzmoty ${ }^{236}$. Osobną grupę stanowią

${ }^{231}$ Z Wilna d. 19. April., „Kuryer Polski” 1749, nr 649; Z Wilna d. 7. Jun., „Kuryer Polski” 1749, nr 665 .

${ }^{232}$ AGAD, AR, dz. VI, sygn. II-80a, s. 1600.

${ }^{233}$ Ibidem, sygn. II-81, k. 90v.

${ }^{234}$ Ibidem, sygn. II-80a, s. 40 (24 VII 1720, Mir); Z Wilna dnia 31. Lipca, „Kurier Litewski” 1762, nr 31, Supplement do gazet wileńskich.

${ }^{235}$ BPAN-PAUKr, sygn. 977, k. 253v (3 VII 1712); Z Grodna d. 6. Sept., „,Kuryer Polski” 1752, nr 834; S. Niezabitowski, op. cit., s. 213 (11 XI 1698, burza na Niemnie p. Sielcem).

${ }^{236}$ BPAN-PAUKr, sygn. 977, k. 109 (5 IV 1701, Mir), k. 153v (11 IV 1704, Świrżno k. Mira); Z Biáłey Ruśi d. 1. May, „Kuryer Polski” 1731, nr 73, s. 314; AGAD, AR, dz. VI, sygn. II-80a, s. 1960 
doniesienia o zgonach ludzi na skutek uderzenia pioruna, a także zabicia zwierząt $\mathrm{w}$ ten sam sposób ${ }^{237}$. Niekiedy pisano o szkodach i pożarach wyrządzonych przez wyładowania atmosferyczne ${ }^{238}$. Najdokładniejszą charakterystykę zjawisk burzowych stanowią opisy wyładowań elektrycznych nad kościołami bądź cerkwiami, które to budynki ze zrozumiałych względów były najbardziej narażone na wszelkie uszkodzenia spowodowane atmosferycznymi zjawiskami elektrycznymi z powodu wypiętrzonych elementów architektonicznych (wieże, krzyże, kopuły, dzwonnice) ${ }^{239}$.

Zwracają uwagę opisy burz nad miastami litewskimi, drukowane w „Kuryerze Polskim". Najobszerniejsza relacja dotyczy wyładowań atmosferycznych i szkód, które spowodowała „nawalnica” w Grodnie 2 września 1752 r. Najbardziej ucierpiał jeden z największych barokowych kościołów w Rzeczypospolitej, kościół oo. Jezuitów pw. św. Franciszka Ksawerego. Straty były tym dotkliwsze, że dopiero co zakończono przebudowę i remont świątyni (rusztowania nie zostały jeszcze zabrane). Burza trwała zaledwie godzinę (od godz. 21 do 22 wieczorem). Wicher przewrócił rusztowania i latarnię, a kosztowny krzyż umieszczony nad latarnią złamał się i upadł na dach. Pozrywane zostały dachy nad kaplicami i zakrystią, a kopuły wieńczące kaplice poodzierało z blachy. Wszystkie kościelne okna zostały potłuczone. Burza spowodowała szkody w zabudowaniach miejskich, a także w okolicznych wsiach, gdzie pioruny, które „gęstookolicznie padały”, popaliły różne budynki. Ludzie - jak donosiła gazeta - byli zmuszeni do ucieczki ze swoich domów, „boiąc się zawalenia”240. Trzy lata później, 10 czerwca 1755 r. piorun uderzył w kościół oo. Kamedułów w Pożajściu, spaliły się dach kryty miedzią i biblioteka. Sam kościół łącznie z krużgankiem, archiwum i największym dzwonem nie uległy zniszczeniu ${ }^{241}$. Chwile strachu przeżyli parafianie zgromadzeni na rannej mszy św. w kościele pw. Wszystkich Świętych w Wilnie 6 czerwca 1756 r. O godz. 6 rano w kościół uderzył piorun, niszcząc dużą część muru, spustoszenie i trwoga były na tyle duże, że ksiądz, który wyszedł już, by celebrować nabożeństwo, wrócił do zakrystii ${ }^{242}$.

(26 V 1754, Nieśwież), s. 1380 (15 VIII 1745, Biała k. Nieświeża), s. 1918 (6 VII 1753, ŚwierżnoNieśwież), s. 2000 (6 IV 1755, Kamień, województwo mińskie), s. 2005 (13 V 1755, Korelicze), s. 2007 (8 VI 1755, Nieśwież), s. 2052 (10 VI 1756), s. 2036 (30 V 1757, Biała k. Nieświeża), s. 2104 (23 VII 1757, Mikołajewo n. Niemnem), s. 2106 (11 VIII 1757, Nieśwież), s. 2226 (9 IV 1759); S. Niezabitowski, op. cit., s. 148 (21 IV 1697, Nieśwież-Malew).

237 S. Niezabitowski, op. cit., s. 196 (13 VI 1698, Sobotniki); Abrys..., s. 40 (po 29 VI 1705); AGAD, AR, dz. VI, sygn. II-80a, s. 831 (24 V 1737, Korelicze), s. 1054 (11 V 1740, Mir), s. 2007 (19 VIII 1757, Połonne); M. Matuszewicz, op. cit., t. 2, s. 309 (przed 24 VI 1763, Brześć).

${ }^{238}$ BTNP, sygn. 113, k. 101 (23 V 1715, Wydybor, Widibor).

239 Витебская летопис..., s. 222 (15 VI 1697, Wieliż, 20 VIII 1697, Smoleńsk, [b.d.m.] 1698, Witebsk), s. 224-225 (7 IV 1701), s. 226 (18 X 1704).

${ }^{240}$ Z Grodna d. 6. Sept., „Kuryer Polski” 1752, nr 834.

${ }^{241}$ Z Kowna dnia 17 Czerwca, „Kuryer Polski” 1755, nr 101.

${ }^{242}$ Z Wilna d. 7. Junii, „Kuryer Polski” 1756, nr 152. 
Zainteresowanie budzi incydent przytoczony przez Stanisława Niezabitowskiego o uderzeniu pioruna w siedzącego na polu pod gruszą Stanisława Mentyckiego w Kosiczach (nad rzeką Jatrą w powiecie nowogródzkim) 16 maja 1699 r. Zginął pies znajdujący się obok, a grusza połamała się. Sam Mentycki uszedł z tego wypadku cało i zdrowo, choć jego ubranie (czapka, suknie i kaftan) zostały podarte $\mathrm{w}$ strzępy. Niezabitowski nadmienił, że na ciele cudem ocalałego piorun „blizny wielkie i znaki uczynił”243. Blizny wspomniane w relacji to zapewne "figury Lichtenberga" (Lichtenberg-Figuren) powstające w wyniku oddziaływania elektronów pod silnym napięciem. Opis zniszczonego ubrania także jest typowy dla podobnych sytuacji, wiąże się z gwałtowną przemianą potu w parę $e^{244}$.

W pamiętniku Franciszka Szyrmy z powiatu pińskiego zjawiska powstałe wskutek wyładowań atmosferycznych (pioruny, grzmoty, błyskawice) odczytywane były jako niepokojący prognostyk. Autor w pojawieniu się ich widział „znak gniewu bożego". Pamiętnikarz zwracał uwagę na porę roku, miesiąc, a nawet porę dnia występowania wyładowań atmosferycznych, próbując na podstawie tego przeprowadzać interpretację ich znaczenia dla przyszłych wydarzeń ${ }^{245}$. W kwestii burzowych efektów akustycznych starano się również dokonać swoistej systematyzacji grzmotów, pozwalającej określić ich konsekwencje, odwołując się do astrologii. Tak więc zespół skutków wynikających $\mathrm{z}$ odgłosu wyładowań określano $\mathrm{np}$. za pomocą obecności Słońca w konkretnym znaku zodiaku bądź słyszenia grzmotu w danym miesiącu. Niewątpliwie w różnych rejonach kraju sposób prognozowania skutków grzmotu był różny. Za nietypowe pory słyszenia grzmotów uchodziły zima, jesień, wczesna wiosna, co widać również w pamiętniku Szyrmy ${ }^{246}$.

${ }^{243}$ S. Niezabitowski, op. cit., s. 234.

${ }^{244}$ Więcej na ten temat zob. R. Cerveny, Wielkie katastrofy i anomalie klimatyczne $w$ dziejach, przeł. I. Stąpor, Warszawa 2008, s. 54, 61-62.

${ }^{245}$ BTNP, rkps 113, k. 90v (17 IV 1706), k. 100v (I i 16 II 1715), k. 103v (31 III 1717), k. 117v (11 II 1731).

${ }^{246}$ Zwraca uwagę interesujące źródło Miscellanea. Mowy, listy, wiersze, i wiele pism do dzieiów Polskich należących (AGAD, AR, dz. II, sygn. 12), w którym odnajdujemy szereg przykładów rozmaitych konsekwencji grzmotu słyszanego podczas różnych okresów w ciągu roku. Na podstawie wspomnianego materiału można przedstawić następujące zestawienie: Słońce w znaku Skorpiona - dobry urodzaj, ale jednocześnie kłopoty z powodu niskich cen żyta; Słońce w znaku Byka - urodzajny rok w górach, ale zły na terenach nizinnych, jednocześnie dobry rozwój gatunków zwierząt leśnych; Słońce w znaku Bliźniąt - częste deszcze i opady gradu, urodzaj na jarzyny, mało ptaków oraz gadów i płazów; Słońce w znaku Raka - klęska głodu, wyniszczenie populacji ludzkiej (może również z powodu wojny?), plaga szarańczy bądź plaga „robactwa” niszczącego „owoce i ziemię”; Słońce w znaku Lwa - na początku roku kłopoty państw, wysokie ceny zboża, na końcu roku pomory wśród ludzi; Słońce w znaku Panny - „zdradziectwa między ludźmi”, pomór bydła; Słońce w znaku Skorpiona - wysoka umieralność kobiet („odchodzenie białych głów”), poronienia, wielkie wiatry, „skąpość” bydła rogatego; Słońce w znaku Strzelca - deszcze, wczesny opad owoców z drzew, waśnie między dworzanami królewskimi; Słońce w znaku Wagi - na początku roku susza, na końcu roku pluchy („pluta”), wysokie ceny żywności; Słońce w znaku Koziorożca - migracje ludzkie („rozproszenie narodów wiele”), epidemia dżumy; 
Wśród zebranych źródeł znalazłem również opisy zórz polarnych (Aurora borealis), efektu oddziaływania naładowanych elektrycznie cząsteczek materii, które wyrzucone z powierzchni Słońca, docierają do górnych warstw atmosfery ziemskiej (mezosfera, jonosfera), gdzie wchodzą $\mathrm{w}$ reakcje $\mathrm{z}$ rozrzedzonymi gazami. Zorze polarne powstają od 60 do $1000 \mathrm{~km}$ nad ziemią. Przybierają rozmaite kształty: jednostajne łuki, wstęgi, draperie, migocące zjawiska, czerwone łuki i plamy, wysokie promienie ${ }^{247}$. Ich barwy są związane ze składem atmosfery ziemskiej. W odległości 90-100 km od ziemi powstają zorze o zabarwieniu czerwonym, na wysokości poniżej $120 \mathrm{~km}$ - fioletowe i niebieskawe, natomiast od 120 do $180 \mathrm{~km}$ od ziemi - zielone. Przyczyną koloru kojarzonego z krwią i ogniem są bardzo silne chmury wiatru słonecznego. Wpływ na barwę purpurową i ciemnoczerwoną mają atomy azotu, przyczyną kolorów czerwonego i zielonego jest świecenie tlenu. Kolor żółty powstaje w rezultacie mieszania się barw czerwonej i zielonejej ${ }^{248}$.

$\mathrm{W}$ omawianej epoce pojawiały się próby racjonalnego opisania zórz polarnych, ale nie wykształciło się jednolite nazewnictwo mogące sprzyjać precyzyjnej identyfikacji zjawiska. Gabriel Rzączyński (1745) podał kilka jego nazw: Aurora Borea seu Lumen Boreale, Lumen Septentrionale Crepusculum Boreum, Nord-Licht, „Światło północne”, Borealem Caeli ${ }^{249}$. Stanisław Duńczewski (1748) nazwał zorzę Aurora Septemtrionalis, przy czym zauważył, że na ziemiach polsko-litewskich zjawisko typowe dla krajów północnych jest widywane najczęściej zimą, wyjątkowo jesienią i rzadko wiosną ${ }^{250}$. Wbrew temu stwierdzeniu zjawisko może być obserwowane we wszystkich porach roku. Gazety drukowane na początku lat 60 . XVIII w. nazywały je „zorzą północną”251.

W materiale źródłowym odnajdujemy dwie tendencje redagowania opisów zórz polarnych. Pierwsza traktuje je jako nadprzyrodzoną wieszczbę nieszczęść,

Słońce w znaku Wodnika - wielkie deszcze, trwoga spowodowana silnymi wiatrami, „dychawice i świerzby”, „poruszenie wielkie na świecie”; Słońce w znaku Ryb - susza, mrozy, „obfitość wina"; bogactwo, choroby ludzi. Zwraca również uwagę zestawienie potencjalnych konsekwencji zjawisk akustycznych (grzmotów) występujących w poszczególnych miesiącach: styczeń - gwałtowne wiatry, urodzaj na zboże; luty - wysoka umieralność ludzi głównie bogatych; marzec gwałtowne wiatry, urodzaj na zboże, „zdrady” między ludźmi; kwiecień - „dobry i urodzajny rok"; maj - klęska głodu; czerwiec - urodzaj, choroby; lipiec - urodzaj na zboże, złe zbiory owoców w sadach; sierpień - pomyślność Rzeczypospolitej, choroby ludzi; wrzesień - urodzaj na zboże, „mężobójstwo potentatów”; październik - gwałtowny wiatr, nieurodzaj zboża i „owoców drzewianych”; listopad - urodzaj na zboże, „wdzięczność w onem roku”; grudzień - urodzaj na zboże, pokój i zgoda między ludźmi. Ibidem, s. 799-800

${ }^{247}$ J. Mergentaler, Słońce - Ziemia, Warszawa 1994, s. 171-172.

${ }^{248}$ M. Szymocha, Kiedy niebo zapłonie, „Wiedza i Życie” 2005, nr 7, s. 67.

${ }^{249}$ G. Rzączyński, Auctuarium..., s. 475-476.

${ }^{250}$ S. Duńczewski, Relacya II O Meteorach, álbo Powietrznych apparycyach dźiwnych y osobliwszych $w$ Polszcze y W.X.L. etc., w: Raritates Polskie W.X. Litewskiego y prowincyi do nichze należacych, Kalendarz 1749, Zamość 1748, s. M.

${ }^{251}$ O Zorzy Pułnocney [!], „Kurier Litewski” 1762, nr 52, Wiadomości literackie. 
gdy zorze nazywano „kometami”. Cechą charakterystyczną tych materiałów były fantasmagoryczne opisy spektakli rozgrywających się na niebie. W drugim rodzaju tekstów zorze zostały przedstawione jako zjawisko naturalne bez złowieszczych implikacji.

W widoku zórz dopatrywano się podniebnych bitew ${ }^{252}$, „ognistych smoków” lub obiektów architektonicznych (wieże, baszty itp. ${ }^{253}$. Problem nietypowych relacji we współczesnej historiografii polskiej nie był głębiej analizowany, uważa się, że miały one związek z przywidzeniami, zbiorowymi halucynacjami bądź też traktuje się je jako czołowy przykład sarmackich konfabulacji i fantazjowania. Zwracano uwagę na przyczynę konstruowania opisów rzekomych zjawisk, co „wiązało się przeważnie z powstawaniem silnych zbiorowych emocji, napięć czy nawet psychoz społecznych" ${ }^{254}$. Takie wyjaśnienie wydaje się dość powierzchowne, ponieważ ignoruje wiele istotnych czynników związanych $\mathrm{z}$ redagowaniem relacji. Przyczyną wielu halucynacji wzrokowych i złudzeń optycznych w omawianej epoce mogły być zatrucia pożywieniem bądź rozmaite patologie natury psychicznej ${ }^{255}$. Jednak przechowane do naszych czasów opisy nie zawsze stanowią przykład odnotowanych faktów omamów. Specyfika tekstów rodzi przypuszczenie, iż $\mathrm{w}$ wielu przypadkach opisy zórz były konsekwencją językowej reakcji autorów, wynikającej z podobieństwa niezwykłych kształtów zjawiska do rozmaitych desygnatów (stąd opisy mitycznych zwierząt, budowli, oręża, a nawet postaci) ${ }^{256}$. Posługiwano się terminologią wykorzystywaną w czynnościach dnia codziennego albo określającą zwykłe i znane zachowania społeczne bądź narzędzia powszechnego użytku (np. gospodarcze), czy też obiekty architektoniczne w zależności od skojarzeń. Prawidłowość ta w odniesieniu do zjawisk atmosferycznych jest znana w badaniach dialektologicznych. Władysław Kupiszewski przypomniał, że

252 S.I. Isajew, N.W. Puszkow, Zorze polarne, przeł. M. Kozłowski, Warszawa 1961, s. 9.

${ }^{253}$ Por.: J.M. Briggs, Aurora and Enlightenment. Eighteenth-century explanations of the Aurora borealis, „Isis” 1967, t. 58, s. 491-503; P. Fara, Lord Derwentwater's Lights. Prediction and the Aurora Polaris, „Journal for the History of Astronomy”, VIII 1996, t. 27, nr 3, s. 239-258. Kazimierz Maliszewski w swojej pracy zacytował fragment listu Jakuba Kazimierza Rubinkowskiego do Elżbiety Sieniawskiej, w którym donosił on o pojawieniu się 1 marca 1721 r. nad Toruniem dziwnego zjawiska, najpierw „wielkiej jasności”, a później tajemniczych „chmur”, następnie widziane były „wieże, baszty, armatury” itp., a nawet różne mityczne stworzenia. K. Maliszewski uznał ten opis za przykład konfabulacji (K. Maliszewski, $W$ kręgu staropolskich wyobrażeń..., s. 268-269). Jednak relacja z całą pewnością zawiera doniesienie o obserwacji zorzy polarnej, która w tym czasie była widziana w różnych rejonach Korony i Litwy, co potwierdzają Gabriel Rzączyński i Stanisław Duńczewski (por.: G. Rzączyński, Auctuarium..., s. 477; S. Duńczewski, Relacya II..., s. M).

${ }^{254}$ K. Maliszewski, $W$ kręgu staropolskich wyobrażeń..., s. 265.

${ }^{255}$ Z. Kuchowicz, Z badań nad stanem biologicznym społeczeństwa polskiego od schyłku XVI do końca XVIII wieku, Łódź 1972, s. 45.

${ }^{256}$ Opis zorzy polarnej podróżnika Mariusza Zaruskiego zob. E. Stenz, Zorze polarne, „Przyroda i Technika", V 1929, z. 5, s. 206. 
chmury jeszcze w XX w. w gwarach występujących na ziemiach polskich określano np. nazwą wędrownych dziadów lub nazwami pochodzącymi od kłębka włókna lnianego (pacześnina, pacześne) w nawiązaniu do zmierzwionego (wełnistego) kształtu chmur rodzaju Cumulus ${ }^{257}$.

Nie można pominąć ogromnego znaczenia, które przypadło w udziale propagandowemu oraz moralizatorskiemu wydźwiękowi tekstów, co konweniowało $\mathrm{z}$ bieżącymi wydarzeniami społecznymi i politycznymi ${ }^{258}$. Człowiek doświadczony przez kataklizmy wojenne przyjmował za oczywiste tłumaczenie niecodziennych naturalnych zjawisk retoryką hermeneutyki biblijnej i stylistyką proroctw ${ }^{259}$, natomiast w czasie pokoju sytuacja na niebie, powstająca w takich samych warunkach fizycznych, była odbierana jako osobliwość przyrodnicza bez konotacji nadprzyrodzonych ${ }^{260}$. W zależności od licznych uwarunkowań wykorzystywano odmienną semiotykę, w inny też sposób przeprowadzano konceptualizację świata.

Stosowanie do zórz polarnych nazwy „kometa” często wprowadzało w błąd badaczy cytujących bez komentarza staropolskie opisy „komet”, które w rzeczywistości były relacjami z obserwacji zórz polarnych bądź innych zjawisk niebieskich $^{261}$. Maniera narracyjna, powszechna w omawianej epoce, stanowiła niewątpliwie rezultat braku wiedzy, ale też bezrefleksyjnego czerpania informacji z przestarzałych dzieł autorów starożytnych ${ }^{262}$, bądź też była efektem rozmyślnego

${ }^{257}$ W. Kupiszewski, op. cit., s. 19, 21.

258 Tendencja manipulowania informacjami dotyczącymi zjawisk przyrodniczych jest widoczna w najstarszych źródłach chrześcijańskich podczas dyskursu teologicznego i historiozoficznego. Zob. P. Janiszewski, Żywioły w stużbie propagandy, czyli po czyjej stronie stoi Bóg. Studium klęsk i rzadkich fenomenów przyrodniczych u historyków Kościoła IV i V wieku, w: Chrześcijaństwo u schyłku starożytności. Studia źródłoznawcze, t. 3, red. T. Derda, E. Wipszycka, Kraków 2000, s. 57.

${ }^{259}$ P. Kowalski, Powódź. Żywioły w Andrzeja Komonieckiego Chronografii, albo Dziejopisie żywieckim, w: Pejzaże kultury. Prace ofiarowane Profesorowi Jackowi Kolbuszewskiemu w 65. rocznice Jego urodzin, red. W. Dynak, M. Ursel, Wrocław 2005, s. 85.

${ }^{260}$ Egzemplifikacją dla powyższych uwag są opisy zorzy polarnej przytoczone w obliczu licznych katastrof związanych z wielką wojną północną, pióra unickiego zakonnika o. Jana Oleszewskiego $(1704,1721)$. Zjawisko to zostało przedstawione jako praesagium, znak przyszłych nieszczęść. W oczach Stanisława Duńczewskiego zorza polarna to niezwykłe naturalne zjawisko oglądane „Z wielkim podźiwieniem [!]” (S. Duńczewski, Relacya II..., s. M). Niczego oprócz fascynujących wrażeń wizualnych nie widzieli też w zorzy polarnej redaktorzy „Kuryera Polskiego” i „Kuriera Litewskiego” $\mathrm{z}$ lat 1762-1763. W notatkach w wymienionych czasopismach odnajdujemy też doniesienia o naukowych staraniach zmierzających do wyjaśnienia natury fenomenu.

${ }^{261}$ Tendencja taka jest widoczna w pracach: W. Smoleński, Wiara $w$ życiu społeczeństwa polskiego $w$ epoce jezuickiej. Studyum historyczne, w: Ognisko. Książka zbiorowa wydana dla uczczenia 25 letniej pracy T.T. Jeża, Warszawa 1882, s. 232; K. Maliszewski, $W$ kregu staropolskich wyobrażeń..., s. 268-269; E. Kaczyńska, Wizerunek własny człowieka polskiego baroku (Pamiętniki Krzysztofa Zawiszy), „Litteraria” 2012, t. 39, s. 53.

${ }^{262}$ Na temat kondycji polskiej astronomii w dobie saskiej zob. T. Przypkowski, Czasy saskie, w: Historia astronomii w Polsce, t. 1, red. E. Rybka, Wrocław-Warszawa-Kraków-Gdańsk 1975, s. 305-306. 
posługiwania się toposem złowrogiego prognostyku, za jaki uchodziło pojawienie się komety ${ }^{263}$. Wyobrażenia potoczne rozszerzały znaczenie tych obiektów na wszelkie niecodzienne zjawiska obserwowane na nieboskłonie, a w sytuacji, gdy dodatkowo towarzyszyły tym wizjom barwy kojarzone $\mathrm{z}$ krwią i pożogą ${ }^{264}$, wyobraźnia formowała konglomerat różnorodnych sugestywnych archetypicznych pojęć służących interpretacji spostrzeżeń niebieskich w duchu apokaliptycznym ${ }^{265}$. Interesujące wyjaśnienie wiązania zórz polarnych z kometami odnajdujemy w „Kuryerze Warszawskim” z marca 1761 r., w którym zjawisko zostało nazwane „zorzą północną”: „co do kształtu bardzo podobna była do miotły, która z kometami pokazywać się zwykła"266. Wprowadzającą w błąd nomenklaturę można traktować jako konsekwencję podobieństwa kształtów, ale również powszechnego

${ }^{263} \mathrm{~W}$ kulturze ludowej pojawienie się komety odczytywano jako zapowiedź wojny, nieszczęścia, zarazy, suszy, nieurodzaju, głodu, nędzy, chorób, pomoru ludzi i bydła. Słownik stereotypów..., cz. 1: Niebo, światła niebieskie, ogień, kamienie, Lublin 1996, s. 237.

${ }^{264}$ Por. Wyjątki ze źródeł historycznych o nadzwyczajnych zjawiskach hydrologiczno-meteorologicznych na ziemiach polskich w wiekach od X do XVI, wybór, przeł. R. Girguś, W. Strupczewski, red. A. Rojecki, Warszawa 1965, poz. 8, s. 18-19; M.H. Malewicz, op. cit., s. 103-104 (aneks II).

265 Określeniem „kometa” w omawianej epoce obejmowano w zasadzie wszystkie niezwykłe zjawiska na niebie. W ich opisywaniu dostrzegamy synkretyzm stanowiący wynik niewiedzy i jednoczesnej potrzeby uporządkowania i scharakteryzowania zjawisk. Przykładem niejednoznacznych eksplikacji są prace Stanisława Duńczewskiego, którego nie dziwiły zorze polarne i potrafił odróżnić je od zjawisk astronomicznych, a jednak w swojej rozprawie na temat komety z $1744 \mathrm{r}$. przywołał typologię tych obiektów, autorstwa Pliniusza Starszego (I w. n.e.), który wymienił aż 12 zjawisk określanych nazwą „komety”. W wykazie bez trudności można odnaleźć różne nietypowe sytuacje na niebie, które kometami nie były (np. fotometeory, elektrometeory i in.). W swojej pracy z 1744 r. Duńczewski podzielił komety na dwa rodzaje: „Komety, a raczey Ogniste Meteora y Phaenomena”. Ich wygląd charakteryzował w następujący sposób: „ktore się na Powietrzu rodzą z Exhalacyi tłustych, siarczystych, kleykich, żywicznych, saletrzystych \& c. y zapalaią się, albo od Sfery Ognia Elementarnego nad powietrzem, albo od ustawiczney agitacyi y Słonecznego upału, biegnąc co dzieńnie w koło świata ad raptum primi mobiles razem z Atmosferą. [...] poty na Powietrzu świecą, poki im alimentu do palenia staie”. Drugi rodzaj komet według Duńczewskiego to po prostu „komety”, które zdefiniował tak: „Gwiazdy taiące się w wysokości Nieba y w niezmierney miąszośći Obłokow”. (S. Duńczewski, Ciekawosc o komecie Roku Panskiego MDCCXLIV dalsza swiatła obrotu y procedencyi iego koniektura, az do skonczenia apparicyi na horizoncie zamoyskim, Zamość 1744 , s. [a]). Powyższe cytaty wskazują na to, że autor za pierwszy rodzaj „komet” uważał zjawisko zórz polarnych, o czym świadczy zbieżność definicji obu zjawisk (komet i zórz) w jego pracach. O zorzach polarnych mianowicie napisał w 1748 r.: „bardzo często wynikaią z exchalacyi siárczystych y inszych ktore są materyą piorunową". W przytoczonym druku nie nazwał jednak zórz „kometami”, lecz użył terminu Aurora Septemtrionalis (S. Duńczewski, Relacya II..., s. M). Definiowanie i opisywanie niecodziennych zjawisk sprawiało ogromne problemy interpretacyjne. Dostrzegalne są: chaos w formach eksplikacji, niekonsekwencja i amplifikacja. Dziwi fakt, że Duńczewski w kometach widział złowrogą przesłankę, natomiast w przypadku obserwacji zórz polarnych podkreślał jedynie ich widowiskowość, nie traktując jako praesagium, prodigium czy mirabilis; jednocześnie do obu zjawisk stosował tę samą nomenklaturę.

${ }^{266}$ Z Wiednia dnia 4 marca, „Kuryer Warszawski” 1761, nr 11, Supplement. 
uznawania zależności między charakterem obu zjawisk. Wielki dykcyonarz ogłoszony drukiem w 1779 r., podając znaczenie słowa "kometa” (funkcjonujące wówczas $\mathrm{w}$ rodzaju męskim i żeńskim), odnotował, że jest to „miotła na niebie”267.

Istnieje możliwość weryfikacji budzących uzasadnione zastrzeżenia opisów zjawisk w oparciu o źródła z epoki. Przypadki niektórych relacji są jednak trudne do sprawdzenia $\mathrm{z}$ powodu niemożności skonfrontowania ich $\mathrm{z}$ dodatkowym źródłem. Znalazłem także wzmianki na tyle niejasne, że trudno stwierdzić, co opisują zjawisko atmosferyczne czy astronomiczne. Trzeba mieć też na uwadze, że wiele nieprawdopodobnych opisów było płodami wybujałej wyobraźni, jak uznał analizujący XVII-wieczne prognostyki Jerzy Kroczak. Znajdowały one zastosowanie w zależności od zadań i celów ogłaszanych drukiem traktatów astrologicznych, charakteru zamówienia lub zapotrzebowania ${ }^{268}$.

Przykładem doszukiwania się w zorzy złych przepowiedni są opisy Krzysztofa Zawiszy. Pozostawił on wspomnienie obserwacji zjawisk zorzy i słońc pobocznych mających miejsce w $1721 \mathrm{r}$. Jak już wcześniej pisałem, wszystkie nazwał ogólnie „kometami” ${ }^{269} . \mathrm{Z}$ opisu wynika, że pierwszym zjawiskiem były schodzące się ze sobą na niebie dwie „kolumny” powodujące wielką jasność i zarazem huk „niby strzelania”. Zjawisko miało miejsce nieznanej marcowej nocy i trwało godzinę. W kolejnej relacji donosił, że w innych miejscach widziano jeszcze dodatkowo trzecią „kolumnę”, „rozpędzającą” poprzednie.

Źródła potwierdzają, że zorzę w 1721 r. obserwowano m.in. w Gdańsku i Toruniu ${ }^{270}$. $Z$ tego samego roku pochodzi opis odnotowany przez bazylianina o. Oleszewskiego, który nazwał zjawisko „kometą” w rodzaju męskim. W jego relacji, podobnie jak u Zawiszy, pojawiła się wizja „słupów” obijających się o siebie, miało ich być aż „czterdzieści” i każdy był innego koloru ${ }^{271}$. Ruch zjawiska zobrazowany opisem „słupów” oddalających, przybliżających i „przewracających się" został przytoczony także w relacji z Grodna z 10 października $1731 \mathrm{r}^{272}$ $\mathrm{W}$ tym doniesieniu, podobnie jak $\mathrm{w}$ opisie Zawiszy, jest mowa o odczuwanych wrażeniach akustycznych towarzyszących obserwacjom. Na temat dźwięków zórz pisał w popularnym druku Stanisław Duńczewski $(1748)^{273}$. Zagadnienie tych odgłosów nie zostało do tej pory naukowo wyjaśnione; wiadomo, że nie wszystkim zjawiskom zórz one towarzyszą ${ }^{274}$. Ich przyczynę stanowią

\footnotetext{
${ }^{267}$ M.A. Troc, op. cit., s. 617.

${ }^{268}$ J. Kroczak, „Jeśli mię wieźdźba prawdziwa uwodzi...” Prognostyki i znaki cudowne w polskiej literaturze barokowej, Wrocław 2006, s. 131.

269 Pamiętniki Krzysztofa Zawiszy..., s. 358.

${ }^{270}$ G. Rzączyński, Auctuarium..., s. 477.

${ }^{271}$ Abrys..., s. 104.

${ }^{272}$ Z Grodna d. 10. Oct., „Kuryer Polski” 1731, nr 95, s. 408.

${ }^{273}$ S. Duńczewski, Relacya II..., s. M.

274 J. Mergentaler, op. cit., s. 174.
} 
prawdopodobnie zjawiska elektryczne lub magnetyczne występujące kilkadziesiąt metrów nad ziemią ${ }^{275}$.

Charakterystyczne w źródłach są opisy barw przywodzące na myśl jedne z najstraszniejszych katastrof, których może doświadczyć i jakie wyobrazić sobie człowiek. Autor relacji z Grodna pisał, że „słupy krwawo ogniste pokazały się"276. Podobnie o. Oleszewski zauważył, że pod koniec obserwacji zorzy w 1704 r. pojawił się „obłok na kształt słupa goreiący”277. Zorza nazwana została przez niego "kometą" (rodzaj męski) zwiastującym klęskę wojsk litewsko-moskiewskich ze Szwedami pod Sledziową Słobodką, a zjawisku towarzyszył nieustanny ruch zmieniających się elementów wizualnych „strasznie prędkim impetem”. Na początku pojawił się „kulisty obłok”, później „ognisty promień”, następnie „obłok”, „gorejący miecz" i "słup gorejący”. Stałym składnikiem omawianych opisów był motyw ognia. Autor relacji o zorzy grodzieńskiej stwierdził, że „Niebo drzeć poczęło w ogniu”, a piszący o zorzy $1721 \mathrm{r}$. Oleszewski powiedział: „ognie tedy szerzyły się ku wschodowi".

Donoszono również o czasie trwania zjawiska. W relacji Oleszewskiego zorza z 1704 r. była do „samego północka”, opisane przez niego zjawisko z 1721 r. zaczęło się przed północą, a trwało do godz. 3. Zorzę polarną nad Grodnem w $1731 \mathrm{r}$. widziano w dwóch następujących po sobie nocach, zapewne 8/9 i 9/10 października, a trwała prawdopodobnie za każdym razem „do samego niemal świtania”.

Relacje o zorzach polarnych znajdujemy także w gazetach na początku lat 60 ., jednak charakter opisów zjawiska znacznie odbiegał od przytoczonych powyżej. Widowiskowej sytuacji na niebie nie rozpatrywano w tych publikacjach w kategoriach nadprzyrodzonych, co stanowiło zapewne efekt oddziaływania zachodnioeuropejskich prądów oświeceniowych. W Wilnie zorza polarna była oglądana pod koniec 1762 r.: 18 grudnia od ok. godz. 21 do ok. północy i 21 grudnia. W Akademii Wileńskiej odbyła się w lipcu 1762 r. dysputa na temat sposobów obserwowania zjawiska ${ }^{278}$. W „Kurierze Litewskim” ogłoszono drukiem zawiadomienie adresowane głównie do zajmujących się naukami ścisłymi o wykonywanie szczegółowych pomiarów obserwacji i przesyłania swoich ustaleń Akademii Wileńskiej ${ }^{279}$. Relacje z gazet drukowanych mogą wskazywać na to, że początek lat 60. XVIII w. był okresem wzmożonej aktywności Słońca. Zorza polarna została dostrzeżona również $\mathrm{w}$ Wiedniu 3 marca $1761 \mathrm{r}$. i opisana przez profesora tamtejszego uniwersytetu - o. Maksymiliana Hella SJ ${ }^{280}$. Z tego okresu (26 II 1761 r.) zachowała się lapidarna relacja Michała K. Radziwiłła obserwującego nocne niebo

\footnotetext{
${ }^{275}$ M. Szymocha, op. cit., s. 67.

${ }^{276}$ Z Grodna d. 10. Oct., „,Kuryer Polski” 1731, nr 95, s. 408.

277 Abrys..., s. 32.

278 O Zorzy Putnocney [!], „Kurier Litewski” 1762, nr 52, Wiadomości literackie.

${ }^{279}$ Ibidem.

${ }^{280}$ Z Wiednia dnia 4 marca, „Kuryer Warszawski” 1761, nr 11, Supplement.
} 
nad Nieświeżem: „w nocy fenomen wielki, czerwone łuno na niebie było” ${ }^{281}$. Dwa lata później, 18 października 1763 r. spektakularne widowisko zorzy polarnej widziano nad Warszawą ${ }^{282}$.

Bezmiaru szkód w czasach upałów i suszy dopełniały pożary. Spośród klęsk żywiołowych były one najczęstszym i najczęściej opisywanym kataklizmem w omawianej epoce. Gwałtownemu rozprzestrzenianiu się konflagracji sprzyjały warunki pogodowe, ale również m.in. ciasna zabudowa w przypadku miast czy architektura drewniana na przedmieściach i wsiach ${ }^{283}$. W $1748 \mathrm{r}$. w czasie upału i suszy pożary wybuchły w Wilnie ${ }^{284}$, Brześciu ${ }^{285}$, Szkłowie ${ }^{286}$, Witebsku ${ }^{287}$. Ogromne straty poniosło Wilno, ale duża część miasta została spalona również następnego roku, także w okresie wysokich temperatur ${ }^{288}$. W 1748 r. w Brześciu spłonęło ponad 80 domów, a w Witebsku pożar strawił 168 domów.

Problematyka odnosząca się do niniejszego tematu jest bardzo rozległa i nie ma możliwości omówienia jej w wyczerpujący sposób w krótkim opracowaniu. Obok czynników przyrodniczych (np. susza, uderzenie pioruna) częstym powodem pożaru były działalność gospodarcza człowieka bądź też celowe zaprószanie ognia. W przeważającej ilości przypadków nie można stwierdzić przyczyny pojawienia się go.

W relacjach dotyczących pożarów uwagę zwracają opisy klęski zmniejszonej dzięki czynnikom przyrodniczym. Wielki pożar Wilna 11 czerwca 1748 r. został przytłumiony przez deszcz, który spadł wieczorem ${ }^{289}$. Podobnie podczas szalejącego ognia w Witebsku 2 sierpnia 1752 r. jego dalszym postępom przeszkodziły chmura deszczowa i wiatr, który zaczął wiać w przeciwną stronę, co uchroniło przed płomieniami Rynek ${ }^{290}$. Wiatr ocalił również Wilno przed rozprzestrzenieniem się ognia 27 września 1761 r. ${ }^{291}$ Zaś pożar, który wybuchł tu w nocy z 5 na 6 czerwca 1756 r., został ugaszony przez gwałtowny deszcz „z grzmotem y piorunami”292.

W omawianej epoce Wilno przeżyło trzy wielkie pożary, które pochłonęły całe miasto bądź większą jego część $(1737,1748,1749)^{293}$, ale oprócz tego miał tu

\footnotetext{
${ }^{281}$ AGAD, AR, dz. VI, sygn. II-80a, s. 2293.

${ }^{282}$ Z Warszawy dnia 19. Października, „Wiadomości Uprzywileiowane Warszawskie” 1763, nr 84, Supplement.

${ }^{283}$ Problematykę ustawodawstwa przeciwpożarowego omówił Maurycy Zajęcki (op. cit., s. 154-196).

${ }^{284} Z$ Wilna d. 15. Junij, „Kuryer Polski” 1748, nr 604.

${ }^{285}$ Z Brzescia Litewskiego d. 30. Julij, „Kuryer Polski” 1748, nr 611.

${ }^{286}$ Z Mohylowa d. 29. Junii, „Kuryer Polski” 1748, nr 608.

${ }^{287}$ Z Witebska d. 17. Julij, „Kuryer Polski” 1748, nr 611.

${ }^{288}$ Z Wilna d. 14. Junii, ,Kuryer Polski” 1749, nr 666.

${ }^{289}$ Z Wilna d. 15. Junij, „Kuryer Polski” 1748, nr 604.

${ }^{290}$ Z Witebska d. 6. Augusti, „Kuryer Polski” 1752, nr 831.

${ }^{291}$ Z Wilna d. 2 Pazdźiernika, „Kurier Litewski” 1761, nr 40.

${ }^{292}$ Z Wilna d. 7. Junii, „Kuryer Polski” 1756, nr 152.

${ }^{293}$ J.I. Kraszewski, Wilno od początków jego do roku 1750, t. 2, Wilno 1840, s. 177.
} 
miejsce szereg mniejszych lub większych konflagracji (zob. tabela 1). W sumie w tym czasie w Wilnie wybuchło 13 pożarów, podczas których ucierpiało więcej niż kilka kamienic. Po pożarze 8 czerwca 1749 r., w wypracowanie zasad bezpieczeństwa przeciwpożarowego osobiście zaangażował się wojewoda wileński i hetman wielki litewski Michał K. Radziwiłł, który 16 lipca odbył naradę z magistratem miejskim dotyczącą tej kwestii, a półtora tygodnia później, 25 lipca podpisał Postanowienie miasta do porzadków i bezpieczeństwa ognia ${ }^{294}$.

Tabela 1

Pożary w Wilnie w latach 1700-1756

\begin{tabular}{|c|c|c|}
\hline Data & Skutki/ lokalizacja & Źródło \\
\hline 18 III 1700 & zniszczona część miasta & J.I. Kraszewski, op. cit., s. 177 \\
\hline $18 \mathrm{~V} 1706$ & $\begin{array}{l}\text { zniszczone okolice Ratusza; zginęło } \\
\text { ok. } 50 \text { ludzi }\end{array}$ & $\begin{array}{l}\text { Витебская летопис.., s. 227; } \\
\text { J.I. Kraszewski, op. cit., s. } 177\end{array}$ \\
\hline $26 \mathrm{~V} 1715$ & zniszczone okolice Ostrej Bramy & J.I. Kraszewski, op. cit., s. 177 \\
\hline $26 \mathrm{~V} 1728$ & zniszczonych 38 domów i kamienic & $\begin{array}{l}\text { AGAD, AR, dz. VI, sygn. II-80a, } \\
\text { s. } 264\end{array}$ \\
\hline 2 VI 1737 & zniszczone $3 / 4$ miasta (w tym 10 kościołów) & „Kuryer Polski” 1737, nr 25 \\
\hline 21 III 1741 & $\begin{array}{l}\text { zniszczony kościół katedralny } \\
\text { pw. św. Stanisława Biskupa }\end{array}$ & J.I. Kraszewski, op. cit., s. 177 \\
\hline 11 VI 1748 & zniszczone niemal całe miasto & „Kuryer Polski” 1748, nr 604 \\
\hline 8 VI 1749 & $\begin{array}{l}\text { zniszczone niemal całe miasto; zginęło } \\
\text { kilkanaście osób }\end{array}$ & „Kuryer Polski” 1749, nr 666 \\
\hline $2 \mathrm{~V} 1751$ & $\begin{array}{l}\text { zniszczone } 3 \text { kamienice i kościół } \\
\text { pw. Świętej Trójcy, szpital; zginęło } 3 \text { ludzi }\end{array}$ & $\begin{array}{l}\text { AGAD, AR, dz. VI, sygn. II-80a, } \\
\text { s. 1790; „Kuryer Polski” 1751, nr } 765\end{array}$ \\
\hline $18 \mathrm{~V} 1753$ & $\begin{array}{l}\text { zniszczone } 3 \text { domy za Bramą Rudnicką, } \\
\text { zginęła } 1 \text { osoba }\end{array}$ & „Kuryer Polski” 1753, nr 876 \\
\hline $10 \mathrm{~V} 1754$ & zniszczonych ponad 30 domów & „Kuryer Polski” 1754, nr 44 \\
\hline 16 IV 1755 & $\begin{array}{l}\text { zniszczonych } 5 \text { domów w okolicy kościoła } \\
\text { pw. św. Jerzego na przedmieściu }\end{array}$ & „Kuryer Polski” 1755, nr 93 \\
\hline 5/6 VI 1756 & $\begin{array}{l}\text { zniszczone } 4 \text { kamienice w pobliżu } \\
\text { klasztoru prawosławnego }\end{array}$ & „Kuryer Polski” 1756, nr 152 \\
\hline
\end{tabular}

Relacje o pożarach przywodzą na myśl wizje apokaliptyczne ${ }^{295}$. „Kuryer Polski” opisujący kataklizm, który dotknął Wilno w 1748 r., przedstawił panujący

${ }^{294}$ AGAD, AR, dz. VI, sygn. II-80a, s. 1669.

295 Por. M. Rokicka, Gazety ulotne o klęskach żywiołowych - o wariantywności ich schematu kompozycyjnego, w: Staropolskie teksty i konteksty. Studia, t. 4, red. J. Malicki, D. Rott, Katowice 2003, s. 33-41. 
chaos w następujący sposób: „niemal ostatecznemu Sądowi zdał się ten dzień rownać, albowiem Słońce dymem záćmione było, prochy w sklepach lub kramach zapálone niby pioruny biły" ${ }^{296}$. Odzwierciedlonym w źródłach obrazom pożarów miejskich towarzyszą rozpacz i bezsilność. Rozmiary katastrofy niejednokrotnie potęgowała następująca jeszcze w tym samym roku kolejna klęska. Mieszkańcy Grodna w ciągu zaledwie czterech miesięcy 1753 r. przeżyli dwa pożary. 20 maja spłonęło 180 budynków chrześcijańskich i żydowskich ${ }^{297}$. Szalejący 12 września przez 6 godzin pożar pochłonął ponad 200 obiektów ${ }^{298}$.

Zjawiskiem $\mathrm{z}$ grupy hydrometeorów pojawiającym się często $\mathrm{w}$ okresie wiosenno-letnim jest grad. Pisząc o opadach gradu, zwracano uwagę na wielkość oraz kształt gradzin (bryłek lodu). Niekiedy jedynie odnotowywano fakt opadu $^{299} .14$ lipca $1731 \mathrm{r}$. grad uprzykrzył podróż Michałowi K. Radziwiłłowi między Białą, Mirem a Koreliczami w województwie nowogródzkim. Odnotował on w swoim diariuszu: „dzień niepogodny i grad spadł z taką zawieruchą jak w jesieni”, co przywodzi na myśl towarzyszący gradowi deszcz i prawdopodobnie chłód. Tego samego roku, na przełomie sierpnia i września w okolicy Wilna spadł grad o wyglądzie ośmiograniastych gwiazd („w ośmiugránach in forma gwiázd”). Autor w wydrukowanym doniesieniu nie omieszkał dodać, że zjawisko było nietypowe: „podobnego grádu nie widźieli, áni też iuż w podeszłym wieku będący nie pamiętáią" ${ }^{300}$. Relacja miała charakter dygresyjny, została zamieszczona między informacjami o pracach Trybunału Skarbowego i scenami z życia towarzyskiego elit szlacheckich oraz doniesieniem o miejscu rezydowania biskupa wileńskiego. Rok później, 2 czerwca 1732 r. w rejonie radziwiłłowskich Korelicz (województwo nowogródzkie) spadł nawalny grad, który powybijał zboże, spustoszył również lasy, łamiąc gałęzie i obdzierając korę z drzew, zabił także zwierzęta - Michał K. Radziwiłł wspomniał o martwych gęsiach, baranach, świniach, bydle rogatym i koniach. Zdarzały się incydenty, że spadające $\mathrm{z}$ wielkim impetem gradziny kaleczyły także ludzi. Radziwiłł nazwał wydarzenie „prawdziwą karą bożąa". Pięć dni po tragicznym wydarzeniu, 7 czerwca przyjechał do Radziwiłła pisarz grodzki i cześnik nowogródzki Aleksander Piotr Sowicz Korsak ze szczegółową informacją o spustoszeniach spowodowanych gradobiciem. Przywiózł również do pokazania "gałąź brzeziny i choiny” ułamane podczas feralnego dnia. Osobliwością było spadnięcie pod dworem Korsaka „bryły lodu”, której nawet 10 chłopów nie mogło ruszyć $\mathrm{z}$ miejsca ${ }^{301}$. Pojawianie się nieregularnych brył lodu znacznych rozmiarów w konsekwencji opadów gradu to zjawisko spotykane

\footnotetext{
${ }^{296}$ Z Wilna d. 15. Junij, „Kuryer Polski” 1748, nr 604.

${ }^{297} Z$ Grodna d. 30. Maji, „Kuryer Polski” 1753, nr 872.

298 Specyfikacya Miasta Grodna d. 12. Sept. Zgorzałego, „Kuryer Polski” 1753, nr 11

${ }^{299}$ BPAN-PAUKr, sygn. 977, k. 253v (Biała, 4 VII 1712).

${ }^{300}$ Z Wilna d. 2. 7bris, „Kuryer Polski” 1731, nr 90.

${ }^{301}$ AGAD, AR, dz. VI, sygn. II-80a, s. 497-498.
} 
również w naszych czasach. Znaczne kawały lodu mogą spadać na ziemię bądź też tworzą się w trakcie zjawiska regelacji, czyli ponownego zamarzania opadłych gradzin już na powierzchni ziemi po wcześniejszym ich stopieniu w rezultacie zwiększonego ciśnienia. Podczas zjawiska ciśnienie ulega obniżeniu do stanu początkowego. O ogromnej bryle lodu, która „spadła z nieba”, wspomniał Jan Antoni Chrapowicki w sierpniu 1679 r. ${ }^{302}$

Najczęściej gradziny osiągają średnicę 5-50 mm, ale zarówno wielkość, jak i kształt bywają różne. Pod koniec lipca $1741 \mathrm{r}$. w okolicy Mejszagoły (4 mile od Wilna) „y po innych mieyscach” spadł grad „wielkości jaia”, który wybił zboże $e^{303}$. 15 lat później, 13 lipca 1756 r. w okolicy miasta Kroże na Żmudzi spadł „nawalny” $\operatorname{grad~} \mathrm{z}$ „niespodziewaną burzą”. Zniszczył zboże na polach, a także pobił okna $\mathrm{w}$ domach „Z wielką szkodą ludzi”. Jak donosiła prasa, grad powybijał również okna w kościele, nie precyzując jednak w którym, a w Krożach (dekanat Wornie, diecezja żmudzka) znajdowały się wówczas dwa kościoły: parafialny pw. Niepokalanego Poczęcia NMP i oo. Jezuitów pw. Wniebowzięcia NMP ${ }^{304}$. Świadkowie twierdzili, że grad był „wielki iak orzech włoski”" ${ }^{305}$.

W źródłach odnajdujemy informacje na temat silnych wiatrów. Panujące wichry w znaczny sposób utrudniały prace polowe ${ }^{306}$. Prasa niekiedy podawała informacje na temat utrzymującej się kilka dni wietrznej pogody ${ }^{307}$. Informacje o warunkach utrudniających podróż znajdujemy w pamiętnikach. Stanisław Niezabitowski w swoim diariuszu wspominał przeciwności, jakie go spotkały 22 kwietnia 1697 r. milę od Horodziszcz (województwo nowogródzkie) podczas podróży razem z synem w kierunku Jatry. Jazdę utrudnił wir powietrzny („wicher kręcący”), który gwałtownie „napadł” podróżnych obawiających się powywracania $^{308}$. O bolączkach podróżniczych związanych $\mathrm{z}$ wiatrem pisał również Michał K. Radziwiłł. 24 października 1743 r. przeprawiał się przez Bug „w wielki barzo wiatr"309. Podobnie osiem lat później, 15 maja 1751 r., kiedy przepływał ze swoją świtą przez Niemen, „wicher powstał wielki”. Sytuacja stała się bardzo poważna, skoro nie omieszkał zanotować: „byłem na promie w wielkim niebezpieczeństwie"310. Ze źródeł wynika, że kwiecień i maj $1751 \mathrm{r}$. były wyjątkowo wietrzne. Również Hieronim F. Radziwiłł wybierający się w podróż do Dubowa odłożył

\footnotetext{
${ }^{302}$ W. Nowosad, R. Przybylak, K. Marciniak i K. Syta, op. cit., s. 58 (tabela).

${ }^{303}$ Z Wilna d. 29. Julij, „Kuryer Polski” 1741, nr 244.

${ }^{304}$ S. Litak, Atlas Kościoła łacińskiego w Rzeczypospolitej Obojga Narodów w XVIII wieku, Lublin 2006, s. 326, 410.

${ }^{305}$ Z Wilna dnia 9. Sierpnia, „Kuryer Polski” 1756, nr 161.

${ }^{306}$ Z Wilna d. 15. Iuly, „Kuryer Polski” 1731, nr 83, s. 357.

${ }^{307}$ Z Grodna d. 16. 7bris, „Kuryer Polski” 1731, nr 92, s. 395.

${ }^{308}$ S. Niezabitowski, op. cit., s. 148.

${ }^{309}$ AGAD, AR, dz. VI, sygn. II-80a, s. 1275.

${ }^{310}$ Ibidem, s. 1788.
} 
wyjazd z uwagi na chorobę, ale także "niemniej dla czasu srodze wietrznego" 311 . Jest powszechnie znany wpływ gwałtownego wiatru na samopoczucie, objawiający się osłabieniem, obniżeniem zdolności do wysiłku, utrudnieniami w oddychaniu, niepokojem, bezsennością. Charakterystyczne efekty akustyczne towarzyszące wiatrom, takie jak szumy, gwizdy, wycia, oddziałują negatywnie na psychikę $e^{312}$.

„Kuryer Polski” w 1750 r. donosił o powstaniu 10 kwietnia po południu „zbytecznego wichru" na Dźwinie koło Witebska. Silny wiatr przeszkodził żegludze, a także ludziom będącym na brzegu „znaczną uczynił trwogę”. Utopiło się kilka osób. Autor relacji poświęcił dużo miejsca katastrofie szkuty przewożącej ludzi do miasta na targ. Chaos i straty okazały się większe, gdyż szkuta była przepełniona, a znajdowały się na niej - oprócz ludzi - wozy i zwierzęta. Jak wspominał autor, „wiele ludzi potopiło”. Z rozszalałego żywiołu uszli tylko „niektórzy”, m.in. przewoźnicy i pasażerowie, którzy by wypłynąć, chwytali się koni i części szkuty. Niezwykłe wydarzenie, które zdaniem autora relacji było godne podkreślenia, to ocalenie dwuletniego dziecka, które do brzegu zostało przyniesione falami („żywo przypłynione zostało") ${ }^{313}$.

Temat ładnej pogody poruszano w omawianych źródłach okazjonalnie i sporadycznie. O słonecznej, pięknej pogodzie wspominano najczęściej przy okazji pomyślnego odprawienia oficjalnych ceremonii, przyjęć, parad itp., którym ona sprzyjała ${ }^{314}$. Wystawnym obchodom różnych uroczystości towarzyszyły fajerwerki i iluminacje, zatem pomyślne wykonanie podobnych widowisk wywoływało ulgę, że nie zostały zakłócone nieprzewidzianymi czynnikami naturalnymi ${ }^{315}$. Podobnie w przypadku obrzędów religijnych, np. procesji, koronacji obrazu czy innych nabożeństw ${ }^{316}$.

Pisano o pogodzie w momencie nastania jej po długim „niepogodnym” bądź niesprzyjającym czasie (np. słoneczna, ciepła pogoda po długotrwałych mrozach) ${ }^{317}$. Przyjście jej uważano za łaskę Bożąą ${ }^{318}$. Jako synonim słowa „pogoda” używano niekiedy wyrazu „aerja”, często też to słowo rozumiano jako „stan” pogody ${ }^{319}$. Zjawisko pięknej pogody przynosiło radość i zadowolenie, jednak było tak mało interesujące, że generalnie przyjmowano je obojętnie i przeważnie nie zostawiało odzwierciedlenia w źródłach. W materiale pamiętnikarskim odnajdujemy zdania świadczące o pochwale warunków klimatycznych Rzeczypospolitej.

${ }^{311}$ Ibidem, sygn. II-81, k. 160.

312 J. Grączewski, op. cit., s. 66.

${ }^{313}$ Z Witebska d. 17. Apr., „Kuryer Polski” 1750, nr 711.

${ }^{314}$ M. Matuszewicz, op. cit., t. 1, s. 343.

${ }^{315}$ Z Wilna d. 6. Augusti, „Kuryer Polski” 1759, nr 33; Addytament do gazet, „Kuryer Polski” 1759, nr 33.

${ }^{316}$ Z Wilna d. 25. Junii, „Kuryer Polski” 1753, nr 876; „Kurier Litewski” 1761, nr 39, Supplement do gazet.

${ }^{317}$ Z Wilna d. 9. Junii, „Kuryer Polski” 1742, nr 289.

${ }^{318}$ Ibidem; S. Niezabitowski, op. cit., s. 242 (11 VIII 1699, Słuck).

${ }^{319}$ Z Wilna d. 25. Junii, „Kuryer Polski” 1753, nr 876. 
Oceniający je Jędrzej Kitowicz pisał, że „W Polszcze aura umiarkowana, lato z zimą równe"320.

Wiążące się niejednokrotnie z czynnikami meteorologicznymi, choć również występujące niezależnie od nich, są epidemie chorób zakaźnych zarówno ludzi, jak i zwierząt. W omawianych źródłach znajdujemy wzmianki mówiące o chorobach zwierząt gospodarskich (głównie bydła i koni) i stanowiących ich konsekwencję pomorach. Krzysztof Zawisza pisząc o licznych katastrofach naturalnych i klęskach związanych $\mathrm{z}$ toczącą się wielką wojną północną, wspomniał ciężką zarazę bydła i koni na ziemiach litewskich w latach 1711-1714 ${ }^{321}$. Pomór bydła odnotowano w województwie wileńskim w sierpniu 1719 r. podczas nieustannie padających deszczy ${ }^{322}$. Marcin Matuszewicz pojawienie się zarazy bydła w województwie brzeskolitewskim w 1744 r. tłumaczył obecnością na niebie komety 323 , twierdząc, że pomór zwierząt gospodarczych występuje periodycznie, co kilkanaście lat, powodując w jednym miejscu „po kilka razy” uszczerbek hodowli ${ }^{324}$. Na początku sierpnia 1752 r. burmistrz Witebska, Gabriel Kuriłowicz Awierko zanotował: „bydło, krowy wszystkie pozdychali w Witebsku”325. Duża śmiertelność bydła w Wilnie i okolicy miała miejsce w lipcu 1755 r. ${ }^{326} \mathrm{~W}$ listopadzie $1761 \mathrm{r}$. na pograniczu litewsko-pruskim panowała zaraza bydła i koni - jak donosił „Kurier Litewski: „Gorączka tak je pali, iż wnętrzności spiekłe w proch się rozsypują”327.

$\mathrm{W}$ relacjach niekiedy odnotowywano przypadki przeziębieńn ${ }^{228}$, ale też fakty niezidentyfikowanych zaraźliwych chorób będących przyczyną „częstych zgonów”. W kwietniu 1731 r. „Kuryer Polski” donosił o „ciężkich chorobach” panujących w województwie mińskim wśród szlachty i ludności wiejskiej. Odnotowane zostały nazwiska osób, wywodzących się z ziemskich elit urzędniczych, które „po krotkiey chorobie z tego świata zeszli", mianowicie m.in. podstoli brasławski Bykowski ${ }^{329}$

320 J. Kitowicz, Pamiętniki czyli Historia polska, oprac. P. Matuszewska, komentarz Z. Lewinówna, Warszawa 1971, s. 580.

${ }^{321}$ Pamiętniki Krzysztofa Zawiszy..., s. 364.

322 „Poczta Królewiecka” 1719, nr 37, s. 296.

${ }^{323}$ Była to kometa jednopojawieniowa C/1743 X1, od nazwisk odkrywców zwana Kometą Klinkenberg-de Chéseaux. S.R. Brzostkiewicz, Sławne komety, „Urania. Miesięcznik Polskiego Towarzystwa Miłośników Astronomii" 1984, nr 5, s. 136-137; D.K. Yeomans, Komety od starożytności do współczesności, w mitach, legendach i nauce, przeł. A.S. Pilski, Warszawa 1999, s. 146.

${ }^{324}$ M. Matuszewicz, op. cit., t. 1, s. 218-219.

${ }^{325}$ Витебская тетопис..., s. 230.

${ }^{326}$ Z Wilna dnia 14 Lipca, „Kuryer Polski” 1755, nr 105.

${ }^{327}$ Z Wilna d. 20 Listopada, „Kurier Litewski” 1761, nr 47.

${ }^{328}$ M. Matuszewicz, op. cit., t. 1, s. 855 (XII 1757), t. 2, s. 191 (zima 1762); Z Wilna d. 12 Lutego, „Kurier Litewski” 1762, nr 7.

${ }^{329}$ W źródle został odnotowany urząd podstolego „bacławskiego”, ale najprawdopodobniej jest to pomyłka drukarska i chodzi w tym miejscu o podstolego brasławskiego. Autorzy wydawnictwa Urzędnicy Wielkiego Księstwa Litewskiego odnotowali w 1713 r. podstolego brasławskiego Jana Stanisława Bykowskiego (Urzędnicy Wielkiego Księstwa Litewskiego. Spisy, t. 1: Województwo 
i pisarz miński Unichowski ${ }^{330}$. Podobne nagłe śmierci zostały zauważone na początku maja $1752 \mathrm{r}$. w województwie wileńskim. Tak zmarli leczący się w Sejnach marszałek oszmiański Antoni Józef Sulistrowski i kurujący się w Wilnie oboźny smoleński, starosta samnicki Jan Antoni Dylewski. „Kuryer Polski” dodawał: „Inni zaś rożnego stanu ludzie, tak tu w Wilnie, iako też po partykularzach nie długo choruiąc umieraią"331. Trzy lata później, na początku 1755 r. zostały odnotowane nagłe zgony w parafii wieliskiej w województwie smoleńskim ${ }^{332}$.

Hieronim F. Radziwiłł pisał, że pod koniec grudnia 1750 r. otrzymał już trzecią wiadomość o zarazie „grasującej” w Nalibokach. Zawiadomienia miały go przestraszyć i nie dopuścić do przyjazdu. Radziwiłł mimo ostrzeżeń zjawił się w Nalibokach z bratem Michałem Kazimierzem, dzień po otrzymanej wiadomości (29 XII) i osobiście zapoznawszy się ze stanem zaniedbanego gospodarstwa, zrozumiał, dlaczego nie życzono sobie jego nagłej wizyty: „gdzie w rzeczy samej poznałem po pałacu opuszczonym, że niezbyt mej tu żądano ile tak prędko bytności”333.

Największą trwogę budziła dżuma ${ }^{334}$. W latach 1709-1710 w Wilnie miało umrzeć aż 23000 - 33700 ludzii ${ }^{335}$. W źródłach odnajdujemy opisy stanów paniki przed zarazą i ucieczek dużych skupisk ludzi ${ }^{336}$. Przejmujący opis dżumy na Litwie pozostawił bazylianin o. Jan Oleszewski. Autor relacji twierdził, że zaraza, szerząca się początkowo na Żmudzi, dotarła na Wileńszczyznę, przetaczając się wcześniej przez województwo trockie i Kowieńszczyznę. Wzrost umieralności w Wilnie spowodował panikę i masową ucieczkę mieszkańców oraz ludności okolicznej. Charakterystyczne obrazy dla autora stanowiły zatłoczone drogi, pełne taborów migrujących z całym dobytkiem $\mathrm{w}$ nieznane bądź grupy ludzi kryjących się w lasach. Wysoka śmiertelność spowodowała pozostawianie całych pustych gospodarstw i wsi. Zaniedbywano prace gospodarskie, nie zbierano dojrzałego zboża, bydło chodząc samopas, dziczało. Jadąc drogami, można było znaleźć mnóstwo porzuconych rzeczy, których nikt nie chciał zabrać, bojąc się zarazy, a poniewierające

wileńskie XIV-XVIII wiek, red. A. Rachuba, oprac. H. Lulewicz, A. Rachuba, P.P. Romaniuk, współpraca U. Jemialianczuk, A. Macuk, Warszawa 2004, s. 571, nr 4457).

${ }^{330}$ Z Wilna d. 2. April, „Kuryer Polski” 1731, nr 68.

${ }^{331}$ Z Wilna d. 13. Maji, „Kuryer Polski” 1752, nr 818.

${ }^{332}$ Z Wilna d. 19. Marca, „Kuryer Polski” 1755, nr 88.

${ }^{333}$ AGAD, AR, dz. VI, sygn. II-81, k. 233v.

${ }^{334}$ Por.: J. Delumeau, Strach $w$ kulturze Zachodu XIV-XVIII w. Oblężony ogród, przeł. A. Szymanowski, oprac. J. Gondowicz, Warszawa 2011, s. 133-159; J. Kracik, Pokonać czarna śmierć. Staropolskie postawy wobec zarazy, Kraków 1991, s. 54-60; Ł. Miechowicz, Zaraza i „morowe mogity" na nowożytnej wsi, w: Epidemie, klęski, wojny. Funeralia Lednickie - spotkanie 10, red. W. Dzieduszycki, J. Wrzesiński, Poznań 2008, s. 289-290; A. Górski, Wspomnienie zarazy 1709 roku $w$ zachowanych artefaktach epigraficznych, w: Epidemie..., s. 297.

${ }^{335}$ A. Karpiński, $W$ walce..., s. 334.

${ }^{336}$ J. Erdman do K.S. Radziwiłła, 2 V 1709, [miejsce nadania nieczytelne], AGAD, AR, dz. V, sygn. 3596, s. 128. 
się w różnych miejscach ludzkie zwłoki były rozszarpywane przez psy. Smutny obraz kraju dopełniały rzucające się w oczy pustka i wyludnienie. Choroba rozwijała się błyskawicznie, powodując zgon najczęściej po trzech, a najpóźniej po pięciu dniach od wystąpienia pierwszych objawów. Wrażenia o. Oleszewskiego po przyjeździe do Wilna, które odwiedził zaraz po przejściu zarazy, przywiodły smutną konstatację: „ciężka była ręka Boska nad tym miastem”337. Wyludnione Wilno ukazywało żałosny widok: puste ulice, zanik działalności handlowej i rzemieślniczej. Niewielka liczba wykwalifikowanych majstrów przyczyniła się do wzrostu cen za świadczone usługi. W greckokatolickiej cerkwi oo. Bazylianów z powodu braku śpiewaków liturgię czytano ${ }^{338}$.

Ton tekstów powstających podczas zawirowań polityczno-społecznych był utrzymany w atmosferze permanentnej apokaliptycznej trwogi. Opisy klęsk tych czasów stanowią nie tylko kronikarski zapis faktów epoki, ale przede wszystkim rejestrację kondycji psychicznej współczesnych, będąc wyrazem lęków i niepokojów egzystencjonalnych oraz uświadomionej bezsilności. Relacje te to także odzwierciedlenie głębokiego kryzysu światopoglądowego, czego przejawem stały się frustracje, okrucieństwo, prymitywizm zachowań ludzkich, deprecjacja wartości moralnych ${ }^{339}$. Powstało wówczas wiele tekstów zawierających wyimaginowany obraz niecodziennych zjawisk przyrodniczych, w których dopatrywano się cech nadprzyrodzonych.

Po kataklizmach wojennych pierwszych dekad XVIII w. zanarchizowana Rzeczpospolita, tracąca znaczenie na scenie międzynarodowej, pozostała na uboczu europejskich konfliktów, dzięki czemu mogła zająć się przynajmniej fragmentaryczną odbudową i naprawą poniesionych szkód materialnych i spustoszeń zaistniałych $\mathrm{w}$ sferze świadomości mieszkańcó $\mathrm{w}^{340}$. Procesom tym towarzyszyła transfiguracja sposobu myślenia części społeczeństwa idąca w parze z zachodnioeuropejskimi nowinkami oświeceniowymi. Czasy pokoju i wojny miały ogromne znaczenie dla form postrzegania zjawisk naturalnych i odzwierciedlania tychże w materiale narracyjnym. Głównymi determinantami opisywania fenomenów przyrodniczych były kwestie informacyjne i publicystyczne związane z zainteresowaniem poszczególnymi zjawiskami czy osobliwościami. Doniesienia o sytuacji meteorologicznej przybierały postać przestróg, prognostyków bądź po prostu anegdot i dygresji, a $\mathrm{z}$ drugiej strony istotną rolę odgrywało zagadnienie praktyczne, któremu przyświecało formułowanie komunikatów dotykających kwestii gospodarczych, zdrowotnych oraz możliwości przemieszczania się i podróżowania. Nie sposób nie dostrzec obaw czy lęków przed nieprzewidywalnymi i nieokiełznanymi siłami przyrody i żywiołów. Upowszechnianie doniesień o zjawiskach

\footnotetext{
337 Abrys..., s. 85.

338 Ibidem.

${ }^{339}$ Por. A. Roćko, „Honor nader czczony!” - o wpływie wojen, żywiołów, niepokojów na postawy Sarmatów czasów saskich, w: Między barokiem a oświeceniem..., s. 150.

340 J. Staszewski, August III Sas, Wrocław 1989, s. 196, 225, 262-263.
} 
pogodowych, wszelkich anomaliach, katastrofach czy kuriozach przyrodniczych świadczy o predylekcji twórców tekstów i ich potencjalnych odbiorców do wszelkiego typu nowinek i sensacji, jawiąc się również jako drobiazgowe rejestrowanie wydarzeń epoki ${ }^{341}$.

Społecznym zainteresowaniem cieszyły się roczne prognostyki pogodowe zamieszczane w kalendarzach. Stosunek do nich wydaje się jednak dość ambiwalentny, gdyż zdawano sobie sprawę, że publikowane w nich ekstrapolacje nie zawsze były trafne ${ }^{342}$. Niemniej jednak kalendarze stanowiąc popularne i łatwo dostępne wydawnictwa, kształtowały postawy czytelników ${ }^{343}$, wpływając na charakter percepcji zjawisk naturalnych oraz na pokutujące powszechnie przesądy.

\section{Atmospheric phenomena, meteorological elements and natural disasters in Lithuania in years 1697-1763 in some narrative sources Summary}

The article concerns on the question of meteorological phenomena and their consiquences, such as hydrological phenomena and natural disasters, on the territory of the Grand Dutchy of Lithuania in the years 1697-1763 through the prism of narrative sources. Author analyzed the problems of everyday life in terms of weather phenomena. He also mentioned about the way of naming these normal and abnormal wather cirumstances. Moreover, in the article were described natural disasters on the Lithuania such as floods, famine, conflagrations, locust infestations, epidemics of infectious diseases. References used by author in the process of writing this article relate mainly to observations recorded during the journey. Some of them also describe the conditions which had facilitating or impeding impact on travelling and leisure. Some sources relate to economic issues.

${ }^{341}$ P. Kowalski, Świat Andrzeja Komonieckiego kronikarza Żywca. Studia z antropologii historycznej, Wrocław 2010, s. 120-121.

${ }^{342}$ Jan Chryzostom Pasek notując wydarzenia towarzyszące nietypowej zimie 1682 r., stwierdził: „W Przewodni Tydzień śnieg i mróz wielki, że mógł saniami jechać. A panowie minucyjarze nic o tym nie napisali” (J.Ch. Pasek, Pamiętniki, oprac. R. Pollak, Warszawa 1989, s. 231). Również Franciszek Szyrma piszący o nadzwyczajnych mrozach 1709 r. wspomniał, że twórcy kalendarzy nie przewidzieli ekstremów meteorologicznych (BTNP, rkps 113, k. 96). Analizująca kalendarze drukowane w epoce oświecenia Małgorzata Gorczyńska przytoczyła przykłady rękopiśmiennych adnotacji na stronach wydawnictw z podanym rzeczywistym stanem pogody w danym dniu oraz uszczypliwymi komentarzami wydrwiwającymi błędne prognozy (M. Gorczyńska, Popularyzacja wiedzy w polskich kalendarzach okresu Oświecenia (1737-1821), Lublin 1999, s. 200).

${ }^{343}$ B. Rok, op. cit., s. 146-147. 


\section{Bibliografia}

\section{Źródła rękopiśmienne}

Archiwum Główne Akt Głównych w Warszawie

Archiwum Radziwiłłów

dz. II, sygn. 12, dz. V, sygn. 17362/I, 3596, dz. VI, sygn. II-80a, II-81

Biblioteka im. Zielińskich Towarzystwa Naukowego Płockiego w Płocku rkps 113

Biblioteka Narodowa, Biblioteka Ordynacji Zamojskiej

sygn. 837,941

Biblioteka Państwowej Akademii Nauk - Państwowej Akademii Umiejętności w Krakowie sygn. 977

\section{Źródła drukowane}

Abrys domowey nieszczęsliwosci y Wnętrznej Niesnaski, Woyny, Korony Polskiey y Wielkiego Xięstwa Litewskiego Pro Informatione Potomnym następujacym czasom Przez iedna Zakonna Osobe swiatu pokazany y z Załoscia wyrażony Anno 1721, wyd. F.K. Kluczycki, Kraków 1899.

Bartoszewicz K., Tadeusz Ogiński wojewoda trocki i jego pamiętnik (odbitka z „Przegladu Historycznego"), Warszawa 1913.

Bystrzonowski W., Informacja matematyczna rozumie ciekawego Polaka świat cały, niebo, y ziemię, y co na nich jest $w$ trudnych kwestyach y praktyce, jemuż ułatwiające, Lublin 1743.

Chmielowski B., Nowe Ateny albo akademia wszelkiey scyencyi petna, na rozne tytuly iak na classes podzielona, madrym dla memoryału, idiotom dla Nauki, politykom dla Práktyki, melancholikom dla rozrywki, cz. 1-4, Lwów 1754-1756.

Chrapowicki J.A., Diariusz, cz. 1: Lata 1656-1664, oprac. T. Wasilewski, Warszawa 1978, cz. 2: Lata 1665-1669, oprac. A. Rachuba, T. Wasilewski, Warszawa 1988, cz. 3: Lata 1669-1673, oprac. L.A. Wierzbicki, Warszawa 2009.

Duńczewski S., Ciekawosc o komecie Roku Panskiego MDCCXLIV dalsza swiatła obrotu y procedencyi iego koniekturą, az do skonczenia apparicyi na horizoncie zamoyskim, Zamość 1744.

Duńczewski S., Relacya II O Meteorach, álbo Powietrznych apparycyach dźiwnych y osobliwszych $w$ Polszcze y W.X.L. etc., w: Raritates Polskie W.X. Litewskiego y prowincyi do nichze należacych, Kalendarz 1749, Zamość 1748, s. [ $\left.\mathrm{L}_{2}\right]-\left[\mathrm{M}_{2}\right]$ [artykuł jest częścią rozdziału: Wiadomosc III., O Zyzności Polskiey y niezwyczaynych Meteorach, z rożnemi przypádkami osobliwemi].

Komoniecki A., Chronografia albo Dziejopis żywiecki, wyd. S. Grodziski, I. Dwornicka, Żywiec 1987. Linde M.S.B., Stownik języka polskiego, t. 2, cz. 2, Warszawa 1811.

Matuszewicz M., Diariusz życia mego..., oprac. B. Królikowski, komentarz Z. Zielińska, t. 1-2, Warszawa 1986.

Niezabitowski S., Dzienniki 1695-1700, oprac. A. Sajkowski, Poznań 1998.

Nowa księga przysłów i wyrażeń przysłowiowych polskich, red. J. Krzyżanowski, t. 1, Warszawa 1969, t. 2, Warszawa 1970, t. 3, Warszawa 1972.

Pamiętnik Felicyana Junoszy-Piaskowskiego podstolego podlaskiego, majora J.K. Mości począwszy od roku 1690, Lwów 1865.

Pamiętniki Krzysztofa Zawiszy, wojewody mińskiego. (1666-1721), wyd. J. Bartoszewicz, Warszawa 1862. 
Pasek J.Ch., Pamiętniki, oprac. R. Pollak, Warszawa 1989.

Rękopism x. Bagińskiego dominikana Prowincyi Litewskiéj (1747-1784 r.) wydany przez E. Tyszkiewicza, Wilno 1854.

Rzączyński G., Auctuarium historiae naturalis curiosae Regni Poloniae Magni Ducatus Lithuaniae, annexarumque provinciarum, Gedani 1745.

Rzączyński G., Historia naturalis curiosa Regni Poloniae, Magni Ducatus Lituaniae, annexarumq; provinciarum, in tractatus $X X$, Sandomiriae 1721.

Słownik języka Jana Chryzostoma Paska, red. nacz. H. Koneczna, t. 2, Wrocław-Warszawa-Kraków-Gdańsk 1973.

Słownik polszczyzny XVI wieku, red. nacz. M.R. Mayenowa, t. 7, Wrocław-Warszawa-KrakówGdańsk 1973, t. 24, Warszawa 1996.

Słownik staropolski, red. nacz. S. Urbańczyk, t. 6, Wrocław-Warszawa-Kraków-Gdańsk 1970-1973.

Troc M.A., Nowy dykcyonarz to iest mownik polsko-niemiecko-francuski z przydatkiem przysłow potocznych, przestrog gramatycznych, lekarskich, matematycznych, fortyfikacyjnych, żeglaskich, łowczych i inszym naukom przyzwoitych wyrazow, tom trzeci, Leipzig 1779.

Wilhelma Schlemüllera Dyarysz podróży polskiej na sejm grodzieński Roku Pańskiego 1752 odbytej $z$ rękopisu Archiwum Królewieckiego na widok publiczny przez Wacława Gizberta-Studnickiego archiwariusza miasta Wilna wydany dla użytku rodaków $z$ łacińskiego na język polski przetłumaczył x. kanonik J. Rosołowski, „Litwa i Ruś. Miesięcznik ilustrowany, poświęcony kulturze, dziejom, krajoznawstwu i ludoznawstwu", IV 1912, t. 2, z. 1.

Wiśniowiecki M.S., Dla pamięci co się którego roku działo, w: Podole, Wołyń, Ukraina. Obrazy miejsc i czasów przez Aleksandra Przezdzieckiego, t. 1, Wilno 1841.

Włodek I., Slownik polski dawny Czyli Zebranie słow dawnych zaniedbanych Polskich $z$ ich tłömaczeniem, w: idem, O naukach wyzwolonych w powszechnosci, i szczegulnosci ksiegi dwie, Rzym 1780.

Wyrwicz K., Geografia czasow teraznieyszych albo opisanie naturalne y polityczne Krolestw, Państw, Stanow wszelakich, ich rządu, praw, rzemiost, handlu, przemysłu, przymiotow, obyczaiow \&c. ku pozytkowi narodowey młodzi wydana, t. 1, Warszawa 1768.

Витебская летопис составленная мещанами: Михаилом Панцьрнымъ (896-1709), Иваномъ Чарновскимъ (1601-1757), Гавріилом и Стефаномъ Аверками (1578-1768), w: Сборникъ тетописей относящихся къ исторіи южной и западной Руси, изданный Коммиссіею для разбора дневнихъ актовъ, состоящей при Кіевскомъ, Подольскомъ и Волынскомъ Генераль-Губернаторе, Кіевъ 1888, s. 213-236.

Путешествіе стольника П.А. Толстаго 1697-1699, „Русскїй Архивъ” 1888, nr 2, 8.

\section{Czasopisma}

„Kurier Litewski” 1761, nr 39, 40, 42, 47, 51; 1762, nr 7, 23-26, 29, 31, 43, 52; 1763, nr 2, 11, 13,22

„Kuryer Polski” 1730, nr 17, 52; 1731, nr 62, 68, 73, 74, 78, 83, 88, 90, 92, 93, 95-97, 105; 1732, nr 126; 1733, nr 196, 1737, nr 6, 25; 1740, nr 161, 178, 202; 1741, nr 221, 237, 244, 247, 249; 1742, nr 272, 274, 282, 284, 287, 289; 1744, nr 371; 1746, nr 500; 1748, nr 603, 604, 608, 611, 613-615; 1749, nr 649, 660, 665, 666, 671, 674, 676; 1750, nr 709, 711; 1751, nr 765, 770, 772; 1752 , nr 818, 830, 831, 834; 1753, nr 872, 876, 11; 1754, nr 44; 1755, nr 88, 124, 93, 101, 105, 106; $1756, \mathrm{nr} 138,151,152,161 ; 1757, \mathrm{nr} 15 ; 1758, \mathrm{nr} 22 ; 1759, \mathrm{nr} 9,33,38$

„Kuryer Warszawski” 1761, nr 11

„Poczta Królewiecka” 1718, nr 2; 1719, nr 28, 37; 1720, nr 31, 40

„Wiadomości Uprzywileiowane Warszawskie” 1763, nr 84 


\section{Opracowania}

Achremczyk S., Człowiek doby baroku a środowisko, w: Życie codzienne na dawnych ziemiach pruskich. Człowiek a środowisko, red. H. Królikowska, Olsztyn 1999, s. 32-39.

Adamczyk W., Ceny w Lublinie od XVI do końca XVIII wieku, Lwów 1935.

Bazak J., Klęski elementarne $w$ życiu Jarosławia i okolic w XVII i pierwszej połowie XVIII wieku, „Rocznik Stowarzyszenia Miłośników Jarosławia” 2002-2004, t. 15, s. 47-70.

Bąkowski-Kois D., Zarządcy dóbr Elżbiety Sieniawskiej. Studium z historii mentalności 1704-1726, Kraków 2005.

Biometeorologia człowieka, red. J. Jankowiak, Warszawa 1976.

Briggs J.M., Aurora and Enlightenment. Eighteenth-century explanations of the Aurora borealis, „Isis” 1967, t. 58, s. 491-503.

Brzostkiewicz S.R., Sławne komety, „Urania. Miesięcznik Polskiego Towarzystwa Miłośników Astronomii” 1984, nr 5, s. 136-137.

Cerveny R., Wielkie katastrofy i anomalie klimatyczne w dziejach, przeł. I. Stąpor, Warszawa 2008.

Delumeau J., Strach w kulturze Zachodu XIV-XVIII w. Oblężony ogród, przeł. A. Szymanowski, oprac. J. Gondowicz, Warszawa 2011.

Dobrowolski A.B., Historja naturalna lodu, Warszawa 1923.

Epidemie, klęski, wojny. Funeralia Lednickie - spotkanie 10, red. W. Dzieduszycki, J. Wrzesiński, Poznań 2008.

Fara P., Lord Derwentwater's Lights. Prediction and the Aurora Polaris, „Journal for the History of Astronomy", VIII 1996, t. 27, nr 3, s. 239-258.

Filipiak J., Obserwacje i pomiary opadów atmosferycznych w Gdańsku w XVIII wieku, w: Wahania klimatu $w$ różnych skalach przestrzennych i czasowych, red. K. Piotrowicz, R. Twardosz, Kraków 2007, s. 365-373.

Gdy nadciagała wielka woda. Klęski powodzi na ziemiach polskich, red. E. Kościk, Wrocław 2013.

Gierowski J., Między saskim absolutyzmem a złota wolnością. Z dziejów wewnętrznych Rzeczypospolitej w latach 1712-1715, Wrocław 1953.

Gilarski M., Łowce - parafie, rozwój gospodarczy oraz najazdy nieprzyjacielskie i klęski żywiołowe do 1772 roku, „Rocznik Historyczno-Archiwalny” 2000, t. 14, s. 21-61.

Gorczyńska M., Popularyzacja wiedzy w polskich kalendarzach okresu Oświecenia (1737-1821), Lublin 1999.

Grączewski J., Wplyw pogody na zdrowie człowieka (uwagi lekarza o biometeorologii), Warszawa 1972.

Greenler R., Tęcze, glorie i halo czyli niezwykłe zjawiska optyczne w atmosferze, przeł. M. Krzyżanowska, Warszawa 1998.

Häckel H., Pogoda i klimat, przeł. M. Skalska, Warszawa 2009.

Historia astronomii w Polsce, t. 1, red. E. Rybka, Wrocław-Warszawa-Kraków-Gdańsk 1975.

Historia nauki polskiej, t. 2: Barok, Oświecenie, red. B. Suchodolski, Wrocław-Warszawa-Kraków 1970.

Hoszowski S., Klęski elementarne w Polsce w latach 1587-1648, w: Prace z dziejów Polski feudalnej ofiarowane Romanowi Grodeckiemu w 70 rocznicę urodzin, red. Z. Budkowa i in., Warszawa 1960, s. 453-465.

Isajew S.I., Puszkow N.W., Zorze polarne, przeł. M. Kozłowski, Warszawa 1961.

Janiszewski P., Żywioły w stużbie propagandy, czyli po czyjej stronie stoi Bóg. Studium klęsk i rzadkich fenomenów przyrodniczych u historyków Kościoła IV i V wieku, w: Chrześcijaństwo u schyłku starożytności. Studia źródłoznawcze, t. 3, red. T. Derda, E. Wipszycka, Kraków 2000, s. 11-191. 
Jukniewicz F., Zjawiska meteorologiczne i stan urodzajów oraz pomory w Polsce w latach 1697-1750, „Sprawozdania Towarzystwa Naukowego we Lwowie”, R. 17, 1937 [1939], z. 1, s. 63-70.

Kaczyńska E., Wizerunek własny człowieka polskiego baroku (Pamiętniki Krzysztofa Zawiszy), „Litteraria" 2012, t. 39, s. 49-58.

Karpiński A., Biedota miejska wobec zaraz i innych klęsk żywiołowych w Warszawie w latach 15261655, „Rocznik Warszawski” 1981, t. 16, s. 81-121.

Karpiński A., $W$ walce z niewidzialnym wrogiem. Epidemie chorób zakaźnych $w$ Rzeczypospolitej w XVI-XVIII wieku i ich następstwa demograficzne, społeczno-ekonomiczne i polityczne, Warszawa 2000.

Kowalski P., Powódź. Żywioły w Andrzeja Komonieckiego Chronografii, albo Dziejopisie żywieckim, w: Pejzaże kultury. Prace ofiarowane Profesorowi Jackowi Kolbuszewskiemu w 65. rocznice Jego urodzin, red. W. Dynak, M. Ursel, Wrocław 2005, s. 70-86.

Kowalski P., Świat Andrzeja Komonieckiego kronikarza Żywca. Studia z antropologii historycznej, Wrocław 2010.

Kozłowska-Szczęsna T., Błażejczyk K., Krawczyk B., Bioklimatologia człowieka. Metody i ich zastosowanie $w$ badaniach bioklimatu Polski, Warszawa 1997.

Kozłowska-Szczęsna T., Krawczyk B., Kuchcik M., Wplyw środowiska atmosferycznego na zdrowie i samopoczucie człowieka, Warszawa 2004.

Kracik J., Pokonać czarna śmierć. Staropolskie postawy wobec zarazy, Kraków 1991.

Kraszewski J.I., Wilno od początków jego do roku 1750, t. 2, Wilno 1840.

Kroczak J., „Jeśli mię wieźdźba prawdziwa uwodzi...” Prognostyki i znaki cudowne w polskiej literaturze barokowej, Wrocław 2006.

Kuchowicz Z., Człowiek polskiego baroku, Łódź 1992.

Kuchowicz Z., Z badań nad stanem biologicznym społeczeństwa polskiego od schyłku XVI do końca XVIII wieku, Łódź 1972.

Kuklo C., Demografia Rzeczypospolitej przedrozbiorowej, Warszawa 2009.

Kupiszewski W., Słownictwo meteorologiczne w gwarach i historii języka polskiego, Wrocław-Warszawa-Kraków 1969.

Limanówka D., Rekonstrukcja warunków klimatycznych Krakowa w pierwszej połowie XVI wieku, Warszawa 2001.

Litak S., Atlas Kościoła łacińskiego w Rzeczypospolitej Obojga Narodów w XVIII wieku, Lublin 2006.

Malewicz M.H., Zjawiska przyrodnicze w relacjach dziejopisarzy polskiego średniowiecza, WrocławGdańsk 1980.

Maliszewski K., Obraz świata i Rzeczypospolitej w polskich gazetach rękopiśmiennych z okresu późnego baroku. Studium $z$ dziejów kształtowania się i rozpowszechniania sarmackich stereotypów wiedzy i informacji o Theatrum Mundi, Torun 1990.

Maliszewski K., W kręgu staropolskich wyobrażeń o świecie, Lublin 2006.

Matuszko D., Chmury i pogoda, Kraków 2009.

Mergentaler J., Stońce - Ziemia, Warszawa 1994.

Michalczewski J., Średnia temperatura dobowa $w$ Warszawie w latach 1760-1763, „Przegląd Geofizyczny" 1988, t. 33, z. 4, s. 473-478.

Między barokiem a oświeceniem. Wojny i niepokoje czasów saskich, red. K. Stasiewicz, S. Achremczyk, Olsztyn 2004.

Moszyński K., Kultura ludowa Słowian, cz. 2: Kultura duchowa, Kraków 1934.

Motylewicz J., Straty i zniszczenia wojenne oraz klęski elementarne $w$ miastach ziemi przemyskiej i sanockiej w pierwszej połowie XVIII wieku, „Studia Przemyskie” 1993, t. 1, s. 71-84.

Nadolski B., Leksykon liturgii, Poznań 2006.

Namaczyńska S., Kronika klęsk elementarnych $w$ Polsce i $w$ krajach sąsiednich $w$ latach 1648-1696, t. 1: Zjawiska meteorologiczne i pomory, Lwów 1937. 
Nowosad W., Przybylak R., Marciniak K., Syta K., Diariusz Jana Antoniego Chrapowickiego jako źródło do badań klimatu w Rzeczypospolitej w drugiej połowie XVII wieku, „Klio” 2007, nr 9, s. $21-60$.

Od powietrza, głodu, ognia i wojny... Klęski elementarne na przestrzeni wieków, red. T. Głowiński, E. Kościk, Wrocław 2013.

Oliński P., Warunki pogodowe w Toruniu i okolicach $w 1$. połowie XVIII wieku w świetle źródeł narracyjnych, „Rocznik Toruński” 2002, t. 29, s. 49-85.

Partyka J., Szlachecka silva rerum jako źródło do badań etnograficznych, „Etnografia Polska” 1988, t. 32, z. 2, s. 67-91.

Próchniak P., Człowiek wobec zagrożeń pogodowych: konfrontacja i prewencja, Toruń 2014.

Przybylak R., Pospieszyńska A., Air Temperature in Wroctaw (Breslau) in the period 1710-1721 based on Measurements made by David von Grebner, „Acta Agrophysica. Meteorology and Climatology Research" 2010, t. 5, nr 184, s. 35-43.

Przybylak R., Pospieszyńska A., Charakterystyka hydrometeorów w Toruniu w okresie 1760-1764, w: Rozwój zrównoważony regionów Polski, red. W. Wysota, Toruń 2011, s. 157-165.

Przybylak R., Pospieszyńska A., Temperatura powietrza $w$ Toruniu $w$ okresie 1760-1764, w: Klimat Polski na tle klimatu Europy. Warunki termiczne i opadowe, red. E. Bednorz, Poznań 2010, s. 53-66.

Przybylak R., Wójcik G., Marciniak K., Chorążyczewski W., Nowosad W., Oliński P., Syta K., Zmienność warunków termiczno-opadowych $w$ Polsce w okresie 1501-1840 w świetle danych historycznych, „Przegląd Geograficzny” 2004, t. 76, z. 1, s. 5-31.

Roćko A., Rzeczpospolita czasów saskich w pamiętniku Krzysztofa Zawiszy - świat wojen, żywiołów, niepokojów, „Napis” 2001, seria VII, s. 313-321.

Rok B., Kalendarze polskie czasów saskich, Wrocław 1985.

Rokicka M., Gazety ulotne o klęskach żywiołowych - o wariantywności ich schematu kompozycyjnego, w: Staropolskie teksty i konteksty. Studia, t. 4, red. J. Malicki, D. Rott, Katowice 2003, s. 30-43.

Sander H., Owady, Warszawa 1989.

Semkowicz W., Zagadnienie klimatu w czasach historycznych, „Przegląd Geograficzny” 1922 [1923], t. 3, s. $18-42$.

Słownik Geograficzny Królestwa Polskiego i innych krajów słowiańskich, red. F. Sulimierski, B. Chlebowski, W. Walewski, J. Krzywicki, t. 1-15, Warszawa 1880-1902.

Słownik meteorologiczny, red. T. Niedźwiedź, Warszawa 2003.

Słownik stereotypów i symboli ludowych, red. J. Bartmiński, t. 1: Kosmos, cz. 1: Niebo, światła niebieskie, ogień, kamienie, Lublin 1996, cz. 3: Meteorologia, Lublin 2012.

Smoleński W., Wiara $w$ życiu społeczeństwa polskiego $w$ epoce jezuickiej. Studyum historyczne, w: Ognisko. Ksiązka zbiorowa wydana dla uczczenia 25 letniej pracy T.T. Jeża, Warszawa 1882, s. 205-256.

Sołtys W., Klęski elementarne w ziemi sanockiej $w$ XVII w. i ich wplyw na życie mieszkańców, „Materiały Muzeum Budownictwa Ludowego w Sanoku” 1984, nr 28, s. 56-75.

Srogosz T., Staropolskie postrzeganie klesk elementarnych, w: Staropolski ogląd świata: materiały z konferencji, Wrocław 23-24 października 2004 r., red. B. Rok, F. Wolański, Wrocław 2004, s. 151-158.

Stamm E., Miary długości $w$ dawnej Polsce, Warszawa 1935.

Stamm E., Miary długości w dawnej Polsce, Warszawa 1935.

Staszewski J., August III Sas, Wrocław 1989.

Stenz E., Korespondencja Państwowego Instytutu Meteorologicznego. Ciekawe skojarzenie zjawisk halo, „Wiadomości Meteorologiczne” 1924, nr 3/4, s. 58-59.

Stenz E., O obserwacjach zjawisk halo, „Wiadomości Meteorologiczne” 1922, nr 4/5, s. 37-39.

Stenz E., O zjawiskach halo (cześć I), „Wiadomości Meteorologiczne” 1922, nr 2, s. 16-17. 
Stenz E., Ziemia. Fizyka globu, mórz i atmosfery, Warszawa 1936.

Stenz E., Zjawiska optyczne w atmosferze, Łódź 1950.

Stenz E., Zorze polarne, „Przyroda i Technika”, V 1929, z. 5, s. 204-213.

Szymocha M., Kiedy niebo zapłonie, „Wiedza i Życie” 2005, nr 7, s. 674-687.

The Polish Climate in the European Context An Historical Overview, red. R. Przybylak, J. Majorowicz, R. Brázdil, M. Kejna, Berlin-Heidelberg-New York 2010.

Trojan P., Bioklimatologia ekologiczna, Warszawa 1985.

Urzędnicy Wielkiego Księstwa Litewskiego. Spisy, t. 1: Województwo wileńskie XIV-XVIII wiek, red. A. Rachuba, oprac. H. Lulewicz, A. Rachuba, P.P. Romaniuk, współpraca U. Jemialianczuk, A. Macuk, Warszawa 2004.

Walawender A., Kronika klęsk elementarnych $w$ Polsce i $w$ krajach sąsiednich $w$ latach 1450-1586, t. 1: Zjawiska meteorologiczne i pomory (z wykresami), Lwów 1932.

Wójcik M.L., Chwile strachu i trwogi. Klęski żywiołowe, konflikty zbrojne i tumulty w średniowiecznym Wrocławiu, Racibórz 2008.

Wyjątki ze źródet historycznych o nadzwyczajnych zjawiskach hydrologiczno-meteorologicznych na ziemiach polskich $w$ wiekach od $X$ do XVI, wybór, przeł. R. Girguś, W. Strupczewski, red. A. Rojecki, Warszawa 1965.

Yeomans D.K., Komety od starożytności do wspótczesności, w mitach, legendach i nauce, przeł. A.S. Pilski, Warszawa 1999.

Zajęcki M., Instrumenty prawne ochrony przeciwpożarowej w miastach Polski przedrozbiorowej, Poznań 2014.

Michał Tomasz Wójciuk - mgr, historyk i archiwista; doktorant w Instytucie Historii Uniwersytetu Marii Curie-Skłodowskiej w Lublinie, specjalista w Dziale Historycznym Muzeum Powstania Warszawskiego. Prowadzi badania nad problematyką życia codziennego w Rzeczypospolitej epoki saskiej. Zajmuje się również niektórymi zagadnieniami historii najnowszej. Autor ponad 40 publikacji naukowych i popularnonaukowych, współautor 12 wystaw historycznych.

E-mail:mwojciuk@poczta.onet.pl 